เ 4 … - 1-2243

\title{
Corrosion Evaluation of Underground Telephone Cable Shielding Materials
}

W. F. Gerhold and J. L. Fink

Chemical Stability and Corrosion Division

Center for Materials Science

U.S. Department of Commerce

National 3ureau of Standards

Washington, DC 20234

April 1981

Progress Report

$197 €-1980$

Frepared for

Rural Electrification Administration

$-Q C-$ irtment of Agriculture
100
.456
$81-2243$
1981




\section{CORROSION EVALUATION OF UNDERGROUND TELEPHONE CABLE SHIELDING MATERIALS}

W. F. Gerhold and J. L. Fink

Chemical Stability and Corrosion Division

Center for Materials Science

U.S. Department of Commerce

National Bureau of Standards

Washington, DC 20234

April 1981

Progress Report

1976-1980

DISTRIBUTION OF THIS DOCUMENT IS UNLIMITED

Prepared for

Rural Electrification Administration

Department of Agriculture

Washington, DC 20250

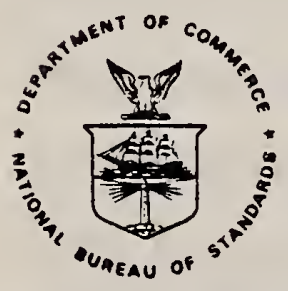

U.S. DEPARTMENT OF COMMERCE, Malcolm Baldrige, Secretary NATIONAL BUREAU OF STANDARDS, Ernest Ambler, Director 

CORROSION EVALUATION OF UNDERGROUND TELEPHONE CABLE SHIELDING MATERIALS

William F. Gerhold and James L. Fink

Corrosion and Electrodeposition Group

Chemical Stability and Corrosion Division

National Bureau of Standards

Washington, DC 20234

\section{INTRODUCTION}

An increase in underground telephone cable installation by the telephone industry throughout the United States has created a demand for comprehensive and reliable information with respect to the corrosion of shielding materials. In order to obtain such corrosion data on both currently accepted and proposed experimental cable systems, the National Bureau of Standards and the Rural Electrification Administration initiated a six-year underground corrosion program. The program was initiated in 1968 with the burial of thirty-one cable systems in selected soil environments. A paper summarizing the results for specimens buried for one year was given at the 18th International Wire and Cable Symposium [1]. During the period since the first report and the present time, many additional systems utilizing metals or plastic coated metals have been incorporated into the program. Other papers were presented at the Corrosion/74 [2] and Corrosion/76 Symposia [3] summarizing the results obtained for these materials and the additional systems after burial for periods of up to six years in soil environments. This paper (the fourth report) contains additional data for some of the systems included in the earlier reports and results obtained for systems buried over the years since the last report. Table 1 describes the various cable systems included in this report. 


\section{SOILS AT THE TEST SITES}

The chemical and physical properties of the soils at the test sites are given in table 2. The chemical properties listed show that the soils differ widely with respect to their composition and the concentrations of soluble salts they contain. The $\mathrm{pH}$ of the soils range from extreme acidity (4.0) to high alkalinity (8.8). The electrical resistivity of the soils range from $55 \mathrm{ohm}-\mathrm{cm}$, which is approximately that of sea water, to $30,000 \mathrm{ohm}-\mathrm{cm}$, indicating the absence of soluble salts. The physical conditions of the soils range from wel1 aerated to very poorly aerated.

These widely differing soil environments allow for a comprehensive soil corrosion program. The soils included are moderately corrosive (Sites B and D) to very corrosive (Sites A, C, E, and G) toward ferrous and other metals. The soils cover a wide range of soil properties, with respect to corrosion, found throughout the United States. Furthermore, it is possible to correlate corrosion data from these six soils with data previously obtained from 128 test sites in which the National Bureau of Standards has conducted extensive investigations on the underground corrosion of metals and alloys [3]. Descriptions of the soils at the six test sites are as follows:

Sagemoor sandy loam (Site A) is a well-drained alkaline soil and is typical of that found in vast areas of eastern Washington and Oregon. The site is located on the Yakima Indian Reservation near Toppenish, Washington. The soil is consistent in composition to a depth of at least seven feet and supports abundant growth of sage brush.

Hagerstown loam (Site B) is a well-drained soil representative of the majority of well-developed soils found in the eastern part of the United States. The site is located at the Loch Raven Reservoir of the Baltimore City 
Water Department. The soil consists of a brown loam about one foot deep, underlain by a reddish-brown clay that extends five feet or more to underlying rock. Practically all of the materials that have been investigated in the extensive NBS soil corrosion tests since 1922 have been exposed at this site and, therefore, it can serve as a reference site for the correlation of data obtained for specimens in the present program with data obtained from the earlier tests.

Clay soil (Site C). This site is located in a large clay pit on level land at the U.S. Coast Guard Receiving Center at Cape May, New Jersey. The soil consists of a plastic gray clay to a depth of twelve inches. This is underlain by a poorly drained very heavy plastic clay to which the specimens are exposed.

Lakewood sand (Site D) is a white, loose sand with some black streaks occurring in places and supports an abundant growth of beach grasses. The site is located in a well-drained rolling area on the property of the U.S. Coast Guard Electronic Engineering Station at Wildwood, New Jersey. The area is not subject to overflow from the ocean except under unusual flood conditions.

Coastal sand (Site E) is a typical white, coastal beach sand with a high content of black sand that occurs in streaks. This sand is similar to Lakewood sand, except that at this site, the sand is continuously saturated with salt water. The site is located on the Two-mile Beach on the property of the U.S. Coast Guard Electronic Engineering Station, Wildwood, New Jersey. 
Tidal marsh (Site G) is a soil typical of the poorly-drained marsh soils that are found along the Atlantic and Gulf coasts and is charged with hydrogen sulfide. The site is located along a creek that empties into the Chesapeake Bay at Lexington Park, Maryland, on the property of the U.S. Naval Air Training Center.

\section{TEST PROCEDURE}

In order to expose the shield material to the environment and to simulate conditions which may occur in field installations of telephone cables, specimens were prepared as shown in figure 1 . Specimens used in this study were polyethylene jacketed cable lengths [approximately fourteen inches $(35.6 \mathrm{~cm}$ ) long] containing metallic or plastic coated metal shields. With a few exceptions, the shield was exposed by stripping the outer polyethylene protective jacket at two areas, one each approximately four inches (10.2 $\mathrm{cm}$ ) from either end of the cable length, creating a window and a ring. The window was an exposed area along the length of the cable approximately two inches $(5 \mathrm{~cm})$ long $\times 0.5$ inch $(1.3 \mathrm{~cm})$ wide, while the ring was an exposed area 0.5 inch $(1.3 \mathrm{~cm})$ wide around the circumference of the cable. In addition, some of the systems were electrically coupled to copper strips by mechanically bonding the strip to electrical wires which were in turn mechanically bonded to the shield at the ends of the cable. Coupling the shield to copper thus created a galvanic cell between the copper and the shield material. This was done to simulate field conditions in which dissimilar metal shields may be coupled either to existing cable systems having copper shields or to copper ground rods. The ends of the specimens were sealed with a sealing compound and wrapped with vinyl tape to prevent entry of moisture at the end areas. 
With a few exceptions six specimens of each system were buried at each of the six soil sites. All specimens were buried at a depth of approximately three to four feet $(0.9$ to $1.2 \mathrm{~m})$ below the ground line in trenches two feet $(0.6 \mathrm{~m})$ wide.

Each year a replicate specimen was withdrawn from each of the burial sites for cleaning and examination.

Five areas on each of the specimens were examined and rated numerically in accordance with table 3 . These areas were the exposed window, the exposed ring, the jacketed area one-half inch around the exposed window, the jacketed area one-half inch around the exposed ring, and the remainder of the jacketed shield. In the case of composite and clad materials, the outer, middle, and inner shields were rated individually.

\section{RESULTS}

The results obtained from the evaluation of cable specimens exposed for periods up to six years in various underground soil environments are summarized in tables 4 through 9. As previously noted, areas of the shields were given numerical ratings to indicate the extent of degradation due to corrosion. These ratings are described in table 3 . A rating of ten indicates that the shield was unaffected by corrosion, while a rating of zero indicates severe corrosion, where metal loss through corrosion was sufficient to cause longitudinal electrical discontinuity (ELD) of the shield. When the shield exhibited ELD at all areas measured, it was considered to be destroyed. It was noted that degradation of some specimens exposed for shorter periods of time was much more severe than that observed on similar specimens exposed for greater periods of time. This may be partially explained by the methods used in preparation of the specimens. If the cut through the outer jacket 
made to expose the window and ring was deep enough to penetrate the shield, it could allow corrosion of the inner shield materials. On the other hand, if the depth of cut was such that only the outer jacket was slit, then the integrity of the shield materials could be maintained. The following describes the various systems and their performance in the six soil environments in which the specimens were exposed.

System 41. This system consisted of a 25-pair, 22-gauge cable having an uncorrugated 8-mil 1100 aluminum alloy shield. This was a filled cable (polyethylene, 15 percent petroleum jelly, 85 percent by volume in conductor interstices and on both sides of the shield).

In general, the filling compound was tacky except at areas where the cable was corroded.

Specimens of this system were buried at Sites $A, C$, and $G$ only.

There was no significant degradation of the shields of specimens exposed for up to six years at Site $A$. The shields of specimens of this system exposed at Site $C$ were ELD after exposure for three years, while for those buried at Site $G$ the shield was perforated due to corrosion in less than one year and were considered destroyed on specimens buried for four to six years.

System 42 . This system is the same as System 41 except that the shield was coupled to copper.

Specimens of this system were also buried only at Sites $A, C$, and $G$. Coupling the specimens to copper accelerated the corrosion of the shields.

After exposure for one year at Site $A$, the shield was ELD at several areas. Examination of specimens retrieved from this site after exposure for two to six years revealed that all were ELD at all areas rated. Specimens exposed at Sites $C$ and $G$ for up to six years were also ELD at all areas rated. 
System 43. This system consisted of a 100-pair, 19-gauge cable having an 8-mil corrugated 1100 aluminum alloy inner and outer shield with a polyethylene jacket bonded to the inner sides of both shields.

Specimens were exposed at Sites $A, C$, and $G$ only.

The outer and inner shields of specimens exposed for up to six years at Site $A$ were not significantly affected by corrosion.

After exposure for two and three years at Sites $C$ and $G$ both shields were ELD at window and/or ring areas. The outer shields were ELD or near ELD at jacketed areas on specimens buried at these sites for two to six years. The inner shields of specimens buried for four to six years were unaffected by corrosion.

System 44 . This system was the same as System 43 except that the system was coupled to copper.

Corrosion of the aluminum shields was accelerated due to the galvanic effect between the copper and aluminum.

The outer aluminum shields were ELD or near ELD on all specimens exposed at Sites $A, C$, and $G$ for up to six years. With one exception the inner shields of these specimens at jacketed areas were relatively unaffected by corrosion. The inner shield of the specimen buried at Site $A$ for five years was perforated due to localized pitting corrosion. The outer and inner shields of specimens exposed for up to three years at these sites were severely corroded at the exposed window and ring. Most were ELD at these areas.

System 45. This system consisted of a 100-pair, 22-gauge cable. The shield was 8-mil uncorrugated 1100 aluminum alloy, coated with resin on both sides and was bonded to the jacket. 
Specimens of this system were buried at Sites $A, C$, and $G$ only.

The shields of specimens buried for up to six years at Site $A$ were unaffected by corrosion. Specimens buried at Site G were severely corroded at jacketed and unjacketed areas after exposure for one year. After exposure for three years, the shield was ELD or near ELD at jacketed and unjacketed areas. The shields of the specimens exposed for five and six years was ELD at all areas rated.

Corrosion of the specimens buried for up to three years at Site $C$ was less severe but the shields were perforated by corrosion at several areas. After exposure for four to six years, the shields were ELD or near ELD at jacketed and unjacketed areas.

System 46. This system is the same as System 45 except that the shield was coupled to copper.

Specimens of this system were exposed at Sites A, C, and G only.

Coupling the specimens to copper accelerated the corrosion of the aluminum shield in all of the soils.

The shield of the specimen buried for one year at Site $A$ was perforated at window and ring areas due to localized pitting corrosion. Examination of specimens exposed for from two to six years showed that a11 were ELD at a11 areas rated.

Specimens at Sites $C$ and $G$ were severely corroded at jacketed and unjacketed areas. The shields of the specimens buried for four and five years at Site $C$ were ELD at all areas rated, while the specimen buried for six years at this site was near ELD at all areas rated. The shields of specimens of this system buried at Site $G$ for one, three, and four years were perforated by corrosion at all areas rated. The shields on companion specimens buried for two, five, and six years were considered destroyed. 
System 47. This system consisted of a 3-mil corrugated Type 304 stainless steel outer shield bonded to a 6-mil corrugated aluminum inner shield which was vinyl coated on both sides.

Delamination of the outer and inner shields particularly at the edge seam was observed on most of the specimens exposed to the various soil environments.

With a few exceptions, the outer stainless steel shield of specimens exposed for up to six years at all sites was unaffected by corrosion. Pitting corrosion of both shields was observed at the exposed window on the specimen buried for one year at Site $C$. Both shields were perforated by corrosion on specimens buried for one and two years at Site G. With the exception of some specimens buried at Sites $B$ and $D$, the inner aluminum shields were affected by corrosion in varying degrees particularly at window and ring areas. This is attributed to penetration by moisture at the seam edges.

The inner shields on specimens exposed at site $A$ for up to five years were severely corroded at the exposed window. After exposure for two years the shield was near ELD and after exposure for four years the shield was ELD. The inner shield of the specimen exposed for six years was perforated due to localized pitting corrosion at all areas rated.

Localized pitting corrosion with subsequent perforation of the inner shield was noted at unjacketed ring areas of the specimen exposed at site $B$ for one year and at jacketed window areas of the specimen buried at this site for two years.

The inner shields of specimens buried at Site $C$ for two and three years were severely corroded at the exposed window. After exposure for three and five years the shield was near ELD at this area. There was no corrosion of 
the inner shield at jacketed areas on specimens buried for two and three years, while the shields of specimens buried from four to six years were perforated due to localized pitting corrosion at these areas.

The inner shields of specimens buried for up to three years at site 0 and up to two years at Site $E$ were relatively unaffected by corrosion. After exposure for four and six years at these sites the shields were perforated by localized pitting corrosion at all areas rated.

The inner shields of specimens exposed for two years at Site $G$ were ELD at jacketed and unjacketed window areas. After exposure for up to six years the shield was ELD or near ELD at all areas rated.

System 48 . This system is the same as System 47 except that the system was coupled to copper.

As noted for System 47 delamination of the outer and inner shields at edge seam areas was also observed on most specimens of this system.

There was no significant corrosion of the outer stainless steel shield on specimens exposed for up to six years at sites $A, B, C, D$, and $E$. The outer shields of specimens exposed for one and three years at Site $G$ were perforated at window areas due to localized pitting corrosion. The shields were ELD at these areas on specimens buried at this site for two and four years.

With the exception of some of the specimens exposed at Sites B, D, and $E$, the inner aluminum shields were affected in varying degrees by corrosion. After exposure for three and four years, the inner shield was perforated due to localized corrosion at unjacketed window and/or ring areas of specimens buried at Site $B$ and at jacketed and unjacketed areas on specimens buried at Site $D$. The inner shield of the specimens buried for four years at Site $E$ was severely corroded at the unjacketed window and at the jacketed ring. 
The inner shields of companion specimens buried for five and six years at this site were ELD at the unjacketed windows. The inner shields of the specimens buried for three and five years at Site $A$ were ELD at the exposed window, while at the exposed ring, jacketed window and ring areas, corrosion was less severe. The shield of a companion specimen exposed for four years at this site was perforated due to localized pitting corrosion at unjacketed areas but was unaffected by corrosion at jacketed areas. The inner shield of the specimen buried for six years was ELD at the jacketed area.

After exposure for two years at site $C$ the inner shield was ELD at the jacketed window and ring areas. Corrosion of the inner shield of a companion specimen buried for six years was ELD at jacketed and unjacketed areas.

The inner shields of specimens buried for two to six years at site $G$ were ELD or severely corroded at all areas rated.

System 49. This system consisted of a 3-mil corrugated Type 304 stainless steel outer shield bonded to a 4-mil corrugated 1100 aluminum alloy inner shield which was vinyl coated on both sides.

The outer and inner shields had delaminated at the edge seam on nearly al1 specimens.

The specimens buried for up to four years at Site $B$ were unaffected by corrosion.

The outer stainless steel shields were unaffected by corrosion after exposure for two years at Site $G$ and up to six years at Sites $A, C, D$, and E. The outer shield on specimens buried for three, four, and six years at Site $G$ were severely corroded at the window areas. There was no apparent corrosion of the inner shields of specimens exposed for one year at Sites $A$, $B$, and $C$, up to two years at sites $D$ and $E$, and up to six years at Site $B$. 
The inner shields of specimens buried for two to six years at Sites $A$ and $C$ were perforated at exposed window and/or ring areas. After exposure for six years the shields of specimens exposed at these sites were perforated by corrosion and were ELD at the exposed window areas.

The inner shields or specimens exposed at Site $D$ for three to six years were perforated at window and ring areas due to localized pitting corrosion. The shields of these specimens at other jacketed areas were unaffected by corrosion.

After exposure for six years at site $E$, the inner aluminum shield was perforated at all areas rated.

Of the specimens exposed at site $G$ for two to six years, the inner shields were ELD at jacketed and unjacketed areas.

System 50. This system is the same as System 49 except that the system was coupled to copper.

The outer and inner shields of most specimens were found to be delaminated after exposure in the various soils.

With one exception, the outer stainless steel shield was relatively unaffected by corrosion after exposure up to six years at sites $A, B, C, D$, and $E$. The outer shield was perforated due to localized pitting corrosion at the unjacketed window on the specimen exposed for four years at site $C$. Of the specimens exposed for up to six years at Site $G$, the outer shields were, with a few exceptions, perforated due to localized pitting corrosion.

The inner aluminum shields of specimens buried for two years at site $A$, one to five years at Site $B$, and one and two years at Sites $D$ and $E$ were unaffected by corrosion. The inner shields of specimens exposed at site $A$ for three and four years were perforated by corrosion which was more severe at window and ring areas. After exposure for four and six years, the inner 
shield was ELD at the exposed window. The inner shield was near ELD at the window on the specimens exposed for up to three years at site $C$. After exposure for four to six years at this site, the inner shields were ELD at most of the areas rated. The inner shields of specimens buried for four years at Site $D$ and three years at Site $E$ were near ELD at the exposed windows. After exposure for four years at Sites $D$ and $E$, this shield was perforated due to localized pitting corrosion at all areas rated. The inner shields on specimens exposed for up to six years at Site G were in general ELD or near ELD at jacketed and unjacketed areas.

System 51. This system is the same as System 47 except that the adhesive used to bond the outer and inner shield was an epoxy base compound.

The outer and inner shields of nearly all specimens buried in the various soils were delaminated.

With a few exceptions the outer shields of the specimens exposed at Sites $A, B, C, D$, and $E$ were unaffected by corrosion. Of the specimens exposed at Site $G$, the outer shields were perforated due to localized pitting corrosion which occurred generally at the unjacketed window.

The inner shields were ELD or near ELD at the exposed window for two to four years at site $A$. Of the specimens buried for up to six years at Site $C$ most were ELD or near ELD at both jacketed and unjacketed areas. The inner shields on specimens buried at site $D$ for three to six years, and Site $E$ for two to six years were with a few exceptions perforated due to localized pitting corrosion which was observed at jacketed and unjacketed areas. In general, the inner shield on specimens buried at Site $G$ was ELD at all areas rated after exposure for one year.

System 52. This system is the same as System 51 except that the system was coupled to copper. 
Delamination of the outer and inner shields was noted on nearly all specimens examined.

The outer shields of specimens exposed for up to four years at Sites A, $B, C, D$, and $E$ were, with one exception, unaffected by corrosion. The shield on the specimen buried for four years at site $B$ was perforated due to corrosion at the unjacketed window and the jacketed ring.

In general varying degrees of corrosion were observed on the inner shield on all specimens after burial for up to six years in the soils. However, there was no corrosion observed on specimens buried for one year at Sites $A$ and $D$, and up to two years at Site $B$. The shields were ELD after burial for two years at sites $A, C$, and $G$, and three years at Sites $D$ and $E$.

System 53. This system was a 25-pair, 19-gauge filled cable and consisted of an 8-mil 1100 aluminum alloy shield adhesive bonded on both sides with $1.5 \mathrm{mil}$ polyethylene. There was no window or ring on specimens of this system. The conductors were removed from the cable leaving a hollow shell. Specimens of this system were buried at Sites $A, C, D, E$, and $G$ only. There was no apparent degradation of the shields after exposure in any of the soils for up to five years.

System 54 . This system is the same as System 53 except that the system was coupled to copper. There was no window or ring on specimens of this system. The conductors were removed from the cable leaving a hollow shell.

Specimens of this system were buried at Sites $A, C, D, E$, and $G$ only. This system was unaffected by corrosion after one and two years exposure at any of these sites. With two exceptions there was little or no degradation of the shield after exposure for up to six years. On one specimen buried for three years at Site $C$, the shield was near ELD. The shield of the specimen buried for four years at Site $E$ was perforated due to localized pitting corrosion at the seam areas. 
System 55. This system consisted of a 4 inch $\times 9$ inch $\times 0.008$ inch sheet of 8-mil 1100 aluminum alloy bonded on both sides with 1.5 mil polyethylene.

Specimens of this system were unaffected by corrosion after burial for up to six years at site $E$. The aluminum was perforated by corrosion on specimens exposed for two years at Sites $B, C$, and $G$, four years at Site $D$, and five years at Site $A$.

System 56. This system consisted of a 3-mil Type 430 stainless steel outer shield bonded to a 3-mil 1100 aluminum alloy inner shield with a clear flooding compound on the core side.

Specimens of this system were exposed at Sites A, C, D, E, and G only. Delamination of the outer and inner shields was noted on nearly all of the specimens examined.

There was no degradation of the outer or inner shields on specimens exposed for six years at Site $A$ and five years at Site $D$, or of the outer shield on specimens buried for up to six years at Site $C$ and four years at Site E. The outer shield was ELD or near ELD at the unjacketed window and/or ring on specimens buried for four and six years at site $G$. The inner shields were perforated due to localized corrosion after burial for four and six years at Site $C$ and three and four years at Site $E$. In general the inner shield was ELD or near ELD on specimens exposed for from two to six years at Site $G$.

In general, the filling compound was tacky except at areas on the shields where corrosion was observed. 
System 57. This system is the same as System 56 except that the system was coupled to copper.

Specimens of this system were exposed at Sites $A, C, D, E$, and $G$ only.

As noted for System 56, there was delamination of the outer and inner shields on nearly all specimens examined.

In general there was no degradation of the outer shield on specimens buried for up to six years at Sites A, C, D, and E. Localized pitting corrosion was noted on the outer shield of one specimen exposed for one year at Site A. Two outer shields were perforated due to corrosion at unjacketed window or ring areas on specimens buried at site $C$ for five and six years.

There was no degradation of the inner shield on specimens buried from two to six years at Site $A$ and one year at Site $C$. Of the specimens buried at Site $C$ for three to six years the inner shield was ELD or near ELD at jacketed and unjacketed areas. Similarly, the inner shield of specimens buried at Site $D$ for three and six years and Site $E$ for two and four years were ELD at the unjacketed window.

Both the outer and inner shields were ELD after burial for two years at Site $G$.

The filling compound was tacky except at areas where the shields were corroded.

System 58. This system consisted of a $3-\mathrm{mil}(0.08 \mathrm{~mm})$ Type 304 stainless steel shield with $4-\mathrm{mil}(0.10 \mathrm{~mm})$ vapor deposited aluminum coating on the outer surface.

Specimens of this system were exposed at Sites $A, C, E$, and $G$ oniy. With one exception, degradation of the stainless steel was nil or superficial for specimens buried at Sites $A, C, E$, and $G$ for up to five years. On one specimen buried at Site $G$ for five years the stainless steel shield was perforated due to localized pitting corrosion at the unjacketed window. 
The vapor deposited aluminum was dissipated in varying degrees at all of the sites. At Site $A$ the coating was at or near ELD after exposure for two years and was ELD after exposure for four years. The coating was ELD at Sites $C$ and $G$ after exposure for two years and at site $E$ after exposure for three years.

System 59 . This system is the same as System 58 except that the system was coupled to copper.

Specimens of this system were exposed at Sites $A, C, E$, and $G$ only. With one exception, there was no apparent corrosion of the stainless steel on specimens buried at Sites $A, C$, and $E$. The shield of the specimen buried for five years at Site $C$ was perforated due to corrosion at the unjacketed ring.

Of the specimens buried at Site $G$ corrosion of the stainless steel was noted at both jacketed and unjacketed areas on specimens exposed for four and five years.

Degradation of varied degree of the vapor deposited aluminum was noted on all specimens. The coating was ELD or near ELD at jacketed and/or unjacketed areas after exposure for two years at Sites $A, E$, and $G$, and five years at Site $C$.

System 60 . This system consisted of a 3-mil (0.08 mm) Type 304 stainless steel with $2-\mathrm{mil}(0.05 \mathrm{~mm})$ vapor deposited aluminum coating on the outer and core sides of the shield.

Specimens of this system were buried at Sites $A, C, E$, and $G$ only. There was no apparent corrosion of the stainless steel on any of the specimens buried for up to five years at these sites. 
Degradation of varying degree with respect to the vapor deposited aluminum coating on the outer and inner surfaces of the stainless steel was noted on all specimens buried at these sites. The coating on the inner surface was ELD at jacketed areas on the specimens buried for one year at Sites $A$ and $G$, five years at Site $C$, and four years at Site $E$. Degradation of the coating on the outer surface was negligible on specimens buried for up to five years at Sites A, C, and E. However, the coating on the outer surface was ELD on the specimen buried for three years at Site $G$.

System 61. This system is the same as System 60 except that the system was coupled to copper.

Specimens of this system were buried at Sites $A, C, E$, and $G$ only.

There was no apparent corrosion of the stainless steel on any of the specimens exposed at these sites for up to five years.

Degradation of the vapor deposited aluminum coating was observed on all specimens buried at these sites. The coating on the inner surface of the specimens was ELD at jacketed and/or unjacketed areas on specimens buried for two years at Site $A$ and one year at Sites C, E, and G. Degradation of the coating on the outer surface was negligible on all specimens buried at Sites $C, E$, and $G$ for up to five years. The performance of this coating was poor to very poor at jacketed and/or unjacketed areas of the specimens buried for up to three years at Site $A$. Degradation of the coating was negligible on specimens exposed at this site for four and five years.

System 62. This system consisted of a 50-pair, 22-gauge air core cable having an $8-\mathrm{mil}(0.20 \mathrm{~mm})$ aluminum shield with a copolymer coating on both sides of the shield. There was no window or ring on specimens of this system. The conductors were removed from the cable leaving a hollow she 11 . 
The performance of this system was excellent after exposure for five years at Sites $A$ and $C$ and four years at Site $B$. Degradation was not appreciable for specimens exposed at Site $D$ for up to five years or site $E$ for up to four years. After exposure for two and four years at site $G$, the shield was perforated due to localized pitting corrosion while companion specimens exposed for three years and five years were unaffected by corrosion.

System 63. This system consisted of a 16-pair, 22-gauge cable having an $8-\mathrm{mil}(0.20 \mathrm{~mm})$ uncorrugated aluminum alloy shield bonded both sides to a polyolefin polymer. The shield was bonded to the jacket. There was no window or ring on specimens of this system. The conductors were removed from the cable leaving a hollow shell.

No corrosion was observed on specimens buried for five years at Sites $A$, $B, C$, or $D$, and four years at Site $E$. The shields of specimens buried for one, two, and five years at Site $G$ had perforated due to corrosion while companion specimens buried for one and three years were unaffected by corrosion.

System 64. This system consisted of a 25-pair, 18-gauge cable having an $8-\mathrm{mil}(0.20 \mathrm{~mm})$ uncorrugated aluminum alloy shield bonded both sides to a 2-mil $(0.05 \mathrm{~mm})$ polyolefin polymer. The shield was bonded to the jacket.

Specimens buried for up to five years at Sites $A$ and $D$ and four years at Sites $B$ and $E$ were unaffected by corrosion. Only four specimens were buried at Site $B$ due to a lack of sufficient material to allow for five- and six-year recovery of specimens after exposure. Pitting corrosion which resulted in perforation of the shield was noted on one specimen buried for four years at Site $C$ and on specimens buried for four and five years at Site $G$. Other specimens exposed at these sites were unaffected by corrosion. 
System 65. This system consisted of a 25-pair, 24-gauge cable having an $8-\mathrm{mil}(0.20 \mathrm{~mm})$ uncorrugated aluminum alloy shield bonded both sides to a polyolefin polymer. The shield was bonded to the jacket.

There was no apparent corrosion on specimens of this system after burial for up to five years at Sites $A, B, C, D$, and $G$, and four years at Site $E$.

System 66 . This system is the same as System 65 except that the shield was coupled to copper.

Specimens of this system were unaffected by corrosion after exposure for up to five years at Sites $A, B, C$, and $D$, and four years at site $E$.

System 67. This system consisted of a 4-mil $(0.10 \mathrm{~mm})$ aluminum foil [3 $3 / 4$ in. $\times 8$ in. $(9.52 \mathrm{~cm} \times 20.32 \mathrm{~cm})$ ] coated both sides with a 6-mil $(0.15 \mathrm{~mm})$ ethylene acrylic acid copolymer.

There was no apparent degradation on specimens of this system after exposure for three years at Sites $A, B$, and $D$, and two years at site $C$. (Specimens buried for two years at sites $B$ and $D$ and three years at Site $C$ were not recovered.)

System 68. This system consisted of a 4-mit $(0.10 \mathrm{~mm})$ aluminum foil [3 $3 / 4$ in. $\times 8$ in. $(9.52 \mathrm{~cm} \times 20.32 \mathrm{~cm})]$ coated both sides with a 6-mit $(0.15 \mathrm{~mm})$ polyester film.

Specimens of this system were unaffected by corrosion after exposure for three years at sites $A, B$, and $D$, and two years at site $C$. (The specimen buried for three years at site $C$ was not recovered.)

System 69. This system consisted of a 4-mil $(0.10 \mathrm{~mm})$ aluminum foil [1 $1 / 2$ in. $\times 12$ in. $(3.81 \mathrm{~cm} \times 30.48 \mathrm{~cm})]$ coated both sides with a $5.5 \mathrm{mil}$ $(0.14 \mathrm{~mm})$ polyester film. 
Corrosion of specimens of this system was nil for materials buried for up to three years at Site A, and two years at Sites B, C, and D. (Specimens buried for three years at Sites $B$ and $C$, and one and three years at Site $D$ were not recovered.)

System 70. This system consisted of a 25-pair, 24-gauge cable having a 6-mil (0.15 mm) corrugated copper alloy outer shield (nominal chemical composition: 97.5 percent $\mathrm{Cu}, 2.5$ percent $\mathrm{Fe}, 0.02$ percent $\mathrm{P})$ and an inner shield of $4-\mathrm{mil}(0.10 \mathrm{~mm})$ aluminum alloy coated on both sides with a $5.5-\mathrm{mil}$ $(0.14 \mathrm{~mm})$ polyester film. The outer shield was bonded to the jacket. This was a filled cable having a clear flooding compound.

Corrosion was nil for specimens buried up to two years at site $A$ and three years at Sites $B, C$, and $D$. Severe corrosion was noted on the specimen buried for three years at Site $A$. More than twenty-five percent of the metal shield was dissipated due to corrosion.

The filling compound was still tacky, except at corroded areas.

Systems 71 and 72 were buried plant housings and are not included in this report.

System 73. This system consisted of a 25-pair, 22-gauge cable having a 6-mil ( $0.15 \mathrm{~mm})$ corrugated black plate steel outer shield and an 8-mil $(0.20 \mathrm{~mm})$ corrugated aluminum alloy inner shield coated both sides with a 2-mil $(0.05 \mathrm{~mm})$ ethylene acrylic acid copolymer. This was a filled cable having a clear flooding compound over the core and inner shield and another type of clear flooding compound over the outer shield.

In general, the inner and outer shields of specimens exposed for one year at all sites were unaffected by corrosion. Corrosion of the inner shield was severe at the unjacketed window and ring areas on the specimen buried at 
Site B for two years. The outer shields of the specimens buried at Sites $A, D$, and $G$ for two years, Site $B$ for one year, and Site $C$ for one and two years were severely corroded at unjacketed window and/or ring areas. The specimen buried at Site B was ELD at these areas.

System 74. This system was the same as System 73 except that the shields were coupled to copper.

With a few exceptions, corrosion of the inner shields on specimens buried for up to two years at all of the sites was nil or superficial. The inner shield of the specimen buried for two years at Site $C$ was ELD at the unjacketed window while that of the specimen buried for two years at Site $G$ was ELD at all areas examined.

The filling compound was still tacky except at corroded areas.

System 75. This system consisted of a 25-pair, 22-gauge cable having a $6-\mathrm{mil}(0.15 \mathrm{~mm})$ corrugated steel outer shield, coated both sides with a $2-\mathrm{mil}(0.05 \mathrm{~mm})$ ethylene acrylic acid copolymer and an 8-mil $(0.20 \mathrm{~mm})$ corrugated aluminum alloy inner shield, coated both sides with a 2-mil (0.05 mm) ethylene acrylic acid copolymer. This was a filled cable having a clear flooding compound over the core and inner shield and another type of clear flooding compound over the outer shield.

The inner shield on specimens exposed for up to two years at all sites was unaffected by corrosion. The outer shield on specimens buried at Sites $B$ and $D$ for two years, and Site $E$ for one year was also unaffected by corrosion. Corrosion of the outer shield was observed at the window and ring areas on specimens buried at Sites $A, C$, and $G$ for two years. Corrosion was more severe on the specimen buried at Site $G$ where the exposed window was near ELD. Corrosion of the outer shield was also observed at jacketed areas on the specimens buried at Sites $C$ and $G$. 
The filling compounds were tacky except at areas on the shields where corrosion was observed.

System 76. Same as System 75 except that the shields were coupled to copper. Coupling the shields to copper accelerated the corrosion of the outer shield in all of the soils in which the specimens were exposed. No degradation was observed on the inner shield of any of the specimens buried for up to two years. With one exception the outer shield on all specimens was corroded in varying degrees at unjacketed areas. Corrosion at these areas was most severe on specimens buried at Sites $C$ and $G$. The outer shield of the specimen buried for two years at Site G was ELD at the exposed (unjacketed) window and ring. The outer shield of the specimen buried for one year at Site $A$ was unaffected by corrosion.

The filling compounds were still tacky except at corroded areas. System 77. This system consisted of a 25-pair, 22-gauge cable having a 6-mil $(0.20 \mathrm{~mm})$ corrugated steel outer shield and an $8-\mathrm{mil}(0.20 \mathrm{~mm})$ corrugated aluminum alloy inner shield coated both sides with a 2-mil $(0.05 \mathrm{~mm})$ ethylene acrylic acid copolymer. This was a filled cable having a clear flooding compound over the core and inner shield and another type of clear flooding compound over the outer shield.

The inner shield of specimens of this system were unaffected by corrosion after burial for up to two years in the soil environments. There was no degradation of the outer shield of specimens buried for one year at Sites $A, B$, and C. After exposure for two years, corrosion of the outer shield was nil or superficial at jacketed areas for all specimens. Corrosion of the outer shield was observed at the unjacketed window and ring areas on all of the specimens that had been buried for two years. The specimen 
buried at Site G was ELD at these areas. Localized pitting corrosion was noted at these areas on specimens buried at Sites A, B, C, and D for two years, and Site $E$ for one year.

The filling was still tacky except at areas on the shields where corrosion was observed.

System 78 . Same as System 77 except that the shields were coupled to copper.

Coupling the shields to copper accelerated corrosion of the outer shield in all of the soils and the inner shield at sites $C$ and $G$. The inner shields of specimens buried for two years at Sites $B$ and $D$ were unaffected by corrosion. Corrosion of the inner shield on specimens buried at Sites $C$ and $E$ occurred at the window and/or ring areas. Of the specimens buried at Site $G$, the inner shield was ELD or near ELD at window and ring areas and severely corroded at jacketed areas. In general, severe corrosion was observed on the outer shield at the window and ring areas on all specimens of this system. Of the systems buried for two years, the outer shield of those exposed at Sites B, C, and $G$ was at or near ELD at the unjacketed window and ring areas. Corrosion of the outer shield was severe at the window and ring areas on specimens of this system buried for two years at Sites $A$ and $D$ and one year at Site $E$.

The filling compound was still tacky except at corroded areas.

System 79. This system consisted of a 25-pair, 22-gauge cable having a 6-mil $(0.15 \mathrm{~mm})$ corrugated steel outer shield and an 8-mil $(0.20 \mathrm{~mm})$ corrugated aluminum alloy inner shield. This was a filled cable having a clear flooding compound over the core and inner shield and another type of clear flooding compound over the outer shield. 
Except for the specimens buried at Site G, there was no degradation of the inner shield on any of the specimens buried for up to two years in the soils. Severe corrosion was noted on the inner shield at window and ring areas of the specimens buried for one and two years at Site G. In general, corrosion of the outer shield occurred at or adjacent to unjacketed window and ring areas. The specimen buried at Site $G$ was near ELD at these areas. Superficial degradation of the outer shield was noted at jacketed areas on the specimen buried for two years at Site $B$, while localized pitting corrosion was noted on companion specimens buried for one year at site $E$ and two years at Site $G$.

The filling compounds were tacky at all uncorroded areas of the shields.

System 80. Same as System 79 except that the shields were coupled to copper.

Coupling specimens of this system to coppper accelerated the corrosion of the shields. With a few exceptions there was little or no corrosion on either shield at jacketed areas of specimens buried at Sites A, B, C, D, and $E$. The inner shield was perforated due to corrosion at the jacketed ring and/or window areas on specimens buried for two years at Sites $A$ and C. The outer shield was perforated at unjacketed areas of the window and/or ring on specimens buried for up to two years at all sites. After exposure for one year at Site $G$ the unjacketed window and ring areas were at or near ELD due to corrosion. The specimen buried at this site for two years was ELD due to severe degradation at all areas examined and was considered destroyed.

The filling compounds were still tacky at all uncorroded areas of the shields. 
System 81. This system consisted of a 25-pair, 22gauge cable having a 6-mil $(0.15 \mathrm{~mm})$ corrugated steel outer shield coated both sides with 2-mil $(0.05 \mathrm{~mm})$ ethylene acrylic acid copolymer and an 8-mil $(0.20 \mathrm{~mm})$ corrugated aluminum alloy inner shield coated both sides with 2-mil $(0.05 \mathrm{~mm})$ ethylene acrylic acid copolymer. This was a filled cable with amorphous polypropylene applied over the core, inner shield, and outer shield.

There was no corrosion of the inner shield on specimens of this system buried for up to two years at the six soil test sites. Corrosion of the outer shield in varying degrees was noted at unjacketed window and ring areas of specimens buried for two years at Sites $B, D$, and $G$, and one year at Sites $C$ and $E$.

The filling compound was still tacky except at corroded areas.

System 82. Same as System 81 except that the shields were coupled to copper.

Coupling specimens of this system to copper accelerated corrosion of the outer steel shield in all of the soils at window and ring areas. The inner aluminum shield was unaffected by corrosion at jacketed areas, but was severely corroded at unjacketed window and/or ring areas of the specimens buried for two years at Sites $A$ and $C$. The inner shields of these specimens were ELD or near ELD. The specimen buried for two years at Site G was severely corroded at all areas examined and was considered destroyed.

The filling compound was semi-tacky to dry for all specimens.

System 83. This system consisted of a 25-pair, 22-gauge cable having a 6-mil $(0.15 \mathrm{~mm})$ corrugated steel outer shield coated both sides with 2-mil (0.05 mm) ethylene acrylic acid copolymer and an 8-mil (0.20 mm) corrugated aluminum alloy inner shield coated both sides with ethylene 
acrylic acid copolymer. This was a filled cable with amorphous polypropylene applied over the core, inner shield, and outer shield.

With a few exceptions, specimens of this system were unaffected by corrosion. The outer shield was perforated at the unjacketed ring on one specimen exposed for two years at site $C$, while both shields of companion specimens buried for one and two years at Site $G$ were perforated due to corrosion at unjacketed window and ring areas.

The filling compound was semi tacky to dry for all specimens.

System 84 . Same as System 83 except that the shields were coupled to copper.

Coupling specimens of this system to copper accelerated the corrosion of the outer corrugated steel shield of specimens buried in five of the six soils. There was no degradation of either shield on the specimen buried for two years at site $A$. Corrosion of the outer shield on specimens buried for up to two years was in general observed at unjacketed window and ring areas. One specimen exposed for two years at Site $G$ was ELD at both areas while specimens exposed for two years at sites $B, C$, and $D$ and one year at Site $D$ were perforated due to corrosion at one or both of these areas.

The filling compound was semi tacky to dry for all specimens.

System 85. This consisted of a 25-pair, 22-gauge cable having a 6-mil $(0.15 \mathrm{~mm})$ corrugated steel outer shield and an 8-mil $(0.20 \mathrm{~mm})$ corrugated aluminum alloy shield. This was a filled cable with amorphous polypropylene applied over core, inner shield, and outer shield.

With the exception of specimens buried for one and two years at site $G$, corrosion of the inner aluminum shield was nil. The inner shield of the specimen buried at this site for one year was near ELD at the unjacketed 
ring area. A companion specimen buried for two years at this site was severely corroded at all areas examined and was considered destroyed. Corrosion of the outer corrugated steel shield of specimens buried for up to two years at Site $A$ was nil or negligible. The outer corrugated steel shield of specimens buried at Sites B, C, and D for two years was perforated due to corrosion at unjacketed window and ring areas, while corrosion of the outer shield of the specimen buried for one year at Site $E$ was most severe at the unjacketed ring area only.

The filling compound was semi tacky to dry for all specimens.

System 86 . Same as System 85 except that the shields were coupled to copper.

Coupling specimens of this system to copper accelerated corrosion of the shields particularily at unjacketed areas. The inner corrugated aluminum shield of the specimen buried for two years at Site $C$ was ELD at all areas examined, whille the outer corrugated steel shield was relatively unaffected by corrosion at jacketed areas. Severe corrosion of both shields was noted on specimens buried for up to two years at Site $G$. The inner aluminum shield of the specimen buried for one year at this site was perforated due to corrosion at all areas examined, while corrosion of the outer steel shield at jacketed areas was negligible. At unjacketed window and ring areas of this specimen the outer shield was ELD. Both shields of a companion specimen buried for two years at this site were ELD at all areas examined; this specimen was considered destroyed. Of the specimens buried in the other four soils, the outer shields of all were perforated due to corrosion at unjacketed window and ring areas.

The filling compound was semi tacky to dry for all specimens. 
System 87 . This system consisted of a 25-pair, 22-gauge cable having a 6-mil $(0.15 \mathrm{~mm})$ corrugated black plate steel outer shield and an 8-mil $(0.20 \mathrm{~mm})$ corrugated aluminum alloy inner shield coated both sides with 2-mil $(0.05 \mathrm{~mm})$ ethylene acrylic acid copolymer. This was a filled cable with amorphous polypropylene applied over core, inner shield, and outer shield.

There was no degradation of the corrugated aluminum alloy inner shield of specimens buried for up to two years in five of the six soils. The inner shield of the specimen buried for two years at Site $G$ was perforated by corrosion at all areas examined. However, the inner shield was electrically continuous at these areas. With a few exceptions, corrosion of the corrugated black plate steel outer shield was negligible at jacketed areas. The jacketed outer shield on two specimens of this system, one exposed for two years at Site $D$ and one exposed for one year at Site $E$, were perforated due to pitting corrosion at localized areas remote from the window and ring. The outer shield was ELD at the unjacketed window and ring of the specimen buried for two years at Site $G$, while these areas on the outer shield were perforated due to localized pitting corrosion on specimens buried in the other five soils.

The filling compound was semi tacky to dry for all specimens.

System 88 . Same as System 86 except that the shield were coupled to copper.

Coupling specimens of this system to copper accelerated corrosion of the black plate steel outer shield at window and ring areas in all of the soils in which the specimens were exposed. The performance of the outer shields at these unjacketed areas was in general fair to very poor for 
specimens buried in the six soils. Corrosion of the corrugated aluminum inner shield at jacketed areas was nil for specimens buried for up to two years in four of the six soils. Severe corrosion was noted at the area adjacent to the unjacketed window of the specimen buried at site $C$ for two years. Of the specimens buried at Site $G$ for two years, both shields were ELD at all areas rated. This specimen was considered destroyed.

The filling compound was semi tacky to dry for all specimens.

System 89. This system consisted of a 100-pair, 22-gauge semi-conducting cable having a 5-mil $(0.13 \mathrm{~mm})$ corrugated copper alloy shield and a low density polyethylene jacket.

Corrosion of specimens of this system was nil or negligible in all of the soils after exposure for one year.

System 90. Same as System 89 except that the shield was coupled to copper.

Coupling specimens of this system to copper had no effect on the corrosion behavior of the copper alloy shield.

System 91. This system consisted of a 3-mit (0.09 mm) corrugated 1006 low carbon steel outer shield bonded to a $3-\mathrm{mil}(0.08 \mathrm{~mm})$ corrugated 4022 aluminum alloy inner shield.

There was no appreciable corrosion of either shield at jacketed areas of specimens buried for one year at Sites B, C, and D. The shields of the specimens buried at Sites $B$ and $C$ were perforated due to corrosion at unjacketed window and/or ring areas. Of the specimens exposed at Sites $A$ and $G$, both shields were ELD at all areas examined and these specimens were considered to be destroyed. 
System 92. Same as System 91 except that the shields were coupled to copper.

Specimens of this system were exposed at Sites $A, B$, and $G$ only. Coupling this system to copper accelerated corrosion of both shields. The shields of specimens buried for one year in these three soils were ELD at all areas examined and were considered to be destroyed.

System 93. This system consisted of a 3-mil $(0.08 \mathrm{~mm})$ corrugated 1006 low carbon steel inner shield bonded to a $3-\mathrm{mil}(0.08 \mathrm{~mm})$ corrugated 4022 aluminum alloy outer shield.

Specimens of this system were exposed at Sites $A, B, C$, $D$, and E only. With one exception there was no appreciable degradation of the outer aluminum alloy shield after exposure for one year at these sites. The outer shield of the specimen exposed for one year at Site A was perforated due to corrosion at all areas examined. However, this shield was still electrically continuous. The inner low carbon steel shield was ELD at all areas rated on all of the specimens buried for one year at Sites B, C, and D. The inner shield of the specimen buried at Site $A$ for one year was ELD at jacketed and unjacketed window and ring areas. At other jacketed areas on this specimen, the inner shield was severely corroded but was electrically continuous.

System 94. Same as System 93 except that the shields were coupled to copper. Specimens of this system were exposed at Sites A and B only. Coupling specimens of this system to copper accelerated corrosion of both shields. Both the inner and outer shields of the specimens buried for one year at these sites were ELD at all areas examined. These specimens were considered to be destroyed. 


\section{SUMMARY AND DISCUSSION}

The data presented give the performance of various cable systems after exposure for up to six years in different soil environments. Fifty-two (52) different shielding systems (using metal or plastic coated metals) were investigated under some very adverse conditions.

With a few exceptions, direct burial telephone cable specimens containing the various metallic shielding protective systems were fabricated with portions of the outer jackets damaged in order to simulate that which could occur in actual field installations. In addition some of the systems were electrically coupled to copper strips, thus creating a galvanic cell between the copper and the shield materials which were other than copper. This was done to simulate field conditions where the shield may be coupled to existing cable systems having copper shields or to copper ground rods.

Six soil environments were employed which have chemical and physical properties representative of a wide range of soils that may be encountered in the United States in actual field installations. Some are moderately corrosive and some are very corrosive toward ferrous and other metals or alloys.

The data show that of the cable specimens buried for up to six years, few were resistant to corrosion in all of the soils in which they were exposed. 
After exposure for six years in clay, Lakewood sand, and coastal sand environments, and five years in alkaline soil and in tidal marsh, specimens of Systems 53 and 54 were in general unaffected by corrosion. Specimens of these systems were not exposed in Hagerstown loam. System 53 was a filled cable fabricated with a $0.20 \mathrm{~mm}, 1100$ aluminum alloy shield adhesive bonded on both sides with $0.04 \mathrm{~mm}$ polyethylene, while System 54 was the same except that the shield was coupled to copper.

Corrosion was nil or superficial for specimens of Systems 41,43 , and 45 buried for six years in alkaline soil. However, their performance in the acid clay and tidal marsh was very poor. Specimens of these systems were not buried in Hagerstown loam, Lakewood sand, or coastal sand. System 41 was a filled cable fabricated with a $0.20 \mathrm{~mm}$ uncorrugated 1100 aluminum alloy shield, System 43 was a cable fabricated with a $0.20 \mathrm{~mm}$ corrugated 1100 aluminum alloy outer and inner shield with a polyethylene jacket bonded to the innder sides of both shields, while System 45 was a cable fabricated with an uncorrugated 1100 aluminum alloy shield coated with resin on both sides.

Specimens of Systems $47,48,51$, and 52 were relatively unaffected by corrosion after exposure for up to six years in Hagerstown loam. The performance of these systems in the other five soil environments was in general fair to very poor, particularly with respect to the inner shield. System 46 was a cable fabricated with a $0.08 \mathrm{~mm}$ corrugated Type 304 stainless steel outer shield bonded with a polyurethane adhesive to a $0.15 \mathrm{~mm}$ corrugated aluminum alloy inner shield which was vinyl coated on both sides. Systems 49 and 51 were the same as System 47 except that the thickness of the inner shield of System 47 was. $0.10 \mathrm{~mm}$ while for System 51 the adhesive used to bond the outer and inner shields was an epoxy based compound. 
After exposure for five years in alkaline soil, clay, and Lakewood sand, and four to five years in Hagerstown loam, there was little or no degradation due to corrosion of specimens of Systems $62,63,64,65$, and 66. Similarly there was no degradation of the shield of specimens of System 65 after exposure for up to five years in tidal marsh. The performance for specimens of Systems 62,63 , and 64 exposed in tidal marsh was in general fair. Specimens of System 66 were not buried in this soil. System 62 was an air core cable fabricated with a $0.20 \mathrm{~mm}$ aluminum shield coated on both sides with a copolymer coating. Systems 63 and 65 were cables fabricated with a $0.20 \mathrm{~mm}$ uncorrugated aluminum alloy shield bonded both sides to a polyolefin polymer. A different material was used to bond the copolymer to the metallic shields on each of these systems. System 64 was a cable fabricated with a $0.20 \mathrm{~mm}$ aluminum alloy shield bonded both sides with a $0.05 \mathrm{~mm}$ polyolefin polymer. System 66 was the same as System 65 except that the shield.was coupled to copper. In addition, the shields of systems 63,64 , 65 , and 66 were bonded to the jacket.

Specimens of Systems 67,68 , and 69 buried for three years in alkaline soil, Hagerstown loam, clay, and Lakewood sand were unaffected by corrosion. These systems were not exposed in coastal sand or tidal marsh. Specimens of these systems were fabricated using $0.10 \mathrm{~mm}$ thick aluminum foil. The foil of System 67 was coated both sides with a $0.15 \mathrm{~mm}$ ethylene acrylic acid copolymer while the foil of System 68 was coated both sides with a $0.15 \mathrm{~mm}$ polyester $\mathrm{film}$ and the foil of System 69 was coated both sides with a $0.14 \mathrm{~mm}$ polyester film.

Of the specimens exposed for two years in alkaline soil, Hagerstown loam, clay, and Lakewood sand, and one year in coastal sand, Systems 75 and 83 were in general unaffected by corrosion. The performance with respect 
to corrosion of System 84 was excellent after exposure for two years in alkaline soil and Hagerstown loam and fair after exposure for two years in clay, Lakewood sand, and coastal sand. Specimens of these systems buried in the tidal marsh were severely corroded. System 75 was a filled cable fabricated with a $0.15 \mathrm{~mm}$ corrugated steel outer shield coated both sides with a $0.05 \mathrm{~mm}$ ethylene acrylic acid copolymer and a $0.20 \mathrm{~mm}$ corrugated aluminum alloy inner shield coated both sides with an ethylene acrylic acid copolymer. System 83 was a filled cable fabricated with a $0.15 \mathrm{~mm}$ corrugated steel outer shield, coated both sides with $0.05 \mathrm{~mm}$ ethylene acrylic acid copolymer and an $0.20 \mathrm{~mm}$ corrugated aluminum alloy inner shield coated both sides with ethylene acrylic acid copolymer. System 84 was the same as System 85 except that the shield was coupled to copper.

The performance of Systems 76 and 77 after exposure for two years was good in alkaline soil and coastal sand, fair in Hagerstown loam, and poor to very poor in clay and tidal marsh. After exposure for one year in coastal sand the performance for System 77 was good while that for System 76 was poor. System 76 was the same as System 75 except that the shield was coupled to copper. System 77 was a filled cable fabricated with a $0.20 \mathrm{~mm}$ corrugated steel outer shield and a $0.20 \mathrm{~mm}$ corrugated aluminum inner shield coated both sides with $0.05 \mathrm{~mm}$ ethylene acrylic acid copolymer. System 79 was in general unaffected by corrosion after exposure for two years in the alkaline soil, but its performance with respect to corrosion was fair in Hagerstown loam and Lakewood sand. This system was a filled cable fabricated with a $0.15 \mathrm{~mm}$ corrugated steel outer shield and a $0.20 \mathrm{~mm}$ corrugated aluminum alloy inner shield. 
After exposure for one year, specimens of Systems 89 and 90 were unaffected by corrosion in five of the six soils. The corrosion behavior for specimens buried at Site $E$ could not be determined due to topographical changes at the site which resulted in the loss of location markers. The performance with respect to corrosion of System 91 after exposure for one year was fair at Site A, good at Site B, and very poor at Site C. Specimens of this system were not exposed in the other soils. System 89 was a semiconducting cable having a $0.13 \mathrm{~mm}$ copper alloy shield and a low density polyethylene jacket. System 90 was the same except that the shield was coupled to copper. System 91 was a cable fabricated with a $0.08 \mathrm{~mm}$ corrugated 1006 low carbon steel outer shield bonded to a $0.08 \mathrm{~mm} 4022$ aluminum alloy inner shield.

The following should not be considered for use because of the relatively poor performance in one or more of the less aggressive soils: Systems No. 55, $58,60,61,73,77,79,81,85,87,91$, and 93 .

When Systems No. $42,44,46,48,50,52,57,59,74,78,80,82,84$, $86,88,92$, and 94 were coupled to copper, their performance was poor to very poor in one or more of the soils. For most of the materials studied in this investigation, the copper strip coupled to the shield caused an appreciable acceleration of corrosion to the shield over that observed when the same material was not coupled to copper. The copper behaved as the cathode in a galvanic cell where the dissimilar metal shield was the anode. The result was dissipation of the shield by sacrificial corrosion in addition to the normal corrosion occurring in the particular soil environment.

Some exceptions to the above were noted where some specimens fabricated with stainless steel shields were coupled to copper, i.e., Systems No. 48 , 50,57 , and 59. For these specimens the copper would be anodic to the 
stainless steel outer shield and cathodic to the inner aluminum shield. It was noted that there was little or no degradation of the copper strips buried in any of the soils; however, some green patina was observed at areas on all of the copper strips. 


PREPARATION OF SPECIMENS
FOR CABLE EXPOSURE TESTS
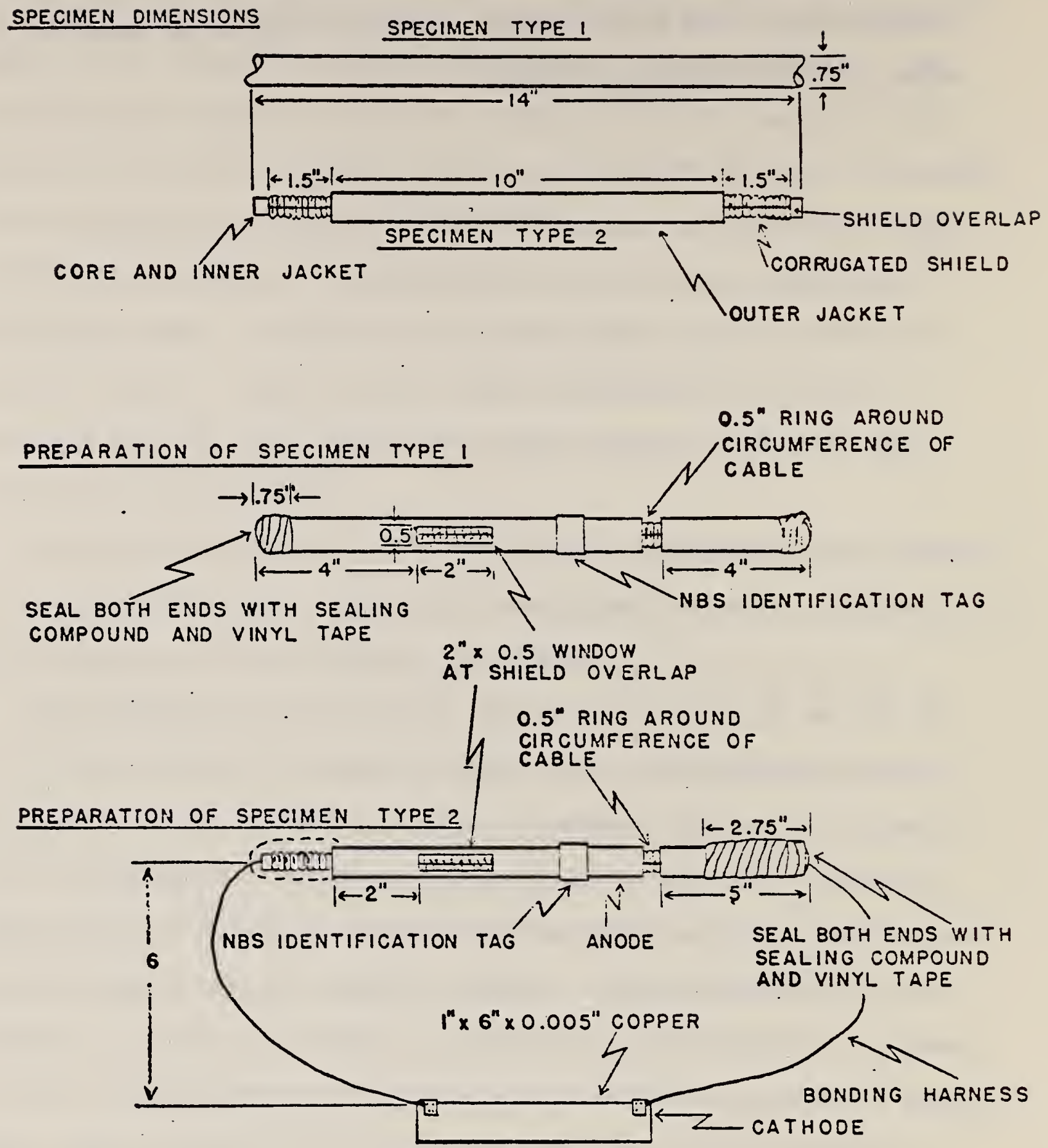

Figure 1 Preparation of specimens for cable exposure tests 
Tables

Table 1 Description of Various Systems Included in the Soil Corrosion Study of Telephone Cable Shielding Materials

Table 2 Properties of the Soils at the Test Sites

Table 3 Rating Code for the Corrosion Evaluation of Shields in Cable Specimens

Table 4 Performance of Shields in Cable Specimens Buried for Up to Six Years in Sagemoor Sandy Loam (Site A)

Table 5 Performance of Shields in Cable Specimens Buried for Up to Six Years in Hagerstown Loam (Site B)

Table 6 Performance of Shields in Cable Specimens Buried for Up to Six Years in Clay Soil (Site C)

Table 7 Performance of Shields in Cable Specimens Buried for Up to Six Years in Lakewood Sand (Site D)

Table 8 Performance of Shields in Cable Specimens Buried for Up to Six Years in Coastal Sand (Site E)

Table 9 Performance of Shields in Cable Specimens Buried for Up to Six Years in Tidal Marsh (Site G) 
Table 1. Description of Various Systems Included in the Soil Corrosion Study of Telephone Cable Shielding Materials.

System ${ }^{1}$ Description

41 25-pair, 22-gauge cable having an 8-mil $(0.20 \mathrm{~mm})$ uncorrugated 1100 aluminum alloy shield. This was a filled cable (polyethylene, 15 percent petroleum jelly, 85 percent by volume in conductor interstices and on both sides of the shield).

42 Same as System 41, except that the shield was coupled to copper.

43 100-pair, 19-gauge cable having an 8-mil $(0.20 \mathrm{~mm})$ corrugated 1100 aluminum alloy inner and outer shield with a polyethylene jacket bonded to the inner sides of both shields.

44 Same as System 43, except that the shield was coupled to copper.

45 100-pair, 22-gauge cable having an 8-mil $(0.20 \mathrm{~mm})$ uncorrugated 1100 aluminum alloy shield coated with resin on both sides. Shield was bonded to the jacket.

Same as System 45, except that the shield was coupled to copper.

47 3-mil (0.08 mm) corrugated Type 304 stainless outer shield bonded with a polyurethane adhesive to a $6-\mathrm{mil}(0.15 \mathrm{~mm})$ corrugated aluminum alloy inner shield which was vinyl coated on both sides.

Same as System 47 , except that the system was coupled to copper.

3-mil $(0.08 \mathrm{~mm})$ corrugated Type 304 stainless steel outer shield bonded to a 4-mil ( $0.10 \mathrm{~mm})$ corrugated 1100 aluminum alloy inner shield which was vinyl coated on both sides.

Same as System 49, except that the system was coupled to copper.

51 Same as System 47, except that the adhesive used to bond the outer and inner shields was an epoxy base compound.

52 Same as System 51, except that the system was coupled to copper.

53 25-pair, 19-gauge filled cable having an 8-mil $(0.20 \mathrm{~mm}) 1100$ aluminum alloy shield adhesive bonded on both sides with 1.5-mil $(0.04 \mathrm{~mm})$ polyethylene.

54 Same as System 53, except that the system was coupled to copper.

$558-\mathrm{mil}(0.20 \mathrm{~mm}) 1100$ aluminum alloy foil $[4 \mathrm{in} . \times 9 \mathrm{in}$. (10.16 cm $x$ $22.86 \mathrm{~cm})]$ bonded both sides with $1.5-\mathrm{mil}(0.04 \mathrm{~mm})$ polyethylene.

56 3-mil $(0.08 \mathrm{~mm})$ Type 430 stainless steel outer shield bonded to a 3-mil $(0.08 \mathrm{~mm}) 1100$ aluminum alloy inner shield with a clear flooding compound on the core side. 
Table 1 (continued)

System ${ }^{1}$

Description

57

Same as System 56, except that the system was coupled to copper.

$583-\mathrm{mil}(0.08 \mathrm{~mm})$ Type 304 stainless steel with $4-\mathrm{mil}(0.10 \mathrm{~mm})$ vapor deposited aluminum on the outer surface.

Same as System 58, except that the shield was coupled to copper.

60

$3-\mathrm{mil}(0.08 \mathrm{~mm})$ Type 304 stainless steel with $2-\mathrm{mil}(0.05 \mathrm{~mm})$ vapor deposited aluminum on the outer and core sides of the shield.

61

Same as System 60, except that the shield was coupled to copper.

62 50-pair, 22-gauge air core cable having an 8-mil (0.20 mm) aluminum alloy shield with a copolymer coating on both sides of the shield. Cable core was removed.

16-pair, 22-gauge cable having an $8-m i 1(0.20 \mathrm{~mm})$ uncorrugazed aluminum alloy shiald bonded both sides to a polyolefin polymer. Shield was bonded to the jacket.

64

25-pair; 18-gauge cable having an 8-mil (0.20 mm) uncorrugated aluminum alloy shield bonded both sides to a 2-mil ( $0.05 \mathrm{~mm}$ ) polyolefin polymer. Shield was bonded to the jacket.

65 25-pair, 24-gauge cable having an 8-mil $(0.20 \mathrm{~mm})$ uncorrugated aluminum alloy shield bonded both sides to a polyolefin polymer. Shield was bonded to the jacket.

66 Same as System 65, except that the shield was coupled to copper.

674 -mil $(0.10 \mathrm{~mm})$ aluminum foi] $[33 / 4 \mathrm{in.} \times 8$ in. $(9.52 \mathrm{~cm} \times 20.32 \mathrm{~cm})]$ coated both sides with a $6-\mathrm{mil}(0.15 \mathrm{~mm})$ ethylene acrylic acid copolymer. coated both sides with a 6-mil $(0.15 \mathrm{~mm})$ polyester film. coated both sides with a $5.5 \mathrm{mil}(0.14 \mathrm{~mm})$ polyester film.

70 25-pair, 24-gauge cable having a 6-mil (0.15 mm) corrugated copper alloy outer shield (nominal chemical composition: 97.5 percent $\mathrm{Cu}$, 2.5 percent $\mathrm{Fe}, 0.02$ percent $P$ ) and an inner shield of 4-mil

$(0.10 \mathrm{~mm})$ aluminum alloy coated on both sides with a $5.5-\mathrm{mi}$ $(0.14 \mathrm{~mm})$ polyester film. Outer shield was bonded to the jacket. This was a filled cable having a clear flooding compound. 
Table 1 (continued)

System ${ }^{1}$

Description

73 25-pair, 22-gauge cable having a 6-mil $(0.15 \mathrm{~mm})$ corrugated black plate steel outer shield and an $8-\mathrm{mil}(0.20 \mathrm{~mm})$ corrugated aluminum alloy inner shield coated both sides with a 2-mil $(0.05 \mathrm{~mm})$ ethylene acrylic acid copolymer. This was a filled cable having a clear flooding compound over the core and inner shield and another type of clear flooding compound over the outer shield.

74 Same as System 73, except that the shields were coupled to copper.

75 25-pair, 22-gauge cable having a 6-mil (0.15 mm) corrugated steel outer shield, coated both sides with a 2-mil $(0.05 \mathrm{~mm})$ ethylene acrylic acid copolymer and an 8-mil $(0.20 \mathrm{~mm})$ corrugated aluminum alloy inner shield, coated both sides with a 2-mil (0.05 mm) ethylene acrylic acid copolymer. This was a filled cable having a clear flooding compound over the core and inner shield and another type of clear flooding compound over the outer shield.

76 Same as System 75, except that the shields were coupled to copper.

77 25-pair, 22-gauge cable having a 6-mil $(0.20 \mathrm{~mm})$ corrugated stee 1 outer shield and an $8-\mathrm{mil}(0.20 \mathrm{~mm})$ corrugated aluminun alloy inner shield coated both sides with a 2-mil $(0.05 \mathrm{~mm})$ ethylene acrylic acid copolymer. This was a filled cable having a clear flooding compound over the core and inner shield and another type of clear flooding compound over the outer shield.

Same as System 77, except that the shields were coupled to copper.

79 25-pair, 22-gauge cable having a 6-mil $(0.15 \mathrm{~mm})$ corrugated steel outer shield and an 8-mil $(0.20 \mathrm{~mm})$ corrugated aluminum alloy inner shield. This was a filled cable having a clear flooding compound over the core and inner shield and another type of clear flooding compound over the outer shield.

Same as System 79, except that the shields were coupled to copper.

81 25-pair, 22-gauge cable having a 6-mil $(0.15 \mathrm{~mm})$ corrugated steel outer shield coated both sides with 2-mil $(0.05 \mathrm{~mm})$ ethylene acrylic acid copolymer and an $8-\mathrm{mil}(0.20 \mathrm{~mm})$ corrugated aluminum alloy inner shield coated both sides with 2-mil ( $0.05 \mathrm{~mm})$ ethylene acrylic acid copolymer. This was a filled cable with amorphous polypropylene applied over the core, inner shield, and outer shield.

82 Same as System 81, except that the shields were coupled to copper.

83 25-pair, 22-gauge cable having a 6-mil (0.15 mm) corrugated steel outer shield coated both sides with 2-mil $(0.05 \mathrm{~mm})$ ethylene acrylic acid copolymer and an 8-mil $(0.20 \mathrm{~mm})$ corrugated aluminum alloy inner shield coated both sides with ethylene acrylic acid copolymer. This was a filled cable with amorphous polypropylene applied over the core, inner shield, and outer shield. 
Table 1 (continued)

84 Same as System 83, except that the shields were coupled to copper.

85 25-pair, 22-gauge cable having a 6-mil $(0.15 \mathrm{~mm})$ corrugated steel outer shield and an $8-\mathrm{mil}(0.20 \mathrm{~mm})$ corrugated aluminum alloy shield. This was a filled cable with amorphous polypropylene applied over core, inner shield, and outer shield.

86 Same as System 85, except that the shields were coupled to copper.

87 25-pair, 22-gauge cable having a 6-mil $(0.15 \mathrm{~mm})$ corrugated black plate steel outer shield and an $8-\mathrm{mil}(0.20 \mathrm{~mm})$ corrugated aluminum alloy inner shield coated both sides with 2-mil $(0.05 \mathrm{~mm})$ ethylene acrylic acid copolymer. This was a filled cable with amorphous polypropylene applied over core, inner shield, and outer shield.

88 Same as System 87, except that the shields were coupled to copper.

89 100-pair, 22-gauge semi-conducting cable having a 5-mil $(0.13 \mathrm{~mm})$ corrugated copper alloy shield and a low density polyethylene jacket.

90 Same as System 89, except that the shield was coupled to copper.

$913-\mathrm{mil}(0.08 \mathrm{~mm})$ corrugated 1006 low carbon steel outer shield bonded to a $3-\mathrm{mil}(0.08 \mathrm{~mm})$ corrugated 4022 aluminum alloy inner shield.

92 Same as System 91, except that the shields were coupled to copper.

$933-\mathrm{mil}(0.08 \mathrm{~mm})$ corrugated 1006 low carbon steel inner shield bonded to a 3-mil $(0.08 \mathrm{~mm})$ corrugated 4022 aluminum alloy outer shield.

94 Same as System 93, except that the shields were coupled to copper.

Systems were fabricated using 6-pair, 19-gauge direct burial cables unless otherwise indicated. 


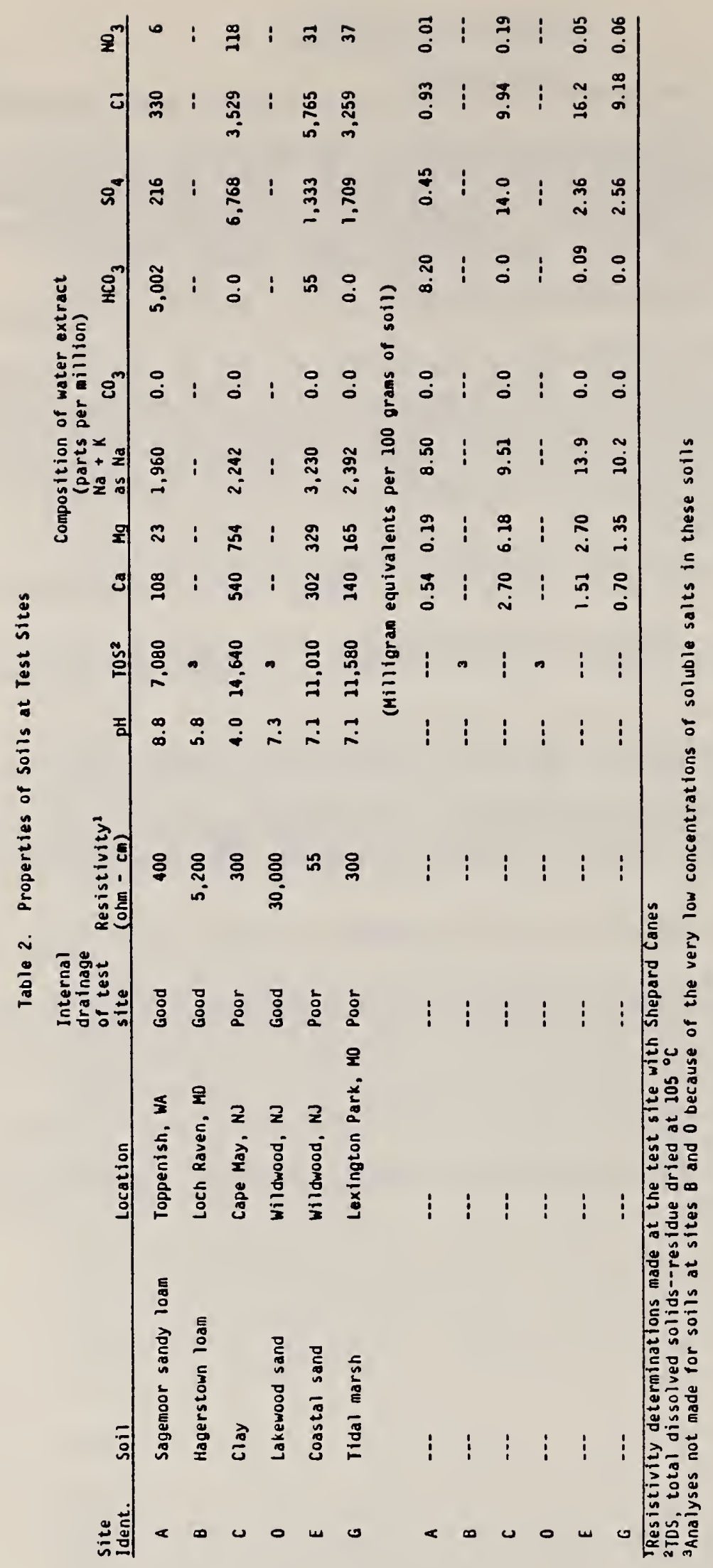


Table 3. Rating Code for the Corrosion Evaluation

of Shields in Cable Specimens

\begin{tabular}{|c|c|c|}
\hline Rating & Performance & Degree of Corrosion \\
\hline 10 & Excellent & Unaffected. No indication of corrosion. \\
\hline 9 & Excellent & Superficial rust or etching on surface. \\
\hline 8 & Very Good & $\begin{array}{l}\text { Uniform metal attack, rust, and/or slight localized } \\
\text { pitting. }\end{array}$ \\
\hline 7 & Good & $\begin{array}{l}\text { Appreciable pitting over the surface, but no perfor- } \\
\text { ations through metal shield. Some minor delamination } \\
\text { or dissipation of metallurgically or plastic-bonded } \\
\text { metals leaving cathodic metal intact. }\end{array}$ \\
\hline $6+$ & Good & $\begin{array}{l}\text { Localized pitting: only one perforation in shield } \\
\text { by pitting. }\end{array}$ \\
\hline 6 & Good & $\begin{array}{l}\text { Localized pitting: two to five perforations in } \\
\text { shield by pitting. }\end{array}$ \\
\hline 5 & Fair & $\begin{array}{l}\text { Many localized pits causing perforation of shield; } \\
<5 \text { percent of shield dissipated by corrosion; } \\
\text { extensive delamination of metallurgically bonded } \\
\text { metals. }\end{array}$ \\
\hline 4 & Poor & $\begin{array}{l}\text { Severe corrosion: pitting to perforation of shield; } \\
\text { five to ten percent of shield dissipated by corrosion; } \\
\text { severe corrosion of anodic part of metallurgically } \\
\text { bonded metals. }\end{array}$ \\
\hline 3 & Poor & $\begin{array}{l}\text { Severe corrosion: pitting to perforation of shield; } \\
\text { ten to twenty-five percent of shield dissipated by } \\
\text { corrosion. }\end{array}$ \\
\hline 2 & Very Poor & $\begin{array}{l}\text { Severe corrosion: more than twenty-five percent of } \\
\text { shield dissipated by corrosion; shield still has } \\
\text { electrical continuity along the cable. }\end{array}$ \\
\hline 1 & Very Poor & $\begin{array}{l}\text { Severe corrosion: shield is close to electrical } \\
\text { discontinuity (ELD) due to perforation in shield and } \\
\text { dissipation of metal by corrosion. }\end{array}$ \\
\hline 0 & Very Poor & $\begin{array}{l}\text { Severe corrosion: shield is electrically discon- } \\
\text { tinuous (ELD) due to dissipation of metal by } \\
\text { corrosion. }\end{array}$ \\
\hline
\end{tabular}


Table 4

Performance of Shields in Cable Specimens Buried Up to Six Years in Sagemoor Sandy Loam (Site A)

\begin{tabular}{ccccccr} 
System & $\begin{array}{c}\text { Exposure } \\
\text { Time } \\
\text { (years) }\end{array}$ & $\begin{array}{c}\text { Exposed } \\
\text { Window }\end{array}$ & $\begin{array}{c}\text { Exposed } \\
\text { Ring }\end{array}$ & $\begin{array}{c}\text { Under } \\
\text { Jacket }\end{array}$ & $\begin{array}{l}1 / 2 \text { Inch } \\
\text { Window }\end{array}$ & $\begin{array}{l}1 / 2 \text { Inch } \\
\text { Ring }\end{array}$ \\
\hline \multirow{2}{*}{41} & 1 & 10 & 10 & 10 & 10 & 10 \\
& 2 & 9 & 9 & 9 & 9 & 9 \\
& 3 & 10 & 10 & 10 & 10 & 10 \\
& 4 & 9 & 9 & 9 & 9 & 9 \\
& 5 & 10 & 10 & 10 & 10 & 10 \\
& 6 & 10 & 10 & 10 & 10 & 10
\end{tabular}

42

$\begin{array}{ll}1 & 5 \\ 2 & \text { Destroyed } \\ 3 & \text { Destroyed } \\ 4 & \text { Destroyed } \\ 5 & \text { Destroyed } \\ 6 & \text { Destroyed }\end{array}$

43

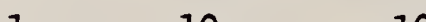

$\begin{array}{lll}1 & 10 & 10 \\ 2 & 10 & 10 \\ 3 & 9 & \\ 4 & 9(10) & 10 \\ 5 & 10 & 10 \\ 6 & 10 & 10\end{array}$

44

1
2
3
4
5
6

45

7

$0 \quad 0$

0

$0(9)$

10

9

10

10
10

4

0

0

10

10

9

9

9

10

10

10

$10 \quad 10$

10

9

10
10

10

10

10

10

10

10

$8(10)$

$8(10)$

$8(10)$

5(10) 7(10)

$0(10) \quad 0(10)$

$0(10)$

$0(10)$

$0(9)$

$0(10)$

$0(10)$
$0(10)$

$0(9)$

$0(9)$

$0(5)$

$0(10)$

$\begin{array}{lc}2(10) & 10 \\ 0(10) & 10 \\ O(10) & 10 \\ O(9) & \text { Missing } \\ O(10) & \text { Missing } \\ O(10) & 5\end{array}$

$\begin{array}{ll}1 & 10 \\ 2 & 10 \\ 3 & 10 \\ 4 & 10 \\ 5 & 10 \\ 6 & 10\end{array}$

$0(10)$

O(10)

10
10
10
10
10
10

10

10

10

10

10

10

10

10

10

10

10

10

10

10

10

10

10

46

$\begin{array}{ll}1 & 4 \\ 2 & \text { Destroyed } \\ 3 & \text { Destroyed } \\ 4 & \text { Destroyed } \\ 5 & \text { Destroyed } \\ 6 & 0\end{array}$

10

5

5

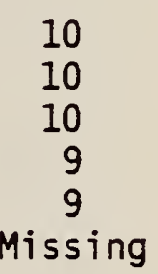


Table 4 (continued)

\begin{tabular}{|c|c|c|c|c|c|c|c|}
\hline System & $\begin{array}{c}\text { Exposure } \\
\text { Time } \\
\text { (years) }\end{array}$ & $\begin{array}{l}\text { Exposed } \\
\text { Window }\end{array}$ & $\begin{array}{l}\text { Exposed } \\
\text { Ring }\end{array}$ & $\begin{array}{l}\text { Under } \\
\text { Jacket }\end{array}$ & $\begin{array}{l}1 / 2 \text { Inch } \\
\text { Window }\end{array}$ & $\begin{array}{l}1 / 2 \text { Inch } \\
\text { Ring }\end{array}$ & $\begin{array}{l}\text { Copper } \\
\text { Cathode }\end{array}$ \\
\hline 47 & $\begin{array}{l}1 \\
2 \\
3 \\
4 \\
5 \\
6\end{array}$ & $\begin{array}{l}10(3) \\
10(1) \\
10(3) \\
10(0) \\
10(2) \\
10(5)\end{array}$ & $\begin{array}{l}10(5) \\
10 \\
10 \\
10(5) \\
10(5) \\
10(5)\end{array}$ & $\begin{array}{l}10 \\
10 \\
10 \\
10 \\
10(5) \\
10(5)\end{array}$ & $\begin{array}{l}10 \\
10(5) \\
10(7) \\
10(5) \\
10(5) \\
10(5)\end{array}$ & $\begin{array}{l}10 \\
10 \\
10 \\
10(9) \\
10(6) \\
10(5)\end{array}$ & \\
\hline 48 & $\begin{array}{l}1 \\
2 \\
3 \\
4 \\
5 \\
6\end{array}$ & $\begin{array}{l}10(2) \\
10(7) \\
10(0) \\
10(4) \\
10(0) \\
10(5)\end{array}$ & $\begin{array}{l}10 \\
10(7) \\
10(5) \\
10(5) \\
10(4) \\
10(5)\end{array}$ & $\begin{array}{l}10 \\
10 \\
10(9) \\
10 \\
10(6) \\
10\end{array}$ & $\begin{array}{l}10 \\
10(4) \\
10(5) \\
10 \\
20(5) \\
10(5)\end{array}$ & $\begin{array}{l}10 \\
10(7) \\
10(5) \\
10 \\
10(5) \\
10(5)\end{array}$ & $\begin{array}{c}10 \\
9 \\
9 \\
9 \\
9 \\
\text { Missing }\end{array}$ \\
\hline 49 & $\begin{array}{l}1 \\
2 \\
3 \\
4 \\
5 \\
6\end{array}$ & $\begin{array}{l}10 \\
10(3) \\
10(5) \\
10(2) \\
10(0) \\
10(0)\end{array}$ & $\begin{array}{l}10 \\
10 \\
10(5) \\
10(5) \\
10(5) \\
10\end{array}$ & $\begin{array}{l}10 \\
10 \\
10(9) \\
10(5) \\
10(5) \\
10(5)\end{array}$ & $\begin{array}{l}10 \\
10 \\
10(9) \\
10(5) \\
10(5) \\
10(5)\end{array}$ & $\begin{array}{l}10 \\
10 \\
10(9) \\
10(5) \\
10(5) \\
10\end{array}$ & \\
\hline 50 & $\begin{array}{l}1 \\
2 \\
3 \\
4 \\
5 \\
6\end{array}$ & $\begin{array}{l}10 \\
10 \\
10(2) \\
10(0) \\
10(5) \\
10(0)\end{array}$ & $\begin{array}{l}10 \\
10 \\
10(5) \\
10(5) \\
10(5) \\
10\end{array}$ & $\begin{array}{l}10 \\
10 \\
10(5) \\
10(5) \\
10(5) \\
10(5)\end{array}$ & $\begin{array}{l}10 \\
10 \\
10(2) \\
10(4) \\
10(5) \\
10\end{array}$ & $\begin{array}{l}10 \\
10 \\
10(5) \\
10(5) \\
10(5) \\
10\end{array}$ & $\begin{array}{r}10 \\
9 \\
9 \\
9 \\
10 \\
9\end{array}$ \\
\hline 51 & $\begin{array}{l}1 \\
2 \\
3 \\
4 \\
5 \\
6\end{array}$ & $\begin{array}{c}9 \\
10(0) \\
10(0) \\
10(1) \\
10(5) \\
10(9)\end{array}$ & $\begin{array}{c}9 \\
10(5) \\
10(5) \\
10(5) \\
10(3) \\
10(9)\end{array}$ & $\begin{array}{l}10 \\
10(5) \\
10(5) \\
10(5) \\
10(7) \\
10(9)\end{array}$ & $\begin{array}{l}10 \\
10(5) \\
10(4) \\
10(5) \\
10 \\
10(9)\end{array}$ & $\begin{array}{l}10 \\
10(5) \\
10(5) \\
10(5) \\
10(5) \\
10(9)\end{array}$ & \\
\hline 52 & $\begin{array}{l}1 \\
2 \\
3 \\
4 \\
5 \\
6\end{array}$ & $\begin{array}{l}10 \\
10(0) \\
10(0) \\
10(5) \\
10(5) \\
10(4)\end{array}$ & $\begin{array}{l}10 \\
10(5) \\
10(0) \\
10(5) \\
10(3) \\
10(4)\end{array}$ & $\begin{array}{l}10 \\
10(0) \\
10(0) \\
10(5) \\
10(5) \\
10(4)\end{array}$ & $\begin{array}{l}10 \\
10(0) \\
10(0) \\
10(5) \\
10 \\
10(4)\end{array}$ & $\begin{array}{l}10 \\
10(5) \\
10(0) \\
10(5) \\
10(5) \\
10(4)\end{array}$ & $\begin{array}{r}9 \\
9 \\
9 \\
10 \\
9 \\
10\end{array}$ \\
\hline 53 & $\begin{array}{l}1 \\
2 \\
3 \\
4 \\
5\end{array}$ & & & $\begin{array}{l}10 \\
10 \\
10 \\
10 \\
10\end{array}$ & . & & \\
\hline
\end{tabular}


Table 4 (continued)

\begin{tabular}{|c|c|c|c|c|c|c|c|}
\hline System & $\begin{array}{c}\text { Exposure } \\
\text { Time } \\
\text { (years) }\end{array}$ & $\begin{array}{l}\text { Exposed } \\
\text { Window }\end{array}$ & $\begin{array}{l}\text { Exposed } \\
\text { Ring }\end{array}$ & $\begin{array}{l}\text { Under } \\
\text { Jacket }\end{array}$ & $\begin{array}{l}1 / 2 \text { Inch } \\
\text { Window }\end{array}$ & $\begin{array}{l}\text { 1/2 Inch } \\
\text { Ring }\end{array}$ & $\begin{array}{l}\text { Copper } \\
\text { Cathod }\end{array}$ \\
\hline 54 & $\begin{array}{l}1 \\
2 \\
3 \\
4 \\
5\end{array}$ & \multicolumn{2}{|c|}{$\begin{array}{l}\text { Not recovered } \\
\text { Not recovered }\end{array}$} & $\begin{array}{l}10 \\
10 \\
10\end{array}$ & & & Missin \\
\hline 55 & $\begin{array}{l}1 \\
2 \\
3 \\
4 \\
5\end{array}$ & \multicolumn{2}{|c|}{$\begin{array}{l}\text { Not recovered } \\
\text { Not recovered }\end{array}$} & $\begin{array}{r}10 \\
10 \\
5\end{array}$ & & & \\
\hline 56 & $\begin{array}{l}1 \\
2 \\
3 \\
4 \\
5 \\
6\end{array}$ & $\begin{array}{l}10 \\
10 \\
10 \\
10 \\
10 \\
10\end{array}$ & $\begin{array}{l}10 \\
10 \\
10 \\
10 \\
10 \\
10\end{array}$ & $\begin{array}{l}10 \\
10 \\
10 \\
10 \\
10 \\
10\end{array}$ & $\begin{array}{l}10 \\
10 \\
10 \\
10 \\
10 \\
10\end{array}$ & $\begin{array}{l}10 \\
10 \\
10 \\
10 \\
10 \\
10\end{array}$ & \\
\hline 57 & $\begin{array}{l}1 \\
2 \\
3 \\
4 \\
5 \\
6\end{array}$ & $\begin{array}{l}10(4) \\
10 \\
10 \\
10 \\
10 \\
10\end{array}$ & $\begin{array}{l}10(5) \\
10 \\
10 \\
10 \\
10 \\
10\end{array}$ & $\begin{array}{l}10 \\
10 \\
10 \\
10 \\
10 \\
10\end{array}$ & $\begin{array}{l}10(5) \\
10 \\
10 \\
10 \\
10 \\
10\end{array}$ & $\begin{array}{l}10(5) \\
10 \\
10 \\
10 \\
10 \\
10\end{array}$ & $\begin{array}{r}10 \\
10 \\
10 \\
10 \\
10 \\
9\end{array}$ \\
\hline
\end{tabular}

58

$\begin{array}{llllll}1 & 9(10) & 9(10) & 8(10) & 9(10) & 9(10) \\ 2 & 8(10 & 0(10) & 2(10) & 2(10) & 1(10) \\ 3 & 9(10) & 9(10) & 8(10) & 9(10) & 9(10) \\ 4 & 0(10) & 0(10) & 0(10) & 0(10) & 0(10) \\ 5 & 8(10) & 8(10) & 5(10) & 8(10) & 8(10)\end{array}$

59

$\begin{array}{rrrlllr}1 & 8(10) & 8(10) & 8(10) & 8(10) & 8(10) & 10 \\ 2 & 0(10) & 4(10) & 0(10) & 0(10) & 5(10) & 9 \\ 3 & 8(10) & 8(10) & 8(10) & 8(10) & 8(10) & 10 \\ 4 & 5(10) & 5(10) & 5(10) & 5(10) & 5(10) & 10 \\ 5 & 8(10) & 8(10) & 8(10) & 8(10) & 8(10) & 10\end{array}$

60

$\begin{array}{rrrrrr}1 & 10(10) 8 & 9(10) 8 & 8(10) 0 & 9(10) 8 & 10(10) 8 \\ 2 & 8(10) 8 & 8(10) 8 & 8(10) 0 & 8(10) 8 & 8(10) 8 \\ 3 & 10(10) 4 & 9(10) 0 & 8(10) 0 & 9(10) 0 & 9(10) 0 \\ 4 & 8(10) 8 & 8(10) 8 & 8(10) 0 & 8(10) 4 & 8(10) 8 \\ 5 & 9(10) 9 & 8(10) 9 & 9(10) 9 & 9(10) 9 & 9(10) 9\end{array}$


Table 4 (continued)

\begin{tabular}{|c|c|c|c|c|c|c|c|}
\hline System & $\begin{array}{c}\text { Exposure } \\
\text { Time } \\
\text { (years) }\end{array}$ & $\begin{array}{l}\text { Exposed } \\
\text { Window }\end{array}$ & $\begin{array}{l}\text { Exposed } \\
\text { Ring }\end{array}$ & $\begin{array}{l}\text { Under } \\
\text { Jacket }\end{array}$ & $\begin{array}{l}1 / 2 \text { Inch } \\
\text { Window }\end{array}$ & $\begin{array}{l}1 / 2 \text { Inch } \\
\text { Ring }\end{array}$ & $\begin{array}{l}\text { Copper } \\
\text { Cathode }\end{array}$ \\
\hline 61 & $\begin{array}{l}1 \\
2 \\
3 \\
4 \\
5\end{array}$ & $\begin{array}{l}2(10) 4 \\
5(10) 5 \\
2(10) 4 \\
8(10) 5 \\
9(10) 0\end{array}$ & $\begin{array}{l}2(10) 8 \\
5(10) 2 \\
8(10) 4 \\
8(10) 8 \\
9(10) 8\end{array}$ & $\begin{array}{l}4(10) 4 \\
5(10) 0 \\
4(10) 0 \\
8(10) 5 \\
9(10) 2\end{array}$ & $\begin{array}{l}2(10) 4 \\
5(10) 5 \\
8(10) 4 \\
8(10) 5 \\
9(10) 8\end{array}$ & $\begin{array}{l}2(10) 8 \\
5(10) 2 \\
8(10) 4 \\
8(10) 5 \\
9(10) 8\end{array}$ & $\begin{array}{r}10 \\
10 \\
10 \\
10 \\
9\end{array}$ \\
\hline 62 & $\begin{array}{l}1 \\
2 \\
3 \\
4 \\
5\end{array}$ & 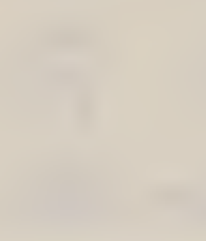 & & $\begin{array}{l}10 \\
10 \\
10 \\
10 \\
10\end{array}$ & & & 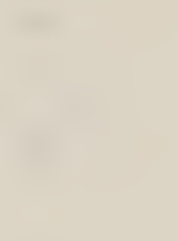 \\
\hline 63 & $\begin{array}{l}1 \\
2 \\
3 \\
4 \\
5\end{array}$ & & & $\begin{array}{l}10 \\
10 \\
10 \\
10 \\
10\end{array}$ & & & \\
\hline 64 & $\begin{array}{l}1 \\
2 \\
3 \\
4 \\
5\end{array}$ & & . & $\begin{array}{l}10 \\
10 \\
10 \\
10 \\
10\end{array}$ & & & 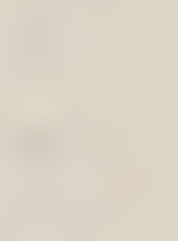 \\
\hline 65 & $\begin{array}{l}1 \\
2 \\
3 \\
4 \\
5\end{array}$ & & 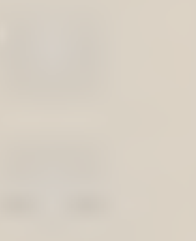 & $\begin{array}{l}10 \\
10 \\
10 \\
10 \\
10\end{array}$ & . & 1 & \\
\hline 66 & $\begin{array}{l}1 \\
2 \\
3 \\
4 \\
5\end{array}$ & 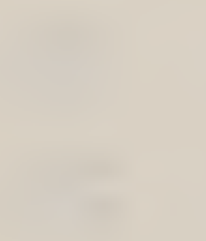 & . & $\begin{array}{l}10 \\
10 \\
10 \\
10 \\
10\end{array}$ & & & $\begin{array}{c}10 \\
9 \\
\text { Missing } \\
10 \\
\text { Missing }\end{array}$ \\
\hline 67 & $\begin{array}{l}1 \\
2 \\
3\end{array}$ & & & $\begin{array}{l}10 \\
10 \\
10\end{array}$ & & & \\
\hline 68 & $\begin{array}{l}1 \\
2 \\
3\end{array}$ & & n & $\begin{array}{l}10 \\
10 \\
10\end{array}$ & & & \\
\hline 69 & $\begin{array}{l}1 \\
2 \\
3\end{array}$ & & & $\begin{array}{l}10 \\
10 \\
10\end{array}$ & & & \\
\hline
\end{tabular}


Table 4 (continued)

\begin{tabular}{|c|c|c|c|c|c|c|c|}
\hline System & $\begin{array}{c}\text { Exposure } \\
\text { Time } \\
\text { (years) }\end{array}$ & $\begin{array}{l}\text { Exposed } \\
\text { Window }\end{array}$ & $\begin{array}{l}\text { Exposed } \\
\text { Ring }\end{array}$ & $\begin{array}{l}\text { Under } \\
\text { Jacket }\end{array}$ & $\begin{array}{l}1 / 2 \text { Inch } \\
\text { Window }\end{array}$ & $\begin{array}{l}\text { 1/2 Inch } \\
\text { Ring }\end{array}$ & $\begin{array}{l}\text { Copper } \\
\text { Cathode }\end{array}$ \\
\hline 70 & $\begin{array}{l}1 \\
2 \\
3\end{array}$ & & & $\begin{array}{r}10 \\
10 \\
3\end{array}$ & & & \\
\hline 73 & $\begin{array}{l}1 \\
2\end{array}$ & $\begin{array}{l}9(10 \\
4(10)\end{array}$ & $\begin{array}{l}9(10) \\
2(10)\end{array}$ & $\begin{array}{l}9(10) \\
9(10)\end{array}$ & $\begin{array}{l}9(10) \\
8(10)\end{array}$ & $\begin{array}{l}9(10) \\
8(10)\end{array}$ & \\
\hline 74 & $\begin{array}{l}1 \\
2\end{array}$ & $\begin{array}{l}2(9) \\
4(10)\end{array}$ & $\begin{array}{l}1(9) \\
2(10)\end{array}$ & $\begin{array}{l}9(10) \\
9(10)\end{array}$ & $\begin{array}{l}5(9) \\
8(10)\end{array}$ & $\begin{array}{l}3(9) \\
8(10)\end{array}$ & $\begin{array}{l}10 \\
10\end{array}$ \\
\hline 75 & $\begin{array}{l}1 \\
2\end{array}$ & $\begin{array}{r}10(10) \\
8(10)\end{array}$ & $\begin{array}{r}10(10) \\
8(10)\end{array}$ & $\begin{array}{l}10(10) \\
10(10)\end{array}$ & $\begin{array}{l}10(10) \\
10(10)\end{array}$ & $\begin{array}{l}10(10) \\
10(10)\end{array}$ & \\
\hline 76 & $\begin{array}{l}1 \\
2\end{array}$ & $\begin{array}{r}10(10) \\
8(10)\end{array}$ & $\begin{array}{c}10(10) \\
6+(10)\end{array}$ & $\begin{array}{l}10(10) \\
10(10)\end{array}$ & $\begin{array}{l}10(10) \\
10(10)\end{array}$ & $\begin{array}{l}10(10) \\
10(10)\end{array}$ & $\begin{array}{l}10 \\
10\end{array}$ \\
\hline 77 & $\begin{array}{l}1 \\
2\end{array}$ & $\begin{array}{r}10(10) \\
6(10)\end{array}$ & $\begin{array}{r}10(10) \\
6(10)\end{array}$ & $\begin{array}{l}10(10) \\
10(10)\end{array}$ & $\begin{array}{l}10(10) \\
10(10)\end{array}$ & $\begin{array}{l}10(10) \\
10(10)\end{array}$ & \\
\hline 78 & $\begin{array}{l}1 \\
2\end{array}$ & $\begin{array}{r}10(10) \\
4(10)\end{array}$ & $\begin{array}{r}10(10) \\
1(10)\end{array}$ & $\begin{array}{l}10(10) \\
10(10)\end{array}$ & $\begin{array}{l}10(10) \\
10(8)\end{array}$ & $\begin{array}{l}10(10) \\
10(8)\end{array}$ & $\begin{array}{l}10 \\
10\end{array}$ \\
\hline 79 & $\begin{array}{l}1 \\
2\end{array}$ & $\begin{array}{r}10(10) \\
9(10)\end{array}$ & $\begin{array}{r}6(10) \\
10(10)\end{array}$ & $\begin{array}{l}10(10) \\
10(10)\end{array}$ & $\begin{array}{l}10(10) \\
10(10)\end{array}$ & $\begin{array}{l}10(10) \\
10(10)\end{array}$ & \\
\hline 80 & $\begin{array}{l}1 \\
2\end{array}$ & $\begin{array}{c}10(10) \\
4(4)\end{array}$ & $\begin{array}{l}5(6) \\
4(4)\end{array}$ & $\begin{array}{r}9(10) \\
10(10)\end{array}$ & $\begin{array}{l}10(10) \\
10(5)\end{array}$ & $\begin{array}{r}9(10) \\
10(10)\end{array}$ & $\begin{array}{l}10 \\
10\end{array}$ \\
\hline 81 & $\begin{array}{l}1 \\
2\end{array}$ & $\begin{array}{l}10(10) \\
10(10)\end{array}$ & $\begin{array}{l}10(10) \\
10(10)\end{array}$ & $\begin{array}{l}10(10) \\
10(10)\end{array}$ & $\begin{array}{l}10(10) \\
10(10)\end{array}$ & $\begin{array}{l}10(10) \\
10(10)\end{array}$ & \\
\hline 82 & $\begin{array}{l}1 \\
2\end{array}$ & $\begin{array}{l}6(10) \\
4(2)\end{array}$ & $\begin{array}{l}5(10) \\
3(5)\end{array}$ & $\begin{array}{r}10(10) \\
9(10)\end{array}$ & $\begin{array}{r}10(10) \\
8(10)\end{array}$ & $\begin{array}{r}10(10) \\
8(10)\end{array}$ & $\begin{array}{l}10 \\
10\end{array}$ \\
\hline 83 & $\begin{array}{l}1 \\
2\end{array}$ & $\begin{array}{l}10(10) \\
10(10)\end{array}$ & $\begin{array}{l}10(10) \\
10(10)\end{array}$ & $\begin{array}{l}10(10) \\
10(10)\end{array}$ & $\begin{array}{l}10(10) \\
10(10)\end{array}$ & $\begin{array}{l}10(10) \\
10(10)\end{array}$ & \\
\hline 84 & $\begin{array}{l}1 \\
2\end{array}$ & $\begin{array}{c}\text { Missing } \\
10(10)\end{array}$ & $10(10)$ & $10(10)$ & $10(10)$ & $10(10)$ & 10 \\
\hline 85 & $\begin{array}{l}1 \\
2\end{array}$ & $\begin{array}{r}9(10) \\
10(10)\end{array}$ & $\begin{array}{r}9(10) \\
10(10)\end{array}$ & $\begin{array}{l}10(10) \\
10(10)\end{array}$ & $\begin{array}{l}10(10) \\
10(10)\end{array}$ & $\begin{array}{l}10(10) \\
10(10)\end{array}$ & \\
\hline 86 & $\frac{1}{2}$ & $\begin{array}{l}5(10) \\
5(10)\end{array}$ & $\begin{array}{l}6(10) \\
5(10)\end{array}$ & $\begin{array}{l}10(10) \\
10(10)\end{array}$ & $\begin{array}{l}10(10) \\
10(10)\end{array}$ & $\begin{array}{l}10(10) \\
10(10)\end{array}$ & $\begin{array}{l}10 \\
10\end{array}$ \\
\hline
\end{tabular}


Table 4 (continued)

\begin{tabular}{|c|c|c|c|c|c|c|c|}
\hline System & $\begin{array}{c}\text { Exposure } \\
\text { Time } \\
\text { (years) }\end{array}$ & $\begin{array}{l}\text { Exposed } \\
\text { Window }\end{array}$ & $\begin{array}{l}\text { Exposed } \\
\text { Ring }\end{array}$ & $\begin{array}{l}\text { Under } \\
\text { Jacket }\end{array}$ & $\begin{array}{l}1 / 2 \text { Inch } \\
\text { Window }\end{array}$ & $\begin{array}{l}1 / 2 \text { Inch } \\
\text { Ring }\end{array}$ & $\begin{array}{l}\text { Copper } \\
\text { Cathode }\end{array}$ \\
\hline 87 & $\begin{array}{l}1 \\
2\end{array}$ & $\begin{array}{l}9(10) \\
6(10)\end{array}$ & $\begin{array}{l}9(10) \\
5(10)\end{array}$ & $\begin{array}{l}10(10) \\
10(10)\end{array}$ & $\begin{array}{l}10(10) \\
10(10)\end{array}$ & $\begin{array}{r}9(10) \\
10(10)\end{array}$ & \\
\hline 88 & $\begin{array}{l}1 \\
2\end{array}$ & $\begin{array}{l}6(10) \\
8(10)\end{array}$ & $\begin{array}{l}5(10) \\
5(10)\end{array}$ & $\begin{array}{r}8(10) \\
10(10)\end{array}$ & $\begin{array}{l}8(10) \\
8(10)\end{array}$ & $\begin{array}{r}8(10) \\
10(10)\end{array}$ & $\begin{array}{l}10 \\
10\end{array}$ \\
\hline 89 & 1 & 9 & 9 & 10 & 10 & 10 & \\
\hline 90 & 1 & 9 & 9 & 10 & 10 & 9 & 10 \\
\hline 91 & 1 & Destroyed & . & & & & \\
\hline 92 & 1 & Destroyed & & & & & \\
\hline 93 & 1 & $5(0)$ & $5(0)$ & $5(4)$ & $5(0)$ & $5(0)$ & 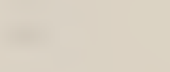 \\
\hline 94 & 1 & Destroyed & & & & & 10 \\
\hline
\end{tabular}


Table 5. Performance of Shields in Cable Specimens

Buried Up to Six Years in Hagerstown Loam (Site B)

\begin{tabular}{|c|c|c|c|c|c|c|c|}
\hline System & $\begin{array}{c}\text { Exposure } \\
\text { Time } \\
\text { (years) }\end{array}$ & $\begin{array}{l}\text { Exposed } \\
\text { Window }\end{array}$ & $\begin{array}{l}\text { Exposed } \\
\text { Ring }\end{array}$ & $\begin{array}{l}\text { Under } \\
\text { Jacket }\end{array}$ & $\begin{array}{l}1 / 2 \text { Inch } \\
\text { Window }\end{array}$ & $\begin{array}{l}\text { I/2 Inch } \\
\text { Ring }\end{array}$ & $\begin{array}{l}\text { Copper } \\
\text { Cathode }\end{array}$ \\
\hline 47 & $\begin{array}{l}1 \\
2 \\
3 \\
4 \\
5 \\
6\end{array}$ & $\begin{array}{l}10 \\
10 \\
10 \\
10 \\
10 \\
10\end{array}$ & $\begin{array}{l}10(5) \\
10 \\
10 \\
10 \\
10 \\
10\end{array}$ & $\begin{array}{l}10 \\
10 \\
10 \\
10 \\
10 \\
10\end{array}$ & $\begin{array}{l}10 \\
10(5) \\
10 \\
10 \\
10 \\
10\end{array}$ & $\begin{array}{l}10 \\
10 \\
10 \\
10 \\
10 \\
10\end{array}$ & \\
\hline 48 & $\begin{array}{l}1 \\
2 \\
3 \\
4 \\
5 \\
6\end{array}$ & $\begin{array}{l}10 \\
10 \\
10(5) \\
10(5) \\
10 \\
10(0)\end{array}$ & $\begin{array}{l}10 \\
10 \\
10 \\
10(5) \\
10 \\
10(5)\end{array}$ & $\begin{array}{l}10 \\
10 \\
10 \\
10 \\
10 \\
10\end{array}$ & $\begin{array}{l}10 \\
10 \\
10 \\
10 \\
10 \\
10(4)\end{array}$ & $\begin{array}{l}10 \\
10 \\
10 \\
10 \\
10 \\
10\end{array}$ & $\begin{array}{r}10 \\
9 \\
9 \\
9 \\
10 \\
9\end{array}$ \\
\hline 49 & $\begin{array}{l}1 \\
2 \\
3 \\
4 \\
5 \\
6\end{array}$ & $\begin{array}{l}10 \\
10 \\
10 \\
10 \\
10 \\
10\end{array}$ & $\begin{array}{l}10 \\
10 \\
10 \\
10 \\
10 \\
10\end{array}$ & $\begin{array}{l}10 \\
10 \\
10 \\
10 \\
10 \\
10\end{array}$ & $\begin{array}{l}10 \\
10 \\
10 \\
10 \\
10 \\
10\end{array}$ & $\begin{array}{l}10 \\
10 \\
10 \\
10 \\
10 \\
10\end{array}$ & \\
\hline 50 & $\begin{array}{l}1 \\
2 \\
3 \\
4 \\
5 \\
6\end{array}$ & $\begin{array}{l}10 \\
10 \\
10 \\
10 \\
10 \\
10(5)\end{array}$ & $\begin{array}{l}10 \\
10 \\
10 \\
10 \\
10 \\
10\end{array}$ & $\begin{array}{l}10 \\
10 \\
10 \\
10 \\
10 \\
10\end{array}$ & $\begin{array}{l}10 \\
10 \\
10 \\
10 \\
10 \\
10\end{array}$ & $\begin{array}{l}10 \\
10 \\
10 \\
10 \\
10 \\
10\end{array}$ & $\begin{array}{r}10 \\
9 \\
9 \\
9 \\
10 \\
9\end{array}$ \\
\hline 51 & $\begin{array}{l}1 \\
2 \\
3 \\
4 \\
5 \\
6\end{array}$ & $\begin{array}{l}10 \\
10 \\
10 \\
10 \\
10 \\
10\end{array}$ & $\begin{array}{l}10 \\
10 \\
10 \\
10 \\
10 \\
10\end{array}$ & $\begin{array}{l}10 \\
10 \\
10 \\
10 \\
10 \\
10\end{array}$ & $\begin{array}{l}10 \\
10 \\
10 \\
10 \\
10 \\
10\end{array}$ & $\begin{array}{l}10 \\
10 \\
10 \\
10 \\
10 \\
10\end{array}$ & \\
\hline 52 & $\begin{array}{l}1 \\
2 \\
3 \\
4 \\
5 \\
6\end{array}$ & $\begin{array}{l}10 \\
10 \\
10(3) \\
10(0) \\
10(4) \\
10\end{array}$ & $\begin{array}{l}10 \\
10 \\
10 \\
10(5) \\
10(5) \\
10\end{array}$ & $\begin{array}{l}10 \\
10 \\
10 \\
10(6) \\
10 \\
10\end{array}$ & $\begin{array}{l}10 \\
10 \\
10 \\
10(5) \\
10(5) \\
10\end{array}$ & $\begin{array}{l}10 \\
10 \\
10 \\
10(5) \\
10 \\
10\end{array}$ & $\begin{array}{r}9 \\
9 \\
9 \\
10 \\
10 \\
8\end{array}$ \\
\hline
\end{tabular}


Table 5 (continued)

\begin{tabular}{|c|c|c|c|c|c|c|c|}
\hline System & $\begin{array}{c}\text { Exposure } \\
\text { Time } \\
\text { (years) }\end{array}$ & $\begin{array}{l}\text { Exposed } \\
\text { Window }\end{array}$ & $\begin{array}{l}\text { Exposed } \\
\text { Ring }\end{array}$ & $\begin{array}{l}\text { Under } \\
\text { Jacket }\end{array}$ & $\begin{array}{l}\text { 1/2 Inch } \\
\text { Window }\end{array}$ & $\begin{array}{l}1 / 2 \text { Inch } \\
\text { Ring }\end{array}$ & $\begin{array}{l}\text { Copper } \\
\text { Cathode }\end{array}$ \\
\hline 55 & $\begin{array}{l}1 \\
2 \\
3 \\
4 \\
5\end{array}$ & $\begin{array}{l}\text { Not reco } \\
\text { Not reco } \\
\text { Not reco }\end{array}$ & $\begin{array}{l}\text { ered } \\
\text { iered } \\
\text { ered }\end{array}$ & $\begin{array}{l}5 \\
5\end{array}$ & & & \\
\hline 62 & $\begin{array}{l}1 \\
2 \\
3 \\
4\end{array}$ & & & $\begin{array}{l}10 \\
10 \\
10 \\
10\end{array}$ & 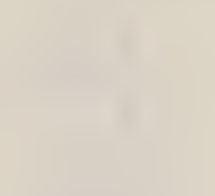 & & 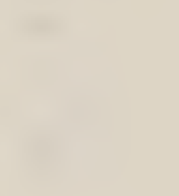 \\
\hline 63 & $\begin{array}{l}1 \\
2 \\
3 \\
4 \\
5\end{array}$ & & & $\begin{array}{l}10 \\
10 \\
10 \\
10 \\
10\end{array}$ & & & \\
\hline 64 & $\begin{array}{l}1 \\
2 \\
3 \\
4\end{array}$ & & 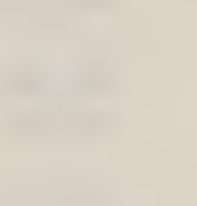 & $\begin{array}{l}10 \\
10 \\
10 \\
10\end{array}$ & & & 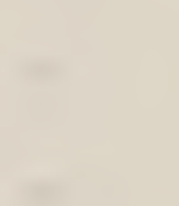 \\
\hline 65 & $\begin{array}{l}1 \\
2 \\
3 \\
4 \\
5\end{array}$ & & & $\begin{array}{l}10 \\
10 \\
10 \\
10 \\
10\end{array}$ & 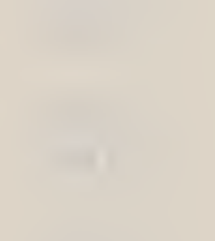 & & \\
\hline 66 & $\begin{array}{l}1 \\
2 \\
3 \\
4 \\
5\end{array}$ & & & $\begin{array}{l}10 \\
10 \\
10 \\
10 \\
10\end{array}$ & & & $\begin{array}{c}10 \\
10 \\
10 \\
\text { Missing } \\
\text { Missing }\end{array}$ \\
\hline 67 & $\begin{array}{l}1 \\
2 \\
3\end{array}$ & \multicolumn{2}{|c|}{ Not recovered } & $\begin{array}{l}10 \\
10\end{array}$ & & & \\
\hline 69 & $\begin{array}{l}1 \\
2 \\
3\end{array}$ & \multicolumn{2}{|c|}{ Not recovered } & $\begin{array}{l}10 \\
10\end{array}$ & & & \\
\hline
\end{tabular}


Table 5 (continued)

\begin{tabular}{|c|c|c|c|c|c|c|c|}
\hline System & $\begin{array}{c}\text { Exposure } \\
\text { Time } \\
\text { (years) }\end{array}$ & $\begin{array}{l}\text { Exposed } \\
\text { Window }\end{array}$ & $\begin{array}{l}\text { Exposed } \\
\text { Ring }\end{array}$ & $\begin{array}{l}\text { Under } \\
\text { Jacket }\end{array}$ & $\begin{array}{l}1 / 2 \text { Inch } \\
\text { Window }\end{array}$ & $\begin{array}{l}1 / 2 \text { Inch } \\
\text { Ring }\end{array}$ & $\begin{array}{l}\text { Copper } \\
\text { Cathode }\end{array}$ \\
\hline 70 & $\begin{array}{l}1 \\
2 \\
3\end{array}$ & & & $\begin{array}{l}10 \\
10 \\
10\end{array}$ & & & \\
\hline 73 & $\begin{array}{l}1 \\
2\end{array}$ & $\begin{array}{c}2(10) \\
10(4)\end{array}$ & $\begin{array}{c}2(10) \\
10(3)\end{array}$ & $\begin{array}{r}10(10) \\
9(10)\end{array}$ & $\begin{array}{l}9(10) \\
8(10)\end{array}$ & $\begin{array}{l}9(10) \\
8(10)\end{array}$ & \\
\hline 74 & $\begin{array}{l}1 \\
2\end{array}$ & $\begin{array}{l}0(10) \\
3(10)\end{array}$ & $\begin{array}{l}1(10) \\
2(10)\end{array}$ & $\begin{array}{l}9(10) \\
9(10)\end{array}$ & $\begin{array}{l}9(10) \\
8(10)\end{array}$ & $\begin{array}{r}5(10) \\
10(10)\end{array}$ & $\begin{array}{l}10 \\
10\end{array}$ \\
\hline 75 & $\frac{1}{2}$ & $\begin{array}{l}10(10) \\
10(10)\end{array}$ & $\begin{array}{l}10(10) \\
10(10)\end{array}$ & $\begin{array}{l}10(10) \\
10(10)\end{array}$ & $\begin{array}{l}10(10) \\
10(10)\end{array}$ & $\begin{array}{l}10(10) \\
10(10)\end{array}$ & \\
\hline 76 & $\frac{1}{2}$ & $\begin{array}{l}5(10) \\
5(10)\end{array}$ & $\begin{array}{l}5(10) \\
5(10)\end{array}$ & $\begin{array}{l}10(10) \\
10(10)\end{array}$ & $\begin{array}{l}5(10) \\
5(10)\end{array}$ & $\begin{array}{r}5(10) \\
10(10)\end{array}$ & $\begin{array}{l}10 \\
10\end{array}$ \\
\hline 77 & $\begin{array}{l}1 \\
2\end{array}$ & $\begin{array}{r}10(10) \\
5(10)\end{array}$ & $\begin{array}{r}10(10) \\
6(10)\end{array}$ & $\begin{array}{l}10(10) \\
10(10)\end{array}$ & $\begin{array}{r}10(10) \\
8(10)\end{array}$ & $\begin{array}{r}10(10) \\
8(10)\end{array}$ & \\
\hline 78 & $\frac{1}{2}$ & $\begin{array}{l}2(10) \\
1(10)\end{array}$ & $\begin{array}{l}2(10) \\
1(10)\end{array}$ & $\begin{array}{l}10(10) \\
10(10)\end{array}$ & $\begin{array}{l}9(10) \\
8(10)\end{array}$ & $\begin{array}{l}9(10) \\
8(10)\end{array}$ & $\begin{array}{l}10 \\
10\end{array}$ \\
\hline 79 & $\frac{1}{2}$ & $\begin{array}{l}6(10) \\
5(10)\end{array}$ & $\begin{array}{l}5(10) \\
5(10)\end{array}$ & $\begin{array}{r}10(10) \\
9(10)\end{array}$ & $\begin{array}{r}10(10) \\
8(10)\end{array}$ & $\begin{array}{r}10(10) \\
8(10)\end{array}$ & \\
\hline 80 & $\begin{array}{l}1 \\
2\end{array}$ & $\begin{array}{l}2(10) \\
2(6+)\end{array}$ & $\begin{array}{l}2(10) \\
1(9)\end{array}$ & $\begin{array}{l}9(10) \\
8(9)\end{array}$ & $\begin{array}{l}9(10) \\
8(10)\end{array}$ & $\begin{array}{r}10(10) \\
9(10)\end{array}$ & $\begin{array}{l}10 \\
10\end{array}$ \\
\hline 81 & $\frac{1}{2}$ & $\begin{array}{l}9(10) \\
3(10)\end{array}$ & $\begin{array}{l}5(10) \\
4(10)\end{array}$ & $\begin{array}{l}9(10) \\
9(10)\end{array}$ & $\begin{array}{l}9(10) \\
9(10)\end{array}$ & $\begin{array}{l}9(10) \\
9(10)\end{array}$ & \\
\hline 82 & $\begin{array}{l}1 \\
2\end{array}$ & $\begin{array}{l}2(10) \\
1(10)\end{array}$ & $\begin{array}{l}2(10) \\
1(10)\end{array}$ & $\begin{array}{l}9(10) \\
9(10)\end{array}$ & $\begin{array}{l}9(10) \\
8(10)\end{array}$ & $\begin{array}{l}9(10) \\
8(10)\end{array}$ & $\begin{array}{r}9 \\
10\end{array}$ \\
\hline 83 & $\frac{1}{2}$ & $\begin{array}{l}10(10) \\
10(10)\end{array}$ & $\begin{array}{l}10(10) \\
10(10)\end{array}$ & $\begin{array}{l}10(10) \\
10(10)\end{array}$ & $\begin{array}{l}10(10) \\
10(10)\end{array}$ & $\begin{array}{l}10(10) \\
10(10)\end{array}$ & \\
\hline 84 & $\begin{array}{l}1 \\
2\end{array}$ & $\begin{array}{l}.5(10) \\
6(10)\end{array}$ & $\begin{array}{l}5(10) \\
6(10)\end{array}$ & $\begin{array}{l}10(10) \\
10(10)\end{array}$ & $\begin{array}{l}10(10) \\
10(10)\end{array}$ & $\begin{array}{r}8(10) \\
10(10)\end{array}$ & $\begin{array}{l}10 \\
10\end{array}$ \\
\hline 85 & $\begin{array}{l}1 \\
2\end{array}$ & $\begin{array}{l}9(10) \\
6(10)\end{array}$ & $\begin{array}{l}4(10) \\
4(10)\end{array}$ & $\begin{array}{r}9(10) \\
10(10)\end{array}$ & $\begin{array}{c}4(10) \\
8(10)\end{array}$ & $\begin{array}{l}9(10) \\
9(10)\end{array}$ & \\
\hline 86 & $\begin{array}{l}1 \\
2\end{array}$ & $\begin{array}{l}3(9) \\
2(10)\end{array}$ & $\begin{array}{r}3(9) \\
1(10)\end{array}$ & $\begin{array}{l}10(9) \\
10(10)\end{array}$ & $\begin{array}{l}9(9) \\
8(10)\end{array}$ & $\begin{array}{c}9(9) \\
10(10)\end{array}$ & $\begin{array}{l}10 \\
10\end{array}$ \\
\hline
\end{tabular}


Table 5 (continued)

\begin{tabular}{|c|c|c|c|c|c|c|c|}
\hline System & $\begin{array}{c}\text { Exposure } \\
\text { Time } \\
\text { (years) }\end{array}$ & $\begin{array}{l}\text { Exposed } \\
\text { Window }\end{array}$ & $\begin{array}{l}\text { Exposed } \\
\text { Ring }\end{array}$ & $\begin{array}{l}\text { Under } \\
\text { Jacket }\end{array}$ & $\begin{array}{l}1 / 2 \text { Inch } \\
\text { Window }\end{array}$ & $\begin{array}{l}\text { I/2 Inch } \\
\text { Ring }\end{array}$ & $\begin{array}{l}\text { Copper } \\
\text { Cathode }\end{array}$ \\
\hline 87 & $\begin{array}{l}1 \\
2\end{array}$ & $\begin{array}{l}5(10) \\
4(10)\end{array}$ & $\begin{array}{l}5(10) \\
4(10)\end{array}$ & $\begin{array}{l}9(10) \\
9(10)\end{array}$ & $\begin{array}{l}8(10) \\
8(10)\end{array}$ & $\begin{array}{l}8(10) \\
8(10)\end{array}$ & \\
\hline 88 & $\begin{array}{l}1 \\
2\end{array}$ & $\begin{array}{l}3(10) \\
2(10)\end{array}$ & $\begin{array}{l}3(10) \\
1(10)\end{array}$ & $\begin{array}{l}8(10) \\
8(10)\end{array}$ & $\begin{array}{l}8(10) \\
8(10)\end{array}$ & $\begin{array}{l}8(10) \\
8(10)\end{array}$ & $\begin{array}{l}10 \\
10\end{array}$ \\
\hline 89 & 1 & 9 & 9 & 9 & 9 & 9 & \\
\hline 90 & 1 & 9 & 9 & 9 & 9 & 9 & 10 \\
\hline 91 & 1 & 5 & 8 & 9 & 8 & 9 & \\
\hline 92 & 1 & \multicolumn{2}{|c|}{ Destroyed } & & & & \\
\hline 93 & 1 & $9(2)$ & $9(0)$ & $9(0)$ & $9(0)$ & $9(0)$ & \\
\hline 94 & 1 & Destroy & & & & & 10 \\
\hline
\end{tabular}


Table 6. Performance of Shields in Cable Specimens

Buried Up to Six Years in Clay Soil (Site C)

\begin{tabular}{|c|c|c|c|c|c|c|c|}
\hline System & $\begin{array}{c}\text { Exposure } \\
\text { Time } \\
\text { (years) }\end{array}$ & $\begin{array}{l}\text { Exposed } \\
\text { Window }\end{array}$ & $\begin{array}{l}\text { Exposed } \\
\text { Ring }\end{array}$ & $\begin{array}{l}\text { Under } \\
\text { Jacket }\end{array}$ & $\begin{array}{l}1 / 2 \text { Inch } \\
\text { Window }\end{array}$ & $\begin{array}{l}\text { 1/2 Inch } \\
\text { Ring }\end{array}$ & $\begin{array}{l}\text { Copper } \\
\text { Cathode }\end{array}$ \\
\hline 41 & $\begin{array}{l}1 \\
2 \\
3 \\
4 \\
5 \\
6\end{array}$ & $\begin{array}{l}9 \\
10 \\
0 \\
\text { Destroyed } \\
\text { Destroyed } \\
0\end{array}$ & $\begin{array}{l}9 \\
5 \\
0 \\
\\
\\
3\end{array}$ & $\begin{array}{r}10 \\
10 \\
0\end{array}$ & $\begin{array}{r}9 \\
10 \\
1 \\
5\end{array}$ & $\begin{array}{r}9 \\
10 \\
0 \\
\\
6\end{array}$ & \\
\hline 42 & $\begin{array}{l}1 \\
2 \\
3 \\
4 \\
5 \\
6\end{array}$ & $\begin{array}{l}\text { Destroyed } \\
0 \\
\text { Destroyed } \\
\text { Destroyed } \\
\text { Destroyed } \\
\text { Destroyed }\end{array}$ & $\begin{array}{l}1 \\
1 \\
1\end{array}$ & 5 & 5 & 5 & $\begin{array}{c}10 \\
10 \\
6+ \\
9 \\
4 \\
5\end{array}$ \\
\hline 43 & $\begin{array}{l}1 \\
2 \\
3 \\
4 \\
5 \\
6\end{array}$ & $\begin{array}{l}5 \\
6 \\
0 \\
0(10) \\
0(10) \\
0(10)\end{array}$ & $\begin{array}{l}2 \\
0 \\
0 \\
1(10) \\
0(10) \\
0(10)\end{array}$ & $\begin{array}{l}6(10) \\
8 \\
0(10) \\
5(10) \\
0(10) \\
0(10)\end{array}$ & $\begin{array}{l}5(10) \\
5 \\
0 \\
2(10) \\
0(10) \\
0(10)\end{array}$ & $\begin{array}{l}2(0) \\
0(10) \\
0(10) \\
2(10) \\
0(10) \\
0(10)\end{array}$ & \\
\hline 44 & $\begin{array}{l}1 \\
2 \\
3 \\
4 \\
5 \\
6\end{array}$ & $\begin{array}{l}2 \\
0 \\
0 \\
0(10) \\
0(10) \\
0(10)\end{array}$ & $\begin{array}{l}0 \\
0 \\
0 \\
0(10) \\
0(10) \\
0(10)\end{array}$ & $\begin{array}{l}0(10) \\
0(10) \\
0(10) \\
0(10) \\
0(10) \\
0(10)\end{array}$ & $\begin{array}{l}2(10) \\
0(10) \\
0(10) \\
0(10) \\
0(10) \\
0(10)\end{array}$ & $\begin{array}{l}0(10) \\
0(10) \\
0(10) \\
0(10) \\
0(10) \\
0(10)\end{array}$ & $\begin{array}{c}10 \\
10 \\
9 \\
9 \\
\text { Missing } \\
5\end{array}$ \\
\hline 45 & $\begin{array}{l}1 \\
2 \\
3 \\
4 \\
5 \\
6\end{array}$ & $\begin{array}{l}9 \\
6 \\
0 \\
5 \\
5 \\
3\end{array}$ & $\begin{array}{l}6+ \\
6+ \\
1 \\
0 \\
1 \\
2\end{array}$ & $\begin{array}{r}5 \\
10 \\
3 \\
1 \\
2 \\
3\end{array}$ & $\begin{array}{c}6+ \\
10 \\
5 \\
0 \\
3 \\
3\end{array}$ & $\begin{array}{r}6 \\
10 \\
3 \\
0 \\
2 \\
5\end{array}$ & \\
\hline 46 & $\begin{array}{l}1 \\
2 \\
3 \\
4 \\
5 \\
6\end{array}$ & $\begin{array}{l}4 \\
5 \\
5 \\
\text { Destroyed } \\
\text { Destroyed } \\
2\end{array}$ & $\begin{array}{l}3 \\
2 \\
1 \\
1 \\
1\end{array}$ & $\begin{array}{l}4 \\
4 \\
3\end{array}$ & $\begin{array}{l}4 \\
4 \\
0\end{array}$ & $\begin{array}{l}3 \\
4 \\
1\end{array}$ & $\begin{array}{r}10 \\
10 \\
9 \\
9 \\
9 \\
9\end{array}$ \\
\hline
\end{tabular}


Table 6 (continued)

\begin{tabular}{|c|c|c|c|c|c|c|c|}
\hline System & $\begin{array}{c}\text { Exposure } \\
\text { Time } \\
\text { (years) }\end{array}$ & $\begin{array}{l}\text { Exposed } \\
\text { Window }\end{array}$ & $\begin{array}{l}\text { Exposed } \\
\text { Ring }\end{array}$ & $\begin{array}{l}\text { Under } \\
\text { Jacket }\end{array}$ & $\begin{array}{l}1 / 2 \text { Inch } \\
\text { Window }\end{array}$ & $\begin{array}{l}1 / 2 \text { Inch } \\
\text { Ring }\end{array}$ & $\begin{array}{l}\text { Copper } \\
\text { Cathode }\end{array}$ \\
\hline 47 & $\begin{array}{l}1 \\
2 \\
3 \\
4 \\
5 \\
6\end{array}$ & $\begin{array}{r}7(7) \\
9(2) \\
9(1) \\
10(5) \\
10(1) \\
10(4)\end{array}$ & $\begin{array}{l}10 \\
9(5) \\
9(9) \\
10(5) \\
10(4) \\
10(4)\end{array}$ & $\begin{array}{l}10 \\
10 \\
9(10) \\
10(5) \\
10(5) \\
10(5)\end{array}$ & $\begin{array}{l}10(5) \\
10 \\
9(10) \\
10(5) \\
10(5) \\
10(5)\end{array}$ & $\begin{array}{l}10(5) \\
10 \\
9(10) \\
10(5) \\
10(5) \\
10(5)\end{array}$ & \\
\hline 48 & $\begin{array}{l}1 \\
2 \\
3 \\
4 \\
5 \\
6\end{array}$ & $\begin{array}{l}9 \\
9(10) \\
9(1) \\
10(3) \\
10(0) \\
10(0)\end{array}$ & $\begin{array}{l}9 \\
9(10) \\
9(5) \\
10(4) \\
10(4) \\
10(4)\end{array}$ & $\begin{array}{l}9(10) \\
10 \\
10(5) \\
10(5) \\
10(4) \\
10(0)\end{array}$ & $\begin{array}{r}9(4) \\
10(0) \\
10(5) \\
10(4) \\
10(4) \\
10(0)\end{array}$ & $\begin{array}{r}9(4) \\
10(1) \\
10(5) \\
10(5) \\
10(4) \\
10(3)\end{array}$ & $\begin{array}{r}10 \\
9 \\
9 \\
9 \\
9 \\
9\end{array}$ \\
\hline 49 & $\begin{array}{l}1 \\
2 \\
3 \\
4 \\
5 \\
6\end{array}$ & $\begin{array}{c}9 \\
10(1) \\
9(1) \\
10(5) \\
\text { Not recovered } \\
10(0)\end{array}$ & $\begin{array}{l}9 \\
10 \\
9(5) \\
9(5) \\
10(5)\end{array}$ & $\begin{array}{l}9 \\
10 \\
10(9) \\
10(5) \\
10(3)\end{array}$ & $\begin{array}{c}9 \\
10(6) \\
10(9) \\
10(5) \\
10(5)\end{array}$ & $\begin{array}{l}9 \\
10(1) \\
10(9) \\
10(5) \\
10(5)\end{array}$ & \\
\hline 50 & $\begin{array}{l}1 \\
2 \\
3 \\
4 \\
5 \\
6\end{array}$ & $\begin{array}{r}9(1) \\
10(1) \\
10(1) \\
5(0) \\
10(0) \\
10(0)\end{array}$ & $\begin{array}{l}9 \\
10(4) \\
10(4) \\
9(0) \\
10(5) \\
10(0)\end{array}$ & $\begin{array}{l}9(8) \\
10(5) \\
10(2) \\
10(0) \\
10(2) \\
10(0)\end{array}$ & $\begin{array}{r}9(2) \\
10(1) \\
10(3) \\
10(0) \\
10(0) \\
10(0)\end{array}$ & $\begin{array}{l}9(2) \\
10(5) \\
10(5) \\
10(0) \\
10(5) \\
10(0)\end{array}$ & $\begin{array}{c}10 \\
9 \\
9 \\
9 \\
9 \\
\text { Missing }\end{array}$ \\
\hline 51 & $\begin{array}{l}1 \\
2 \\
3 \\
4 \\
5 \\
6\end{array}$ & $\begin{array}{r}10(5) \\
10(2) \\
10(0) \\
6(0) \\
10(5) \\
10(0)\end{array}$ & $\begin{array}{r}9(5) \\
10(5) \\
10(0) \\
10(5) \\
10(3) \\
10(0)\end{array}$ & $\begin{array}{l}10 \\
10(5) \\
10(0) \\
6(0) \\
10(4) \\
10(0)\end{array}$ & $\begin{array}{l}10(2) \\
10(5) \\
10(0) \\
10(0) \\
10(4) \\
10(0)\end{array}$ & $\begin{array}{r}10(4) \\
10(5) \\
9(0) \\
10(5) \\
10(5) \\
10(0)\end{array}$ & \\
\hline 52 & $\begin{array}{l}1 \\
2 \\
3 \\
4 \\
5 \\
6\end{array}$ & $\begin{array}{l}10 \\
10(0) \\
10(0) \\
6(0) \\
10(0) \\
10(0)\end{array}$ & $\begin{array}{l}10 \\
10(5) \\
9(0) \\
10(0) \\
10(0) \\
10(0)\end{array}$ & $\begin{array}{r}10(5) \\
10(0) \\
10(0) \\
9(0) \\
10(0) \\
10(0)\end{array}$ & $\begin{array}{r}10(1) \\
10(0) \\
9(0) \\
10(0) \\
10(0) \\
10(0)\end{array}$ & $\begin{array}{r}10(3) \\
10(5) \\
10(0) \\
5(0) \\
10(0) \\
10(0)\end{array}$ & $\begin{array}{l}9 \\
9 \\
9 \\
9 \\
9 \\
9\end{array}$ \\
\hline 53 & $\begin{array}{l}1 \\
2 \\
3 \\
4 \\
5 \\
6\end{array}$ & & & $\begin{array}{l}10 \\
10 \\
10 \\
10 \\
10 \\
10\end{array}$ & & & \\
\hline
\end{tabular}


Table 6 (continued)

\begin{tabular}{|c|c|c|c|c|c|c|c|}
\hline System & $\begin{array}{l}\text { Exposure } \\
\text { Time } \\
\text { (years) }\end{array}$ & $\begin{array}{l}\text { Exposed } \\
\text { Window }\end{array}$ & $\begin{array}{l}\text { Exposed } \\
\text { Ring }\end{array}$ & $\begin{array}{l}\text { Under } \\
\text { Jacket }\end{array}$ & $\begin{array}{l}1 / 2 \text { Inch } \\
\text { Window }\end{array}$ & $\begin{array}{l}\text { 1/2 Inch } \\
\text { Ring }\end{array}$ & $\begin{array}{l}\text { Copper } \\
\text { Cathode }\end{array}$ \\
\hline 54 & $\begin{array}{l}1 \\
2 \\
3 \\
4 \\
5 \\
6\end{array}$ & Not reco & vered & $\begin{array}{r}10 \\
10 \\
1 \\
10 \\
\\
0\end{array}$ & & & 9 \\
\hline 55 & $\begin{array}{l}1 \\
2 \\
3 \\
4 \\
5 \\
6\end{array}$ & \multicolumn{2}{|c|}{$\begin{array}{l}\text { Not recovered } \\
\text { Not recovered }\end{array}$} & $\begin{array}{l}5 \\
5 \\
2\end{array}$ & & & \\
\hline 56 & $\begin{array}{l}1 \\
2 \\
3 \\
4 \\
5 \\
6\end{array}$ & $\begin{array}{l}10 \\
10 \\
10 \\
10(2) \\
10 \\
10(5)\end{array}$ & $\begin{array}{l}10 \\
10 \\
10 \\
10 \\
10 \\
10(5)\end{array}$ & $\begin{array}{l}10 \\
10 \\
10 \\
10 \\
10 \\
10(5)\end{array}$ & $\begin{array}{l}10 \\
10 \\
10 \\
10 \\
10 \\
10(5)\end{array}$ & $\begin{array}{l}10 \\
10 \\
10 \\
10 \\
10 \\
10(5)\end{array}$ & \\
\hline 57 & $\begin{array}{l}1 \\
2 \\
3 \\
4 \\
5 \\
6\end{array}$ & $\begin{array}{l}10 \\
10(5) \\
10(5) \\
10(0) \\
10(0) \\
6(0)\end{array}$ & $\begin{array}{l}10 \\
10(5) \\
10(5) \\
10 \\
3(2) \\
10(0)\end{array}$ & $\begin{array}{l}10 \\
10 \\
10 \\
10 \\
10(0) \\
10(0)\end{array}$ & $\begin{array}{l}10 \\
10(5) \\
10 \\
10 \\
10(0) \\
9(0)\end{array}$ & $\begin{array}{l}10 \\
10(5) \\
10 \\
10 \\
10(3) \\
10(0)\end{array}$ & $\begin{array}{c}9 \\
\text { Missing } \\
\text { Missing } \\
10 \\
9 \\
9\end{array}$ \\
\hline 58 & $\begin{array}{l}1 \\
2 \\
3 \\
4 \\
5\end{array}$ & $\begin{array}{l}8(10) \\
5(10) \\
0(10) \\
0(10) \\
2(10)\end{array}$ & $\begin{array}{l}8(10) \\
5(10) \\
9(10) \\
0(10) \\
3(9)\end{array}$ & $\begin{array}{l}8(10) \\
5(10) \\
0(10) \\
0(10) \\
4(10)\end{array}$ & $\begin{array}{l}8(10) \\
8(10) \\
0(10) \\
0(10) \\
3(10)\end{array}$ & $\begin{array}{l}8(10) \\
5(10) \\
0(10) \\
0(10) \\
9(10)\end{array}$ & \\
\hline 59 & $\begin{array}{l}1 \\
2 \\
3 \\
4 \\
5\end{array}$ & $\begin{array}{l}9(10) \\
\text { Not recc } \\
5(10) \\
10 \\
0(10)\end{array}$ & $\begin{array}{c}9(10) \\
\text { vered } \\
5(10) \\
10 \\
0(5)\end{array}$ & $\begin{array}{l}9(10) \\
5(10) \\
8(10) \\
0(10)\end{array}$ & $\begin{array}{l}9(10) \\
5(10) \\
10 \\
10\end{array}$ & $\begin{array}{c}9(10) \\
5(10) \\
10 \\
0(10)\end{array}$ & $\begin{array}{c}\text { Missing } \\
10 \\
\text { Missing } \\
\text { Missing }\end{array}$ \\
\hline 60 & $\begin{array}{l}1 \\
2 \\
3 \\
4 \\
5\end{array}$ & $\begin{array}{l}8(10) 8 \\
8(10) 8 \\
8(10) 4 \\
8(10) 4 \\
9(10) 2\end{array}$ & $\begin{array}{l}8(10) 8 \\
8(10) 8 \\
8(10) 8 \\
8(10) 6 \\
9(10) 2\end{array}$ & $\begin{array}{l}8(10) 4 \\
8(10) 6 \\
8(10) 2 \\
8(10) 2 \\
9(10) 0\end{array}$ & $\begin{array}{l}8(10) 4 \\
8(10) 6 \\
8(10) 4 \\
8(10) 8 \\
9(10) 0\end{array}$ & $\begin{array}{l}8(10) 8 \\
8(10) 8 \\
8(10) 8 \\
8(10) 8 \\
9(10) 0\end{array}$ & \\
\hline
\end{tabular}


Table 6 (continued)

\begin{tabular}{cccccccc} 
System & $\begin{array}{c}\text { Exposure } \\
\text { Time } \\
\text { (years) }\end{array}$ & $\begin{array}{l}\text { Exposed } \\
\text { Window }\end{array}$ & $\begin{array}{l}\text { Exposed } \\
\text { Ring }\end{array}$ & $\begin{array}{l}\text { Under } \\
\text { Jacket }\end{array}$ & $\begin{array}{l}1 / 2 \text { Inch } \\
\text { Window }\end{array}$ & $\begin{array}{l}1 / 2 \text { Inch } \\
\text { Ring }\end{array}$ & $\begin{array}{l}\text { Copper } \\
\text { Cathode }\end{array}$ \\
\hline \multirow{2}{*}{61} & 1 & $8(10) 0$ & $10(10) 5$ & $8(10) 0$ & $8(10) 0$ & $10(10) 5$ & 10 \\
& 1 & $8(10) 2$ & $8(10) 0$ & $8(10) 0$ & $8(10) 2$ & $8(10) 0$ Missing \\
& 2 & $8(10) 0$ & $8(10) 0$ & $8(10) 0$ & $8(10) 0$ & $8(10) 0$ Missing \\
& 4 & $9(10) 0$ & $9(10) 0$ & $9(10) 0$ & $9(10) 0$ & $9(10) 0$ Missing \\
& 4 & $9(10) 0$ & $9(10) 0$ & $9(10) 0$ & $9(10) 0$ & $9(10) 0$ Missing
\end{tabular}

62

63

64

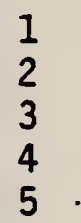

65

$\begin{array}{ll}1 & 10 \\ 2 & 10 \\ 3 & 10 \\ 4 & 10 \\ 5 & 10 \\ & 10\end{array}$

66

$\begin{array}{ll}1 & 10 \\ 2 & 10 \\ 3 & 10 \\ 4 & 10 \\ 5 & 10 \\ & 10\end{array}$

67

$\begin{array}{lll}1 & & 10 \\ 2 & & 10 \\ 3 & \text { Not recovered } & \end{array}$

68

Not recovered 
Table 6 (continued)

\begin{tabular}{|c|c|c|c|c|c|c|c|}
\hline System & $\begin{array}{c}\text { Exposure } \\
\text { Time } \\
\text { (years) }\end{array}$ & $\begin{array}{l}\text { Exposed } \\
\text { Window }\end{array}$ & $\begin{array}{l}\text { Exposed } \\
\text { Ring }\end{array}$ & $\begin{array}{l}\text { Under } \\
\text { Jacket }\end{array}$ & $\begin{array}{l}1 / 2 \text { Inch } \\
\text { Window }\end{array}$ & $\begin{array}{l}1 / 2 \text { Inch } \\
\text { Ring }\end{array}$ & $\begin{array}{l}\text { Copper } \\
\text { Cathode }\end{array}$ \\
\hline 69 & $\begin{array}{l}1 \\
2 \\
3\end{array}$ & \multicolumn{2}{|c|}{ Not recovered } & $\begin{array}{l}10 \\
10\end{array}$ & & & \\
\hline 70 & $\begin{array}{l}1 \\
2 \\
3\end{array}$ & & & $\begin{array}{l}10 \\
10 \\
10\end{array}$ & & & \\
\hline 73 & $\begin{array}{l}1 \\
2\end{array}$ & $\begin{array}{l}9(10) \\
2(10)\end{array}$ & $\begin{array}{l}2(10) \\
2(10)\end{array}$ & $\begin{array}{l}9(10) \\
8(10)\end{array}$ & $\begin{array}{l}9(10) \\
8(10)\end{array}$ & $\begin{array}{l}5(10) \\
8(10)\end{array}$ & \\
\hline 74 & $\begin{array}{l}1 \\
2\end{array}$ & $\begin{array}{l}1(10) \\
0(0)\end{array}$ & $\begin{array}{l}1(8) \\
0(3)\end{array}$ & $\begin{array}{l}9(10) \\
9(10)\end{array}$ & $\begin{array}{l}3(10) \\
8(8)\end{array}$ & $\begin{array}{l}2(10) \\
8(10)\end{array}$ & ${ }_{\text {Missing }}^{10}$ \\
\hline 75 & $\begin{array}{l}1 \\
2\end{array}$ & $\begin{array}{r}10(10) \\
8(10)\end{array}$ & $\begin{array}{r}10(10) \\
8(10)\end{array}$ & $\begin{array}{r}10(10) \\
8(10)\end{array}$ & $\begin{array}{r}10(10) \\
8(10)\end{array}$ & $\begin{array}{r}10(10) \\
8(10)\end{array}$ & \\
\hline 76 & $\begin{array}{l}1 \\
2\end{array}$ & $\begin{array}{l}2(10) \\
5(10)\end{array}$ & $\begin{array}{l}2(10) \\
4(10)\end{array}$ & $\begin{array}{l}10(10) \\
10(10)\end{array}$ & $\begin{array}{l}8(10) \\
5(10)\end{array}$ & $\begin{array}{l}6(10) \\
5(10)\end{array}$ & $\begin{array}{l}10 \\
10\end{array}$ \\
\hline 77 & $\begin{array}{l}1 \\
2\end{array}$ & $\begin{array}{l}6(10) \\
5(10)\end{array}$ & $\begin{array}{r}10(10) \\
4(10)\end{array}$ & $\begin{array}{l}10(10) \\
10(10)\end{array}$ & $\begin{array}{r}10(10) \\
8(10)\end{array}$ & $\begin{array}{r}10(10) \\
8(10)\end{array}$ & \\
\hline 78 & $\begin{array}{l}1 \\
2\end{array}$ & $\begin{array}{l}2(10) \\
0(8)\end{array}$ & $\begin{array}{l}2(10) \\
0(4)\end{array}$ & $\begin{array}{r}10(10) \\
8(10)\end{array}$ & $\begin{array}{l}9(10) \\
1(10)\end{array}$ & $\begin{array}{r}10(10) \\
0(10)\end{array}$ & $\begin{array}{l}10 \\
10\end{array}$ \\
\hline 79 & $\frac{1}{2}$ & \multicolumn{2}{|c|}{$\begin{array}{l}\text { Not recovered } \\
5(10) \quad 4(10)\end{array}$} & $10(10)$ & $8(10)$ & $8(10)$ & \\
\hline 80 & $\frac{1}{2}$ & $\begin{array}{l}2(5) \\
0(0)\end{array}$ & $\begin{array}{l}2(2) \\
0(0)\end{array}$ & $\begin{array}{c}10(10) \\
8(8)\end{array}$ & $\begin{array}{c}10(10) \\
8(1)\end{array}$ & $\begin{array}{c}10(10) \\
8(3)\end{array}$ & $\begin{array}{r}9 \\
10\end{array}$ \\
\hline 81 & $\begin{array}{l}1 \\
2\end{array}$ & \multicolumn{2}{|c|}{$\begin{array}{l}9(10) \quad 6+(10) \\
\text { Not recovered }\end{array}$} & $10(10)$ & $10(10)$ & $10(10)$ & \\
\hline 82 & $\begin{array}{l}1 \\
2\end{array}$ & $\begin{array}{l}2(10) \\
0(0)\end{array}$ & $\begin{array}{l}1(5) \\
0(1)\end{array}$ & $\begin{array}{r}10(10) \\
9(10)\end{array}$ & $\begin{array}{l}9(10) \\
2(8)\end{array}$ & $\begin{array}{c}10(10) \\
4(8)\end{array}$ & $\begin{array}{l}\text { Missing } \\
10\end{array}$ \\
\hline 83 & $\begin{array}{l}1 \\
2\end{array}$ & $\begin{array}{l}10(10) \\
10(10)\end{array}$ & $\begin{array}{r}10(10) \\
6(10)\end{array}$ & $\begin{array}{l}10(10) \\
10(10)\end{array}$ & $\begin{array}{l}10(10) \\
10(10)\end{array}$ & $\begin{array}{l}10(10) \\
10(10)\end{array}$ & \\
\hline 84 & $\begin{array}{l}1 \\
2\end{array}$ & $\begin{array}{l}6(10) \\
5(10)\end{array}$ & $\begin{array}{l}6(10) \\
5(10)\end{array}$ & $\begin{array}{l}10(10) \\
10(10)\end{array}$ & $\begin{array}{l}10(10) \\
10(10)\end{array}$ & $\begin{array}{l}10(10) \\
10(10)\end{array}$ & $\begin{array}{l}10 \\
10\end{array}$ \\
\hline 85 & $\begin{array}{l}1 \\
2\end{array}$ & $\begin{array}{l}6+(10) \\
6(10)\end{array}$ & $\begin{array}{l}5(10) \\
4(10)\end{array}$ & $\begin{array}{r}9(10) \\
10(10)\end{array}$ & $\begin{array}{l}9(10) \\
8(10)\end{array}$ & $\begin{array}{l}9(10) \\
9(10)\end{array}$ & \\
\hline
\end{tabular}


Table 6 (continued)

\begin{tabular}{|c|c|c|c|c|c|c|c|}
\hline System & $\begin{array}{c}\text { Exposure } \\
\text { Time } \\
\text { (years) }\end{array}$ & $\begin{array}{l}\text { Exposed } \\
\text { Window }\end{array}$ & $\begin{array}{l}\text { Exposed } \\
\text { Ring }\end{array}$ & $\begin{array}{l}\text { Under } \\
\text { Jacket }\end{array}$ & $\begin{array}{l}1 / 2 \text { Inch } \\
\text { Window }\end{array}$ & $\begin{array}{l}\text { 1/2 Inch } \\
\text { Ring }\end{array}$ & $\begin{array}{l}\text { Copper } \\
\text { Cathode }\end{array}$ \\
\hline 86 & $\begin{array}{l}1 \\
2\end{array}$ & $\begin{array}{l}0(9) \\
1(0)\end{array}$ & $\begin{array}{l}1(0) \\
0(0)\end{array}$ & $\begin{array}{r}9(9) \\
10(0)\end{array}$ & $\begin{array}{l}9(9) \\
8(0)\end{array}$ & $\begin{array}{r}9(9) \\
10(0)\end{array}$ & $\begin{array}{l}\text { Missing } \\
\text { Missing }\end{array}$ \\
\hline 87 & $\begin{array}{l}1 \\
2\end{array}$ & $\begin{array}{l}6(10) \\
4(10)\end{array}$ & $\begin{array}{l}5(10) \\
3(10)\end{array}$ & $\begin{array}{l}9(10) \\
8(10)\end{array}$ & $\begin{array}{l}8(10) \\
8(10)\end{array}$ & $\begin{array}{l}8(10) \\
8(10)\end{array}$ & \\
\hline 88 & $\begin{array}{l}1 \\
2\end{array}$ & $\begin{array}{l}2(5) \\
1(0)\end{array}$ & $\begin{array}{l}1(10) \\
1(5)\end{array}$ & $\begin{array}{l}9(10) \\
8(10)\end{array}$ & $\begin{array}{l}0(10) \\
8(1)\end{array}$ & $\begin{array}{l}9(10) \\
8(10)\end{array}$ & $\begin{array}{l}10 \\
10\end{array}$ \\
\hline 89 & 1 & $9(9)$ & $9(9)$ & $9(9)$ & $9(9)$ & $9(9)$ & \\
\hline 90 & 1 & 9 & 9 & 9 & 9 & 9 & 10 \\
\hline 91 & 1 & 0 & 1 & 9 & 9 & 9 & \\
\hline 93 & 1 & $9(0)$ & $9(0)$ & $9(0)$ & $9(0)$ & $9(0)$ & \\
\hline
\end{tabular}


Table 7. Performance of Shields in Cable Specimens

Buried Up to Six Years in Lakewood Sand (Site D)

\begin{tabular}{|c|c|c|c|c|c|c|c|}
\hline System & $\begin{array}{c}\text { Exposure } \\
\text { Time } \\
\text { (years) }\end{array}$ & $\begin{array}{l}\text { Exposed } \\
\text { Window }\end{array}$ & $\begin{array}{l}\text { Exposed } \\
\text { Ring }\end{array}$ & $\begin{array}{l}\text { Under } \\
\text { Jacket }\end{array}$ & $\begin{array}{l}1 / 2 \text { Inch } \\
\text { Window }\end{array}$ & $\begin{array}{l}1 / 2 \text { Inch } \\
\text { Ring }\end{array}$ & $\begin{array}{l}\text { Copper } \\
\text { Cathode }\end{array}$ \\
\hline 47 & $\begin{array}{l}1 \\
2 \\
3 \\
4 \\
5 \\
6\end{array}$ & $\begin{array}{l}10 \\
10 \\
10(8) \\
10(5) \\
10(5) \\
10(5)\end{array}$ & $\begin{array}{l}10 \\
10 \\
10(8) \\
10(5) \\
10(5) \\
10(5)\end{array}$ & $\begin{array}{l}10 \\
10 \\
10 \\
10(5) \\
10(6) \\
10(5)\end{array}$ & $\begin{array}{l}10 \\
10 \\
10 \\
10(5) \\
10(5) \\
10(5)\end{array}$ & $\begin{array}{l}10 \\
10 \\
10 \\
10(5) \\
10 \\
10(5)\end{array}$ & \\
\hline 48 & $\begin{array}{l}1 \\
2 \\
3 \\
4 \\
5 \\
6\end{array}$ & $\begin{array}{c}9 \\
10(4) \\
10(4) \\
10(4) \\
10(5) \\
10(4)\end{array}$ & $\begin{array}{l}9 \\
9(10) \\
10(5) \\
10(5) \\
10(5) \\
10(5)\end{array}$ & $\begin{array}{l}9(10) \\
10 \\
10(5) \\
10 \\
10(5) \\
10(5)\end{array}$ & $\begin{array}{l}9(10) \\
10 \\
10(5) \\
10(5) \\
10(5) \\
10(5)\end{array}$ & $\begin{array}{l}9(10) \\
10 \\
10(5) \\
10(5) \\
10(5) \\
10\end{array}$ & $\begin{array}{r}10 \\
9 \\
9 \\
9 \\
10 \\
9\end{array}$ \\
\hline 49 & $\begin{array}{l}1 \\
2 \\
3 \\
4 \\
5 \\
6\end{array}$ & $\begin{array}{l}10 \\
10 \\
10(5) \\
10(5) \\
10(4) \\
10(2)\end{array}$ & $\begin{array}{l}10 \\
10 \\
10(5) \\
10(5) \\
10(5) \\
10(5)\end{array}$ & $\begin{array}{l}10 \\
10 \\
10 \\
10 \\
10 \\
10\end{array}$ & $\begin{array}{l}10 \\
10 \\
10 \\
10(6) \\
10 \\
10(5)\end{array}$ & $\begin{array}{l}10 \\
10 \\
10 \\
10 \\
10 \\
10\end{array}$ & \\
\hline 50 & $\begin{array}{l}1 \\
2 \\
3 \\
4 \\
5 \\
6\end{array}$ & $\begin{array}{l}10 \\
10(9) \\
\text { Not reco } \\
10(1) \\
10(0) \\
10(0)\end{array}$ & $\begin{array}{l}10 \\
10(9) \\
\text { vered } \\
10(5) \\
10(5) \\
10(5)\end{array}$ & $\begin{array}{l}9(10) \\
10 \\
10(5) \\
10(5) \\
10\end{array}$ & $\begin{array}{l}10 \\
9(10) \\
10(5) \\
10(5) \\
10(5)\end{array}$ & $\begin{array}{l}10 \\
10 \\
10(5) \\
10(5) \\
10(5)\end{array}$ & $\begin{array}{r}10 \\
9 \\
9 \\
10 \\
9\end{array}$ \\
\hline 51 & $\begin{array}{l}1 \\
2 \\
3 \\
4 \\
5 \\
6\end{array}$ & $\begin{array}{l}10 \\
10 \\
10 \\
10 \\
10(4) \\
10(5)\end{array}$ & $\begin{array}{l}10 \\
10 \\
10(5) \\
10(6) \\
10(5) \\
10(5)\end{array}$ & $\begin{array}{l}10 \\
10 \\
10 \\
10(6) \\
10 \\
10(5)\end{array}$ & $\begin{array}{l}10 \\
10 \\
10 \\
10 \\
10 \\
10(5)\end{array}$ & $\begin{array}{l}10 \\
10 \\
10 \\
10(6) \\
10(5) \\
10(5)\end{array}$ & \\
\hline 52 & $\begin{array}{l}1 \\
2 \\
3 \\
4 \\
5 \\
6\end{array}$ & $\begin{array}{l}10 \\
10(5) \\
10(0) \\
10(5) \\
10(0) \\
10(0)\end{array}$ & $\begin{array}{l}10 \\
10(5) \\
10(3) \\
10(5) \\
10(3) \\
10\end{array}$ & $\begin{array}{l}10 \\
10(9) \\
10(6) \\
10(6) \\
10(5) \\
10\end{array}$ & $\begin{array}{l}10 \\
10(5) \\
10(5) \\
10(5) \\
10(4) \\
10\end{array}$ & $\begin{array}{l}10 \\
10(9) \\
10(3) \\
10(5) \\
10(4) \\
10\end{array}$ & $\begin{array}{r}9 \\
9 \\
9 \\
10 \\
10 \\
9\end{array}$ \\
\hline
\end{tabular}


Table 7 (continued)

\begin{tabular}{|c|c|c|c|c|c|c|c|}
\hline System & $\begin{array}{c}\text { Exposure } \\
\text { Time } \\
\text { (years) }\end{array}$ & $\begin{array}{l}\text { Exposed } \\
\text { Window }\end{array}$ & $\begin{array}{l}\text { Exposed } \\
\text { Ring }\end{array}$ & $\begin{array}{l}\text { Under } \\
\text { Jacket }\end{array}$ & $\begin{array}{l}1 / 2 \text { Inch } \\
\text { Window }\end{array}$ & $\begin{array}{l}1 / 2 \text { Inch } \\
\text { Ring }\end{array}$ & $\begin{array}{l}\text { Copper } \\
\text { Cathode }\end{array}$ \\
\hline 53 & $\begin{array}{l}1 \\
2 \\
3 \\
4 \\
5 \\
6\end{array}$ & & & $\begin{array}{l}10 \\
10 \\
10 \\
10 \\
10 \\
10\end{array}$ & & & \\
\hline 54 & $\begin{array}{l}1 \\
2 \\
3 \\
4 \\
5 \\
6\end{array}$ & & & $\begin{array}{l}10 \\
10 \\
10 \\
10 \\
10 \\
10\end{array}$ & & & $\begin{array}{l}\text { Missing } \\
\text { Missing } \\
\text { Missing } \\
\text { Missing } \\
9 \\
\text { Missing }\end{array}$ \\
\hline 55 & $\begin{array}{l}1 \\
2 \\
3 \\
4 \\
5 \\
6\end{array}$ & & & $\begin{array}{r}10 \\
10 \\
10 \\
10 \\
6 \\
6\end{array}$ & & & \\
\hline 56 & $\begin{array}{l}1 \\
2 \\
3 \\
4 \\
5\end{array}$ & $\begin{array}{l}10 \\
10 \\
10 \\
10\end{array}$ & $\begin{array}{l}10 \\
10 \\
10 \\
10\end{array}$ & $\begin{array}{l}10 \\
10 \\
10 \\
10 \\
10\end{array}$ & $\begin{array}{l}10 \\
10 \\
10 \\
10\end{array}$ & $\begin{array}{l}10 \\
10 \\
10 \\
10\end{array}$ & \\
\hline 57 & $\begin{array}{l}1 \\
2 \\
3 \\
4 \\
5\end{array}$ & $\begin{array}{l}\text { Not rec } \\
10(5) \\
10(0) \\
10(6) \\
10(0)\end{array}$ & $\begin{array}{l}\text { vered } \\
10(5) \\
10(4) \\
10(5) \\
10(4)\end{array}$ & $\begin{array}{l}10 \\
10 \\
10 \\
10(5)\end{array}$ & $\begin{array}{l}10(5) \\
10(5) \\
10 \\
10(4)\end{array}$ & $\begin{array}{l}10 \\
10(5) \\
10 \\
10(4)\end{array}$ & $\begin{array}{c}10 \\
\text { Missing } \\
10 \\
10\end{array}$ \\
\hline 62 & $\begin{array}{l}1 \\
2 \\
3 \\
4 \\
5\end{array}$ & & & $\begin{array}{r}10 \\
10 \\
10 \\
8 \\
10\end{array}$ & & & \\
\hline 63 & $\begin{array}{l}1 \\
2 \\
3 \\
4 \\
5\end{array}$ & & & $\begin{array}{l}10 \\
10 \\
10 \\
10 \\
10\end{array}$ & & & \\
\hline
\end{tabular}


Table 7 (continued)

\begin{tabular}{|c|c|c|c|c|c|c|c|}
\hline System & $\begin{array}{c}\text { Exposure } \\
\text { Time } \\
\text { (years) }\end{array}$ & $\begin{array}{l}\text { Exposed } \\
\text { Window }\end{array}$ & $\begin{array}{l}\text { Exposed } \\
\text { Ring }\end{array}$ & $\begin{array}{l}\text { Under } \\
\text { Jacket }\end{array}$ & $\begin{array}{l}1 / 2 \text { Inch } \\
\text { Window }\end{array}$ & $\begin{array}{l}1 / 2 \text { Inch } \\
\text { Ring }\end{array}$ & $\begin{array}{l}\text { Copper } \\
\text { Cathode }\end{array}$ \\
\hline 64 & $\begin{array}{l}1 \\
2 \\
3 \\
4 \\
5\end{array}$ & & & $\begin{array}{l}10 \\
10 \\
10 \\
10 \\
10\end{array}$ & & & \\
\hline 65 & $\begin{array}{l}1 \\
2 \\
3 \\
4 \\
5\end{array}$ & & . & $\begin{array}{l}10 \\
10 \\
10 \\
10 \\
10\end{array}$ & & & \\
\hline 66 & $\begin{array}{l}1 \\
2 \\
3 \\
4 \\
5\end{array}$ & & & $\begin{array}{l}10 \\
10 \\
10 \\
10 \\
10\end{array}$ & & & $\begin{array}{c}\text { Missing } \\
\text { Missing } \\
\text { Missing } \\
\text { Missing } \\
10\end{array}$ \\
\hline 67 & $\begin{array}{l}1 \\
2 \\
3\end{array}$ & Not rec & vered & $\begin{array}{l}10 \\
10\end{array}$ & & & \\
\hline 68 & $\begin{array}{l}1 \\
2 \\
3\end{array}$ & & & $\begin{array}{l}10 \\
10 \\
10\end{array}$ & & & \\
\hline 69 & $\begin{array}{l}1 \\
2 \\
3\end{array}$ & $\begin{array}{l}\text { Not rec } \\
\text { Not rec }\end{array}$ & $\begin{array}{l}\text { vered } \\
\text { vered }\end{array}$ & 10 & & & \\
\hline 70 & $\begin{array}{l}1 \\
2 \\
3\end{array}$ & & & $\begin{array}{l}10 \\
10 \\
10\end{array}$ & & & \\
\hline 73 & $\frac{1}{2}$ & $\begin{array}{l}9(10) \\
8(10\end{array}$ & $\begin{array}{l}6(10) \\
4(10)\end{array}$ & $\begin{array}{r}10(10) \\
9(10)\end{array}$ & $\begin{array}{l}9(10) \\
8(10)\end{array}$ & $\begin{array}{l}9(10) \\
8(10)\end{array}$ & \\
\hline 74 & $\begin{array}{l}1 \\
2\end{array}$ & $\begin{array}{l}5(10) \\
4(10)\end{array}$ & $\begin{array}{l}2(10) \\
4(10)\end{array}$ & $\begin{array}{l}9(10) \\
8(10)\end{array}$ & $\begin{array}{l}9(10) \\
8(10)\end{array}$ & $\begin{array}{l}4(10) \\
8(10)\end{array}$ & $\begin{array}{l}10 \\
10\end{array}$ \\
\hline 75 & $\frac{1}{2}$ & $\begin{array}{l}10(10) \\
10(10)\end{array}$ & $\begin{array}{l}10(10) \\
10(10)\end{array}$ & $\begin{array}{l}10(10) \\
10(10)\end{array}$ & $\begin{array}{l}10(10) \\
10(10)\end{array}$ & $\begin{array}{l}10(10) \\
10(10)\end{array}$ & \\
\hline 76 & $\frac{1}{2}$ & $\begin{array}{r}10(10) \\
5(10)\end{array}$ & $\begin{array}{l}6+(10) \\
6(10)\end{array}$ & $\begin{array}{l}10(10) \\
10(10)\end{array}$ & $\begin{array}{l}10(10) \\
10(10)\end{array}$ & $\begin{array}{l}10(10) \\
10(10)\end{array}$ & $\begin{array}{l}10 \\
10\end{array}$ \\
\hline
\end{tabular}


Table 7 (continued)

\begin{tabular}{|c|c|c|c|c|c|c|c|}
\hline System & $\begin{array}{c}\text { Exposure } \\
\text { Time } \\
\text { (years) }\end{array}$ & $\begin{array}{l}\text { Exposed } \\
\text { Window }\end{array}$ & $\begin{array}{l}\text { Exposed } \\
\text { Ring }\end{array}$ & $\begin{array}{l}\text { Under } \\
\text { Jacket }\end{array}$ & $\begin{array}{l}1 / 2 \text { Inch } \\
\text { Window }\end{array}$ & $\begin{array}{l}1 / 2 \text { Inch } \\
\text { Ring }\end{array}$ & $\begin{array}{l}\text { Copper } \\
\text { Cathode }\end{array}$ \\
\hline 77 & $\begin{array}{l}1 \\
2\end{array}$ & $\begin{array}{r}10(10) \\
8(10)\end{array}$ & $\begin{array}{r}10(10) \\
6(10)\end{array}$ & $\begin{array}{l}10(10) \\
10(10)\end{array}$ & $\begin{array}{r}10(10) \\
9(10)\end{array}$ & $\begin{array}{r}10(10) \\
9(10)\end{array}$ & \\
\hline 78 & $\begin{array}{l}1 \\
2\end{array}$ & $\begin{array}{l}6(10) \\
5(10)\end{array}$ & $\begin{array}{l}5(10) \\
4(10)\end{array}$ & $\begin{array}{l}10(10) \\
10(10)\end{array}$ & $\begin{array}{r}10(10) \\
5(10)\end{array}$ & $\begin{array}{l}10(10) \\
10(10)\end{array}$ & $\begin{array}{l}10 \\
10\end{array}$ \\
\hline 79 & $\begin{array}{l}1 \\
2\end{array}$ & $\begin{array}{l}6+(10) \\
8(10)\end{array}$ & $\begin{array}{l}6(10) \\
5(10)\end{array}$ & $\begin{array}{l}10(10) \\
10(10)\end{array}$ & $\begin{array}{r}10(10) \\
9(10)\end{array}$ & $\begin{array}{r}10(10) \\
9(10)\end{array}$ & \\
\hline 80 & $\begin{array}{l}1 \\
2\end{array}$ & $\begin{array}{l}8(10) \\
5(10)\end{array}$ & $\begin{array}{l}6(10) \\
4(10)\end{array}$ & $\begin{array}{l}10(10) \\
10(10)\end{array}$ & $\begin{array}{r}10(10) \\
8(10)\end{array}$ & $\begin{array}{r}10(10) \\
8(10)\end{array}$ & $\begin{array}{l}10 \\
10\end{array}$ \\
\hline 81 & $\begin{array}{l}1 \\
2\end{array}$ & $\begin{array}{l}9(10) \\
8(10)\end{array}$ & $\begin{array}{l}9(10) \\
5(10)\end{array}$ & $\begin{array}{l}10(10) \\
10(10)\end{array}$ & $\begin{array}{l}10(10) \\
10(10)\end{array}$ & $\begin{array}{l}10(10) \\
10(10)\end{array}$ & \\
\hline 82 & $\begin{array}{l}1 \\
2\end{array}$ & $\begin{array}{l}5(10) \\
4(10)\end{array}$ & $\begin{array}{l}5(10) \\
2(10)\end{array}$ & $\begin{array}{r}10(10) \\
9(10)\end{array}$ & $\begin{array}{r}10(10) \\
9(10)\end{array}$ & $\begin{array}{r}10(10) \\
9(10)\end{array}$ & $\begin{array}{l}10 \\
10\end{array}$ \\
\hline 83 & $\begin{array}{l}1 \\
2\end{array}$ & $\begin{array}{l}10(10) \\
10(10)\end{array}$ & $\begin{array}{l}10(10) \\
10(10)\end{array}$ & $\begin{array}{l}10(10) \\
10(10)\end{array}$ & $\begin{array}{l}10(10) \\
10(10)\end{array}$ & $\begin{array}{l}10(10) \\
10(10)\end{array}$ & \\
\hline 84 & $\frac{1}{2}$ & $\begin{array}{r}10(10) \\
5(10)\end{array}$ & $\begin{array}{c}10(6) \\
5(10)\end{array}$ & $\begin{array}{l}10(10) \\
10(10)\end{array}$ & $\begin{array}{l}10(10) \\
10(10)\end{array}$ & $\begin{array}{l}10(10) \\
10(10)\end{array}$ & $\begin{array}{l}10 \\
10\end{array}$ \\
\hline 85 & $\begin{array}{l}1 \\
2\end{array}$ & $\begin{array}{r}10(10) \\
7(10)\end{array}$ & $\begin{array}{r}10(10) \\
5(10)\end{array}$ & $\begin{array}{l}10(10) \\
10(10)\end{array}$ & $\begin{array}{l}10(10) \\
10(10)\end{array}$ & $\begin{array}{l}10(10) \\
10(10)\end{array}$ & \\
\hline 86 & $\begin{array}{l}1 \\
2\end{array}$ & $\begin{array}{l}5(10) \\
4(10)\end{array}$ & $\begin{array}{l}5(10) \\
4(10)\end{array}$ & $\begin{array}{l}10(10) \\
10(10)\end{array}$ & $\begin{array}{r}10(10) \\
8(10)\end{array}$ & $\begin{array}{l}10(10) \\
10(10)\end{array}$ & $\begin{array}{l}10 \\
10\end{array}$ \\
\hline 87 & $\begin{array}{l}1 \\
2\end{array}$ & $\begin{array}{l}7(10) \\
5(10)\end{array}$ & $\begin{array}{l}7(10) \\
5(10)\end{array}$ & $\begin{array}{l}9(10) \\
5(10)\end{array}$ & $\begin{array}{l}7(10) \\
8(10)\end{array}$ & $\begin{array}{l}8(10) \\
8(10)\end{array}$ & \\
\hline 88 & $\begin{array}{l}1 \\
2\end{array}$ & $\begin{array}{l}6(10) \\
2(10)\end{array}$ & $\begin{array}{l}5(10) \\
3(10)\end{array}$ & $\begin{array}{l}8(10) \\
8(10)\end{array}$ & $\begin{array}{l}8(10) \\
8(10)\end{array}$ & $\begin{array}{l}8(10) \\
8(10)\end{array}$ & $\begin{array}{l}10 \\
10\end{array}$ \\
\hline 89 & 1 & 10 & 9 & 9 & 10 & 10 & \\
\hline 90 & 1 & 9 & 9 & 9 & 9 & 10 & 10 \\
\hline 91 & 1 & $9(9)$ & $6(9)$ & $9(9)$ & $9(9)$ & $9(9)$ & \\
\hline 93 & 1 & $9(0)$ & $9(0)$ & $9(0)$ & $9(0)$ & $9(0)$ & \\
\hline
\end{tabular}


Table 8. Performance of Shields in Cable Specimens

Buried Up to Five Years in Coastal Sand (Site E)

\begin{tabular}{cccccccc} 
System & $\begin{array}{c}\text { Exposure } \\
\text { Time } \\
\text { (years) }\end{array}$ & $\begin{array}{c}\text { Exposed } \\
\text { Window }\end{array}$ & $\begin{array}{l}\text { Exposed } \\
\text { Ring }\end{array}$ & $\begin{array}{l}\text { Under } \\
\text { Jacket }\end{array}$ & $\begin{array}{l}\text { 1/2 Inch } \\
\text { Window }\end{array}$ & $\begin{array}{l}1 / 2 \text { Inch } \\
\text { Ring }\end{array}$ & $\begin{array}{c}\text { Copper } \\
\text { Cathode }\end{array}$ \\
\hline \multirow{2}{*}{47} & 1 & 9 & $9(10)$ & 9 & 9 & 9 & \\
& 2 & 10 & 10 & 10 & 10 & 10 & \\
& 4 & $10(5)$ & $10(5)$ & $10(5)$ & $10(5)$ & $10(5)$ & \\
& 5 & $10(6)$ & 10 & $10(5)$ & $10(5)$ & 10 & \\
& 6 & $10(5)$ & $10(5)$ & $10(5)$ & $10(5)$ & $10(5)$ & \\
48 & 1 & 10 & 10 & $9(10)$ & $9(10)$ & $9(10)$ & 10 \\
& 2 & 10 & 10 & 10 & 10 & 10 & 9 \\
& 4 & $10(2)$ & $10(5)$ & $10(4)$ & $10(5)$ & $10(2)$ & 9 \\
& 5 & $10(0)$ & $10(5)$ & $10(5)$ & $10(4)$ & $10(4)$ & 9 \\
& 6 & $10(0)$ & $10(5)$ & $10(5)$ & $10(1)$ & $10(5)$ & 9
\end{tabular}

$49 \quad 1 \quad$ Not recovered

$\begin{array}{llllll}2 & 10 & 10 & 10 & 10 & 10 \\ 3 & 10 & 10 & 10(9) & 10(9) & 10(9) \\ 4 & 10(5) & 10(5) & 10(5) & 10(5) & 10(5) \\ 5 & 10(5) & 10(6) & 10(5) & 10(6) & 10(6) \\ 6 & 10(2) & 10 & 10(5) & 10(3) & 10(3)\end{array}$

50

$\begin{array}{rlllllr}1 & 9 & 9 & 9 & 9 & 9 & 10 \\ 2 & 10 & 10 & 10 & 10 & 10 & 9 \\ 3 & 10(1) & 10(5) & 10(5) & 10(5) & 10(5) & 9 \\ 4 & 10(5) & 10(5) & 10(5) & 10(5) & 10(5) & 10 \\ 5 & 10(5) & 10(5) & 10(5) & 10(5) & 10(5) & 9 \\ 6 & 10(5) & 10 & 10(0) & 10(5) & 10 & 9\end{array}$

51

$\begin{array}{llllll}1 & 10 & 10 & 10 & 10 & 10 \\ 2 & 10(5) & 10(5) & 10(9) & 10(9) & 10(9) \\ 3 & 10(5) & 10(5) & 10(6) & 10(5) & 10(5) \\ 4 & 10 & 10 & 10(6) & 10(6) & 10 \\ 5 & 10(2) & 10(5) & 10(5) & 10 & 10(5) \\ 6 & 10(4) & 10(4) & 10(4) & 10(4) & 10(4)\end{array}$

52

$\begin{array}{llllll}1 & 10(2) & 10(5) & 10 & 10(5) & 10(5) \\ 2 & 10(5) & 10(5) & 10(5) & 10(5) & 10(5) \\ 3 & 10(0) & 10(0) & 10(0) & 10(0) & 10(0) \\ 4 & 10(0) & 10(3) & 10(0) & 10(0) & 10(3) \\ 5 & 10(0) & 10(0) & 10(0) & 10(0) & 10(0) \\ 6 & 10(0) & 10(0) & 10(0) & 10(0) & 10(0) \\ 1 & 10 & 10 & 10 & 10 & 10 \\ 2 & 10 & 10 & 10 & 10 & 10 \\ 3 & 10 & 10 & 10 & 10 & 10 \\ 4 & 10 & 10 & 10 & 10 & 10 \\ 5 & 10 & 10 & 10 & 10 & 10 \\ 6 & 10 & 10 & 10 & 10 & 10\end{array}$


Table 8 (continued)

\begin{tabular}{|c|c|c|c|c|c|c|c|}
\hline System & $\begin{array}{c}\text { Exposure } \\
\text { Time } \\
\text { (years) }\end{array}$ & $\begin{array}{l}\text { Exposed } \\
\text { Window }\end{array}$ & $\begin{array}{l}\text { Exposed } \\
\text { Ring }\end{array}$ & $\begin{array}{l}\text { Under } \\
\text { Jacket }\end{array}$ & $\begin{array}{l}1 / 2 \text { Inch } \\
\text { Window }\end{array}$ & $\begin{array}{l}\text { 1/2 Inch } \\
\text { Ring }\end{array}$ & $\begin{array}{l}\text { Copper } \\
\text { Cathode }\end{array}$ \\
\hline 54 & $\begin{array}{l}1 \\
2 \\
3 \\
4 \\
5 \\
6\end{array}$ & & & $\begin{array}{r}10 \\
10 \\
10 \\
5 \\
10 \\
9\end{array}$ & & & $\begin{array}{c}10 \\
9 \\
9 \\
\text { Missing } \\
9 \\
9\end{array}$ \\
\hline 55 & $\begin{array}{l}1 \\
2 \\
3 \\
4 \\
5 \\
6\end{array}$ & & & $\begin{array}{l}10 \\
10 \\
10 \\
10 \\
10 \\
10\end{array}$ & & & \\
\hline 56 & $\begin{array}{l}1 \\
2 \\
3 \\
4\end{array}$ & $\begin{array}{l}10 \\
10 \\
10(5) \\
10(2)\end{array}$ & $\begin{array}{l}10 \\
10(5) \\
10\end{array}$ & $\begin{array}{l}10 \\
10 \\
10(7) \\
10\end{array}$ & $\begin{array}{l}10 \\
10 \\
10(5) \\
10(5)\end{array}$ & $\begin{array}{l}10 \\
10 \\
10(6) \\
10\end{array}$ & $\because$. \\
\hline 57 & $\begin{array}{l}1 \\
2 \\
3 \\
4\end{array}$ & $\begin{array}{l}10(4) \\
10(0) \\
10(0) \\
10(4)\end{array}$ & $\begin{array}{l}10(4) \\
10(5) \\
10(4) \\
10(4)\end{array}$ & $\begin{array}{l}10(5) \\
10 \\
10(5) \\
10(4)\end{array}$ & $\begin{array}{l}10(5) \\
10(5) \\
10(4) \\
10(4)\end{array}$ & $\begin{array}{l}10(5) \\
10(5) \\
10(4) \\
10(4)\end{array}$ & $\begin{array}{c}9 \\
10 \\
\text { Missing } \\
10\end{array}$ \\
\hline 58 & $\begin{array}{l}1 \\
2 \\
3 \\
4\end{array}$ & $\begin{array}{l}8(10) \\
5(10) \\
0(10) \\
0(10)\end{array}$ & $\begin{array}{l}8(10) \\
5(10) \\
0(10) \\
0(10)\end{array}$ & $\begin{array}{l}8(10) \\
5(10) \\
0(10) \\
0(10)\end{array}$ & $\begin{array}{l}8(10) \\
8(10) \\
0(10) \\
0(10)\end{array}$ & $\begin{array}{l}8(10) \\
5(10) \\
0(10) \\
0(10)\end{array}$ & \\
\hline 59 & $\begin{array}{l}1 \\
2 \\
3 \\
4\end{array}$ & $\begin{array}{l}5(10) \\
5(10) \\
5(10) \\
5(10)\end{array}$ & $\begin{array}{l}5(10) \\
2(10) \\
5(10) \\
3(10)\end{array}$ & $\begin{array}{l}5(10) \\
0(10) \\
5(10) \\
7(10)\end{array}$ & $\begin{array}{l}8(10) \\
2(10) \\
5(10) \\
5(10)\end{array}$ & $\begin{array}{l}8(10) \\
2(10) \\
5(10) \\
9(10)\end{array}$ & $\begin{array}{c}10 \\
\text { Missing } \\
10 \\
10\end{array}$ \\
\hline 60 & $\begin{array}{l}1 \\
2 \\
3 \\
4\end{array}$ & $\begin{array}{l}8(10) 8 \\
8(10) 8 \\
8(10) 4 \\
8(10) 4\end{array}$ & $\begin{array}{l}8(10) 8 \\
8(10) 4 \\
8(10) 5 \\
8(10) 4\end{array}$ & $\begin{array}{l}8(10) 8 \\
8(10) 5 \\
8(10) 4 \\
8(10) 0\end{array}$ & $\begin{array}{l}8(10) 8 \\
8(10) 8 \\
8(10) 4 \\
8(10) 2\end{array}$ & $\begin{array}{l}8(10) 8 \\
8(10) 4 \\
8(10) 4 \\
8(10) 4\end{array}$ & \\
\hline 61 & $\begin{array}{l}1 \\
2 \\
3 \\
4 \\
5\end{array}$ & $\begin{array}{l}10(10) 0 \\
10(10) 2 \\
10(10) 0 \\
10(10) 0 \\
10(10) 0\end{array}$ & $\begin{array}{l}10(10) 0 \\
10(10) 0 \\
10(10) 0 \\
10(10) 0 \\
10(10) 0\end{array}$ & $\begin{array}{r}10(10) 0 \\
8(10) 0 \\
10(10) 0 \\
10(10) 0 \\
10(10) 0\end{array}$ & $\begin{array}{l}10(10) 0 \\
10(10) 3 \\
10(10) 0 \\
10(10) 0 \\
10(10) 0\end{array}$ & $\begin{array}{l}10(10) 0 \\
10(10) 2 \\
10(10) 0 \\
10(10) 0 \\
10(10) 0\end{array}$ & $\begin{array}{l}10 \\
\text { Missing } \\
10 \\
\text { Missing } \\
10\end{array}$ \\
\hline
\end{tabular}


Table 8 (continued)

\begin{tabular}{|c|c|c|c|c|c|c|c|}
\hline System & $\begin{array}{c}\text { Exposure } \\
\text { Time } \\
\text { (years) }\end{array}$ & $\begin{array}{l}\text { Exposed } \\
\text { Window }\end{array}$ & $\begin{array}{l}\text { Exposed } \\
\text { Ring }\end{array}$ & $\begin{array}{l}\text { Under } \\
\text { Jacket }\end{array}$ & $\begin{array}{l}1 / 2 \text { Inch } \\
\text { Window }\end{array}$ & $\begin{array}{l}\text { 1/2 Inch } \\
\text { Ring }\end{array}$ & $\begin{array}{l}\text { Copper } \\
\text { Cathode }\end{array}$ \\
\hline 62 & $\begin{array}{l}1 \\
2 \\
3 \\
4\end{array}$ & & & $\begin{array}{r}10 \\
10 \\
10 \\
8\end{array}$ & & & \\
\hline 63 & $\begin{array}{l}1 \\
2 \\
3 \\
4\end{array}$ & & & $\begin{array}{l}10 \\
10 \\
10 \\
10\end{array}$ & & & \\
\hline 64 & $\begin{array}{l}1 \\
2 \\
3 \\
4\end{array}$ & & . & $\begin{array}{l}10 \\
10 \\
10 \\
10\end{array}$ & & & \\
\hline 65 & $\begin{array}{l}1 \\
2 \\
3 \\
4\end{array}$ & & & $\begin{array}{l}10 \\
10 \\
10 \\
10\end{array}$ & & & \\
\hline 66 & $\begin{array}{l}1 \\
2 \\
3 \\
4\end{array}$ & & & $\begin{array}{l}10 \\
10 \\
10 \\
10\end{array}$ & & & $\begin{array}{c}10 \\
\text { Missing } \\
10 \\
\text { Missing }\end{array}$ \\
\hline 73 & 1 & $9(10)$ & $9(10)$ & $9(10)$ & $9(10)$ & $9(10)$ & \\
\hline 74 & 1 & $5(10)$ & $2(10)$ & $9(10)$ & $9(10)$ & $9(10)$ & 10 \\
\hline 75 & 1 & $10(10)$ & $10(10)$ & $10(10)$ & $10(10)$ & $10(10)$ & \\
\hline 76 & 1 & $5(10)$ & $4(10)$ & $10(10)$ & $2(10)$ & $5(10)$ & 10 \\
\hline 77 & 1 & $6(10)$ & $6(10)$ & $10(10)$ & $10(10)$ & $10(10)$ & \\
\hline 78 & 1 & $3(10)$ & $2(10)$ & $10(10)$ & $9(10)$ & $10(4)$ & Missing \\
\hline 79 & 1 & $9(10)$ & $9(10)$ & $6+(10)$ & $6+(10)$ & $9(10)$ & \\
\hline 80 & 1 & $4(10)$ & $4(10)$ & $10(10)$ & $10(10)$ & $10(10)$ & 10 \\
\hline 81 & 1 & $5(10)$ & $9(10)$ & $9(10)$ & $10(10)$ & $9(10)$ & \\
\hline 82 & 1 & $3(10)$ & $3(10)$ & $9(10)$ & $10(10)$ & $9(10)$ & 10 \\
\hline 83 & 1 & $10(10)$ & $10(10)$ & $10(10)$ & $10(10)$ & $10(10)$ & \\
\hline
\end{tabular}


Table 8 (continued)

\begin{tabular}{cccccccc} 
System & $\begin{array}{c}\text { Exposure } \\
\text { Time } \\
\text { (years) }\end{array}$ & $\begin{array}{l}\text { Exposed } \\
\text { Window }\end{array}$ & $\begin{array}{l}\text { Exposed } \\
\text { Ring }\end{array}$ & $\begin{array}{l}\text { Under } \\
\text { Jacket }\end{array}$ & $\begin{array}{l}1 / 2 \text { Inch } \\
\text { Window }\end{array}$ & $\begin{array}{l}1 / 2 \text { Inch } \\
\text { Ring }\end{array}$ & $\begin{array}{l}\text { Copper } \\
\text { Cathode }\end{array}$ \\
\hline 84 & 1 & $10(10)$ & $6(10)$ & $10(10)$ & $4(10)$ & $9(10)$ & 10 \\
85 & 1 & $9(10)$ & $6(10)$ & $10(10)$ & $10(10)$ & $10(10)$ & \\
86 & 1 & $5(9)$ & $4(4)$ & $10(9)$ & $9(9)$ & $10(9)$ & 10 \\
87 & 1 & $7(10)$ & $7(10)$ & $6(10)$ & $9(10)$ & $9(10)$ & \\
88 & 1 & $5(10)$ & $3(1)$ & $9(10)$ & $8(10)$ & $8(10)$ & 10
\end{tabular}


Table 9. Performance of Shields in Cable Specimens

Buried Up to Six Years in Tidal Marsh (Site G)

\begin{tabular}{|c|c|c|c|c|c|c|c|}
\hline System & $\begin{array}{c}\text { Exposure } \\
\text { Time } \\
\text { (years) }\end{array}$ & $\begin{array}{l}\text { Exposed } \\
\text { Window }\end{array}$ & $\begin{array}{l}\text { Exposed } \\
\text { Ring }\end{array}$ & $\begin{array}{l}\text { Under } \\
\text { Jacket }\end{array}$ & $\begin{array}{l}1 / 2 \text { Inch } \\
\text { Window }\end{array}$ & $\begin{array}{l}1 / 2 \text { Inch } \\
\text { Ring }\end{array}$ & $\begin{array}{l}\text { Copper } \\
\text { Cathode }\end{array}$ \\
\hline 41 & $\begin{array}{l}1 \\
2 \\
3 \\
4 \\
5 \\
6\end{array}$ & $\begin{array}{l}5 \\
5 \\
10 \\
\text { Destroyed } \\
\text { Destroyed } \\
\text { Destroyed }\end{array}$ & $\begin{array}{r}2 \\
5 \\
10 \\
1\end{array}$ & $\begin{array}{l}6 \\
5 \\
6+\end{array}$ & $\begin{array}{r}6 \\
5 \\
10\end{array}$ & $\begin{array}{r}6 \\
5 \\
10\end{array}$ & \\
\hline 42 & $\begin{array}{l}1 \\
2 \\
3 \\
4 \\
5 \\
6\end{array}$ & $\begin{array}{l}\text { Destroyed } \\
\text { Destroyed } \\
\text { Destroyed } \\
\text { Destroyed } \\
\text { Destroyed } \\
\text { Destroyed }\end{array}$ & d & & & & $\begin{array}{r}10 \\
10 \\
9 \\
9 \\
9 \\
9\end{array}$ \\
\hline 43 & $\begin{array}{l}1 \\
2 \\
3 \\
4 \\
5 \\
6\end{array}$ & $\begin{array}{l}5 \\
0 \\
0 \\
0(10) \\
0(10) \\
0(10)\end{array}$ & $\begin{array}{l}8 \\
0 \\
0 \\
0(10) \\
0(10) \\
0(10)\end{array}$ & $\begin{array}{l}5(10) \\
0(10) \\
0(10) \\
0(10) \\
0(10) \\
0(10)\end{array}$ & $\begin{array}{l}5(10) \\
0(10) \\
0(10) \\
0(10) \\
0(10) \\
0(10)\end{array}$ & $\begin{array}{l}6(10) \\
8 \\
0(10) \\
0(10) \\
0(10) \\
0(10)\end{array}$ & \\
\hline 44 & $\begin{array}{l}1 \\
2 \\
3 \\
4 \\
5 \\
6\end{array}$ & $\begin{array}{l}1 \\
0 \\
0 \\
0(10) \\
0(10) \\
0(10)\end{array}$ & $\begin{array}{l}1 \\
0 \\
0 \\
0(10) \\
0(10) \\
0(10)\end{array}$ & $\begin{array}{l}6(10) \\
0(10) \\
0(10) \\
0(10) \\
0(10) \\
0(10)\end{array}$ & $\begin{array}{l}1(10) \\
0(10) \\
0(10) \\
0(10) \\
0(10) \\
0(10)\end{array}$ & $\begin{array}{l}0(10) \\
0(10) \\
0(10) \\
0(10) \\
0(10) \\
0(10)\end{array}$ & $\begin{array}{c}10 \\
10 \\
9 \\
9 \\
\text { Missing } \\
\text { Missing }\end{array}$ \\
\hline 45 & $\begin{array}{l}1 \\
2 \\
3 \\
4 \\
5 \\
6\end{array}$ & $\begin{array}{c}2 \\
3 \\
0 \\
2 \\
\text { Destroyed } \\
\text { Destroyed }\end{array}$ & $\begin{array}{r}2 \\
5 \\
1 \\
\\
\\
d \\
d \\
d\end{array}$ & $\begin{array}{l}3 \\
3 \\
1 \\
2\end{array}$ & $\begin{array}{l}2 \\
4 \\
0 \\
0\end{array}$ & $\begin{array}{l}2 \\
3 \\
1 \\
2\end{array}$ & \\
\hline 46 & $\begin{array}{l}1 \\
2 \\
3 \\
4 \\
5 \\
6\end{array}$ & $\begin{array}{l}3 \\
\text { Destroyed } \\
1 \\
4 \\
\text { Destroyed } \\
\text { Destroyed }\end{array}$ & $\begin{array}{ll} & 1 \\
d & \\
& 1 \\
& 0\end{array}$ & $\begin{array}{l}4 \\
1 \\
2\end{array}$ & $\begin{array}{l}5 \\
1 \\
5\end{array}$ & $\begin{array}{l}1 \\
1 \\
2\end{array}$ & $\begin{array}{c}10 \\
10 \\
9 \\
9 \\
\text { Missing } \\
\text { Missing }\end{array}$ \\
\hline
\end{tabular}


Table 9 (continued)

\begin{tabular}{|c|c|c|c|c|c|c|c|}
\hline System & $\begin{array}{c}\text { Exposure } \\
\text { Time } \\
\text { (years) }\end{array}$ & $\begin{array}{l}\text { Exposed } \\
\text { Window }\end{array}$ & $\begin{array}{l}\text { Exposed } \\
\text { Ring }\end{array}$ & $\begin{array}{l}\text { Under } \\
\text { Jacket }\end{array}$ & $\begin{array}{l}1 / 2 \text { Inch } \\
\text { Window }\end{array}$ & $\begin{array}{l}\text { 1/2 Inch } \\
\text { Ring }\end{array}$ & $\begin{array}{l}\text { Copper } \\
\text { Cathode }\end{array}$ \\
\hline 47 & $\begin{array}{l}1 \\
2 \\
3 \\
4 \\
5 \\
6\end{array}$ & $\begin{array}{l}4 \\
6(0) \\
10(4) \\
10(0) \\
10(0) \\
10(0)\end{array}$ & $\begin{array}{l}10 \\
5 \\
10(5) \\
9(0) \\
10(1) \\
10(0)\end{array}$ & $\begin{array}{l}10 \\
10 \\
10(4) \\
5(0) \\
10(2) \\
10(0)\end{array}$ & $\begin{array}{r}6(2) \\
10(0) \\
10(5) \\
3(0) \\
10(5) \\
10(0)\end{array}$ & $\begin{array}{l}10(5) \\
10(5) \\
10(5) \\
10(0) \\
10(2) \\
10(0)\end{array}$ & \\
\hline 48 & $\begin{array}{l}1 \\
2 \\
3 \\
4 \\
5 \\
6\end{array}$ & $\begin{array}{l}6 \\
0 \\
6(0) \\
0 \\
10(0) \\
10(0)\end{array}$ & $\begin{array}{l}9 \\
9(3) \\
10(6) \\
4(0) \\
10(0) \\
10(1)\end{array}$ & $\begin{array}{l}9 \\
9(0) \\
9(6) \\
10(0) \\
10(0) \\
10(0)\end{array}$ & $\begin{array}{r}6+ \\
9(0) \\
8(0) \\
4(0) \\
10(0) \\
10(5)\end{array}$ & $\begin{array}{l}9 \\
9(0) \\
9(6) \\
9(0) \\
10(0) \\
10(1)\end{array}$ & $\begin{array}{c}10 \\
10 \\
9 \\
4 \\
9 \\
\text { Missing }\end{array}$ \\
\hline 49 & $\begin{array}{l}1 \\
2 \\
3 \\
4 \\
5 \\
6\end{array}$ & $\begin{array}{c}5 \\
10(0) \\
1(0) \\
2(0) \\
10(0) \\
0\end{array}$ & $\begin{array}{l}10 \\
10(1) \\
9(5) \\
10(4) \\
10(2) \\
6(0)\end{array}$ & $\begin{array}{r}10 \\
10(6) \\
10(0) \\
9(0) \\
10(2) \\
8(0)\end{array}$ & $\begin{array}{r}10(2) \\
10(0) \\
10(3) \\
3(0) \\
10(2) \\
4(0)\end{array}$ & $\begin{array}{l}10 \\
10(5) \\
10(5) \\
10(4) \\
10(3) \\
8(0)\end{array}$ & \\
\hline 50 & $\begin{array}{l}1 \\
2 \\
3 \\
4 \\
5 \\
6\end{array}$ & $\begin{array}{l}5 \\
0 \\
4(0) \\
6(0) \\
5(4) \\
0\end{array}$ & $\begin{array}{l}3 \\
6 \\
10(5) \\
5(0) \\
10(2) \\
10(4)\end{array}$ & $\begin{array}{l}10(0) \\
10(1) \\
10(5) \\
10(0) \\
5(3) \\
1\end{array}$ & $\begin{array}{r}6(2) \\
9(1) \\
10(0) \\
10(0) \\
5(4) \\
5(1)\end{array}$ & $\begin{array}{l}5 \\
9(1) \\
10(5) \\
10(0) \\
10(2) \\
10(4)\end{array}$ & $\begin{array}{r}10 \\
10 \\
9 \\
5 \\
9 \\
9\end{array}$ \\
\hline 51 & $\begin{array}{l}1 \\
2 \\
3 \\
4 \\
5 \\
6\end{array}$ & $\begin{array}{r}6 \\
5(0) \\
10(0) \\
2(0) \\
10(0) \\
6(0)\end{array}$ & $\begin{array}{l}10 \\
6(0) \\
9(0) \\
10(0) \\
10(0) \\
10(0)\end{array}$ & $\begin{array}{r}10(0) \\
10(0) \\
9(0) \\
5(0) \\
10(0) \\
10(0)\end{array}$ & $\begin{array}{l}10(0) \\
10(0) \\
10(0) \\
10(0) \\
10(0) \\
10(0)\end{array}$ & $\begin{array}{r}10(4) \\
5(0) \\
9(0) \\
5(4) \\
10(0) \\
10(0)\end{array}$ & \\
\hline 52 & $\begin{array}{l}1 \\
2 \\
3 \\
4 \\
5 \\
6\end{array}$ & $\begin{array}{r}10 \\
4(0) \\
10(0) \\
5(0) \\
1(0) \\
5(0)\end{array}$ & $\begin{array}{r}10 \\
9(0) \\
5(0) \\
10(0) \\
1(0) \\
5(0)\end{array}$ & $\begin{array}{r}10(0) \\
10(0) \\
10(0) \\
10(0) \\
1(0) \\
5(0)\end{array}$ & $\begin{array}{r}10(0) \\
10(0) \\
10(0) \\
10(0) \\
1(0) \\
5(0)\end{array}$ & $\begin{array}{l}10(4) \\
10(0) \\
10(0) \\
10(0) \\
1(0) \\
5(0)\end{array}$ & $\begin{array}{l}9 \\
7 \\
9 \\
9 \\
9 \\
9\end{array}$ \\
\hline 53 & $\begin{array}{l}1 \\
2 \\
3 \\
4 \\
5\end{array}$ & & & $\begin{array}{l}10 \\
10 \\
10 \\
10 \\
10\end{array}$ & & & \\
\hline
\end{tabular}


Table 9 (continued)

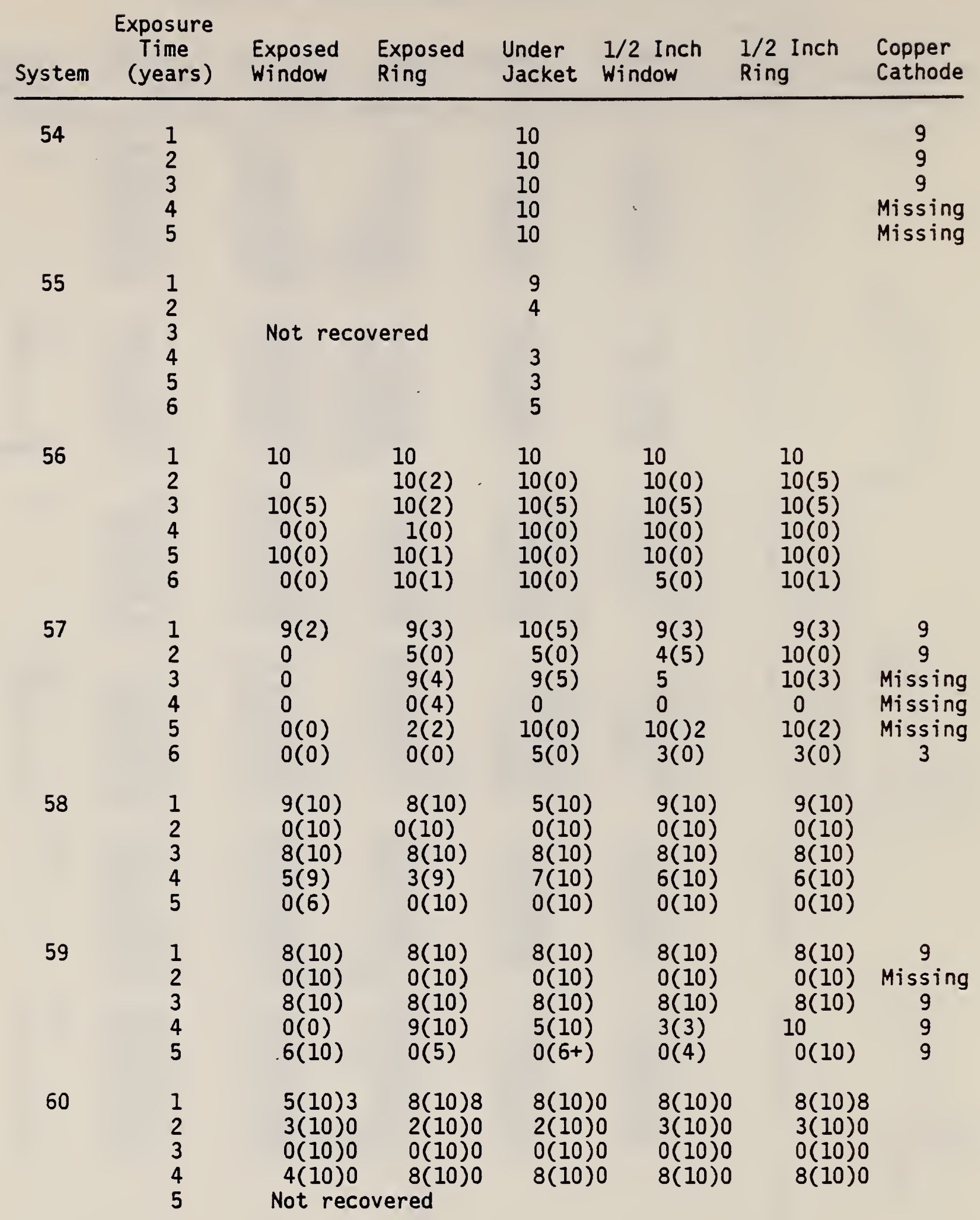


Table 9 (continued)

\begin{tabular}{|c|c|c|c|c|c|c|c|}
\hline System & $\begin{array}{c}\text { Exposure } \\
\text { Time } \\
\text { (years) }\end{array}$ & $\begin{array}{l}\text { Exposed } \\
\text { Window }\end{array}$ & $\begin{array}{l}\text { Exposed } \\
\text { Ring }\end{array}$ & $\begin{array}{l}\text { Under } \\
\text { Jacket }\end{array}$ & $\begin{array}{l}1 / 2 \text { Inch } \\
\text { Window }\end{array}$ & $\begin{array}{l}\text { 1/2 Inch } \\
\text { Ring }\end{array}$ & $\begin{array}{l}\text { Copper } \\
\text { Cathode }\end{array}$ \\
\hline 61 & $\begin{array}{l}1 \\
2 \\
3 \\
4 \\
5\end{array}$ & $\begin{array}{r}10(10) 0 \\
10(10) 0 \\
10(10) 0 \\
10(10) 0 \\
9(10) 0\end{array}$ & $\begin{array}{r}10(10) 4 \\
10(10) 0 \\
10(10) 0 \\
10(10) 0 \\
9(10) 0\end{array}$ & $\begin{array}{r}8(10) 0 \\
10(10) 0 \\
10(10) 0 \\
9(10) 0 \\
10(10) 0\end{array}$ & $\begin{array}{ll}0 & 10(10) 0 \\
0 & 10(10) 0 \\
0 & 10(10) 0 \\
0 & 10(10) 0 \\
0 & 10(10) 0\end{array}$ & $\begin{array}{l}10(10) 8 \\
10(10) 0 \\
10(10) 0 \\
10(10) 0 \\
10(10) 0\end{array}$ & $\begin{array}{l}9 \\
9 \\
9 \\
9 \\
9\end{array}$ \\
\hline 62 & $\begin{array}{l}1 \\
2 \\
3 \\
4 \\
5\end{array}$ & 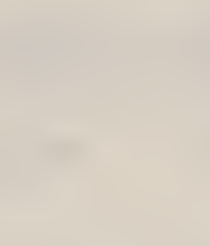 & & $\begin{array}{c}6+ \\
5 \\
10 \\
5 \\
10\end{array}$ & & & \\
\hline 63 & $\begin{array}{l}1 \\
2 \\
3 \\
4 \\
5\end{array}$ & & 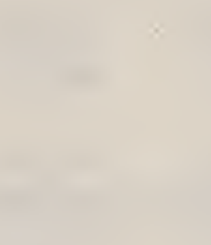 & $\begin{array}{r}10 \\
5 \\
10 \\
5 \\
5\end{array}$ & & & . \\
\hline 64 & $\begin{array}{l}1 \\
2 \\
3 \\
4 \\
5\end{array}$ & & & $\begin{array}{r}10 \\
10 \\
10 \\
5 \\
5\end{array}$ & . & & \\
\hline 65 & $\begin{array}{l}1 \\
2 \\
3 \\
4 \\
5\end{array}$ & & & $\begin{array}{l}10 \\
10 \\
10 \\
10 \\
10\end{array}$ & & & 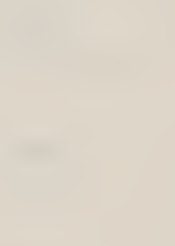 \\
\hline 73 & $\begin{array}{l}1 \\
2\end{array}$ & $\begin{array}{l}9(10) \\
0(10)\end{array}$ & $\begin{array}{l}9(10) \\
1(10)\end{array}$ & $\begin{array}{l}10(10) \\
9(10)\end{array}$ & $\begin{array}{l}9(10) \\
8(10)\end{array}$ & $\begin{array}{l}9(10) \\
8(10)\end{array}$ & \\
\hline 74 & $\frac{1}{2}$ & $\begin{array}{l}0(10) \\
0(0)\end{array}$ & $\begin{array}{l}1(5) \\
0(0)\end{array}$ & $\begin{array}{l}9(9) \\
8(0)\end{array}$ & $\begin{array}{l}9(9) \\
2(0)\end{array}$ & $\begin{array}{l}3(5) \\
0(0)\end{array}$ & $\begin{array}{l}10 \\
10\end{array}$ \\
\hline 75 & $\frac{1}{2}$ & $\begin{array}{r}10(10) \\
1(10)\end{array}$ & $\begin{array}{r}10(10) \\
5(10)\end{array}$ & $\begin{array}{l}10(10) \\
10(10)\end{array}$ & $\begin{array}{r}10(10) \\
5(10)\end{array}$ & $\begin{array}{r}10(10) \\
5(10)\end{array}$ & \\
\hline 76 & $\begin{array}{l}1 \\
2\end{array}$ & $\begin{array}{l}1(10) \\
0(10)\end{array}$ & $\begin{array}{r}10(10) \\
0(10)\end{array}$ & $\begin{array}{r}10(10) \\
5(10)\end{array}$ & $\begin{array}{r}10(10) \\
0(10)\end{array}$ & $\begin{array}{r}10(10) \\
4(10)\end{array}$ & $\begin{array}{l}10 \\
10\end{array}$ \\
\hline 77 & $\begin{array}{l}1 \\
2\end{array}$ & $\begin{array}{l}4(10) \\
0(10)\end{array}$ & $\begin{array}{l}1(10) \\
0(10)\end{array}$ & $\begin{array}{l}10(10) \\
10(10)\end{array}$ & $\begin{array}{r}10(10) \\
3(10)\end{array}$ & $\begin{array}{r}10(10) \\
0(10)\end{array}$ & \\
\hline 78 & $\frac{1}{2}$ & $\begin{array}{r}10(2) \\
0(0)\end{array}$ & $\begin{array}{r}10(0) \\
0(0)\end{array}$ & $\begin{array}{r}10(4) \\
8(4)\end{array}$ & $\begin{array}{l}9(0) \\
8(0)\end{array}$ & $\begin{array}{r}10(0) \\
3(0)\end{array}$ & $\begin{array}{l}10 \\
10\end{array}$ \\
\hline
\end{tabular}


Table 9 (continued)

\begin{tabular}{|c|c|c|c|c|c|c|c|}
\hline System & $\begin{array}{c}\text { Exposure } \\
\text { Time } \\
\text { (years) }\end{array}$ & $\begin{array}{l}\text { Exposed } \\
\text { Window }\end{array}$ & $\begin{array}{l}\text { Exposed } \\
\text { Ring }\end{array}$ & $\begin{array}{l}\text { Under } \\
\text { Jacket }\end{array}$ & $\begin{array}{l}1 / 2 \text { Inch } \\
\text { Window }\end{array}$ & $\begin{array}{l}\text { 1/2 Inch } \\
\text { Ring }\end{array}$ & $\begin{array}{l}\text { Copper } \\
\text { Cathode }\end{array}$ \\
\hline 79 & $\begin{array}{l}1 \\
2\end{array}$ & $\begin{array}{l}5(10) \\
1(3)\end{array}$ & $\begin{array}{l}1(2) \\
2(3)\end{array}$ & $\begin{array}{l}9(10) \\
8(10)\end{array}$ & $\begin{array}{l}9(10) \\
8(10)\end{array}$ & $\begin{array}{l}9(10) \\
8(10)\end{array}$ & \\
\hline 80 & $\begin{array}{l}1 \\
2\end{array}$ & $\begin{array}{l}0(0) \\
\text { Destroyed }\end{array}$ & $1(1)$ & $10(10$ & $6(10)$ & $10(10)$ & $\begin{array}{l}10 \\
10\end{array}$ \\
\hline 81 & $\frac{1}{2}$ & $\begin{array}{l}5(10) \\
4(10)\end{array}$ & $\begin{array}{l}5(10) \\
5(10)\end{array}$ & $\begin{array}{l}10(10) \\
10(10)\end{array}$ & $\begin{array}{r}10(10) \\
8(10)\end{array}$ & $\begin{array}{l}10(10) \\
10(10)\end{array}$ & \\
\hline 82 & $\begin{array}{l}1 \\
2\end{array}$ & $\begin{array}{l}1(10) \\
\text { Destroyed }\end{array}$ & $1(10)$ & $9(10)$ & $9(10)$ & $9(10)$ & $\begin{array}{l}10 \\
10\end{array}$ \\
\hline 83 & $\begin{array}{l}1 \\
2\end{array}$ & $\begin{array}{l}2(10) \\
5(3)\end{array}$ & $\begin{array}{l}5(10) \\
5(3)\end{array}$ & $\begin{array}{l}10(10) \\
10(10)\end{array}$ & $\begin{array}{c}10(10) \\
8(8)\end{array}$ & $\begin{array}{c}10(10) \\
4(8)\end{array}$ & \\
\hline 84 & $\begin{array}{l}1 \\
2\end{array}$ & $\begin{array}{l}7(10) \\
0(10)\end{array}$ & $\begin{array}{l}5(6) \\
0(10)\end{array}$ & $\begin{array}{r}10(10) \\
9(10)\end{array}$ & $\begin{array}{r}10(10) \\
2(10)\end{array}$ & $\begin{array}{r}10(10) \\
2(10)\end{array}$ & $\stackrel{9}{\text { Missing }}$ \\
\hline 85 & $\begin{array}{l}1 \\
2\end{array}$ & $\begin{array}{l}5(10) \\
\text { Destroyed }\end{array}$ & $4(1)$ & $10(10)$ & $10(10)$ & $10(10)$ & \\
\hline 86 & $\begin{array}{l}1 \\
2\end{array}$ & $\begin{array}{l}0(0) \\
\text { Destroyed }\end{array}$ & $0(1)$ & $9(5)$ & $9(3)$ & $9(2)$ & 10 \\
\hline 87 & $\begin{array}{l}1 \\
2\end{array}$ & $\begin{array}{l}6(10) \\
0(4)\end{array}$ & $\begin{array}{l}3(10) \\
0(3)\end{array}$ & $\begin{array}{l}8(10) \\
8(5)\end{array}$ & $\begin{array}{l}8(10) \\
8(5)\end{array}$ & $\begin{array}{l}8(10) \\
8(5)\end{array}$ & \\
\hline 88 & $\begin{array}{l}1 \\
2\end{array}$ & $\begin{array}{l}0(0) \\
\text { Destroyed }\end{array}$ & $0(0)$ & $8(8)$ & $8(4)$ & $8(4)$ & 9 \\
\hline 89 & 1 & 9 & 9 & 9 & 9 & 9 & \\
\hline 90 & 1 & 9 & 9 & 9 & 9 & 9 & 9 \\
\hline 91 & 1 & Destroyed & & & & & \\
\hline 92 & 1 & Destroyed & & & & & \\
\hline
\end{tabular}


NBS-114A (REV. 2-8C)

U.S. DEPT. OF COMM.

1. PUBLICATION OR

REPORT NO.

BIBLIOGRAPHIC DATA

SHEET (See in structions)

NBSIR 81-2243

2. Performing Organ. Report Nod 3. Publication Date

4. TITLE AND SUBTITLE

Corrosion Evaluation of Underground Telephone Cable Shielding Materials

\section{AUTHOR(S)}

W. F. Gerhold and J. L. Fink

6. PERFORMING ORGANIZATION (If joint or other than NBS, see instructions)

7. Contracu Grant No.

NATIONAL BUREAU OF STANDARDS

DEPARTMENT OF COMMERCE

WASHINGTON, D.C. 20234

9. SPONSORING ORGANIZATION NAME AND COMPLETE ADDRESS (Street, City, State, ZIP)

Rural Electrification Administration

Department of Agriculture

Washington, D.C. 20250

10. SUPPLEMENTARY NOTES

Document describes a computer program; SF-185, FIPS Software Summary, is attached.

11. ABSTRACT (A 200-word or less factual summary of most significant information. If document includes a significant bibliogrophy or literoture survey, mention it here)

Corrosion data is given on the performance of base and plastic coated metals intended for use as cable shields for buried telephone cable. The materials investigated on specially prepared specimens were buried for periods up to six years in six different soil environments. Metals tested included homogeneous plastic-bonded and metallurgically-bonded laminates. Some specimens were exposed bare (uncoated), while others had plastic coatings or other types of coatings on either one or both sides. Metals studied included aluminum, copper, low carbon steel and stainless steel alloys.

12. KEY WORDS (Six to twelve entries; alphabetical order; copitalize only proper names; and separate key words by semicolons) alloys; corrosion; metals; metallurgically-bonded; plastic-bonded; soils; telephone cables; underground

13. AVAILABILITY

XXnlimited

For Official Distribution. Do Not Release to NTIS

Order From Superintendent of Documents, U.S. Government Printing Office, Washington, D.C. 20402.

Order From National Technical Information Service (NTIS), Springfield, VA. 22161
14. NO. OF

PRINTED PAGES

77

15. Price

$\$ 9.50$ 
3 , 

